Prepared in cooperation with the U.S. Department of the Army

\title{
Estimates of Groundwater Age from Till and Carbonate Bedrock Hydrogeologic Units at Jefferson Proving Ground, Southeastern Indiana, 2007-08
}

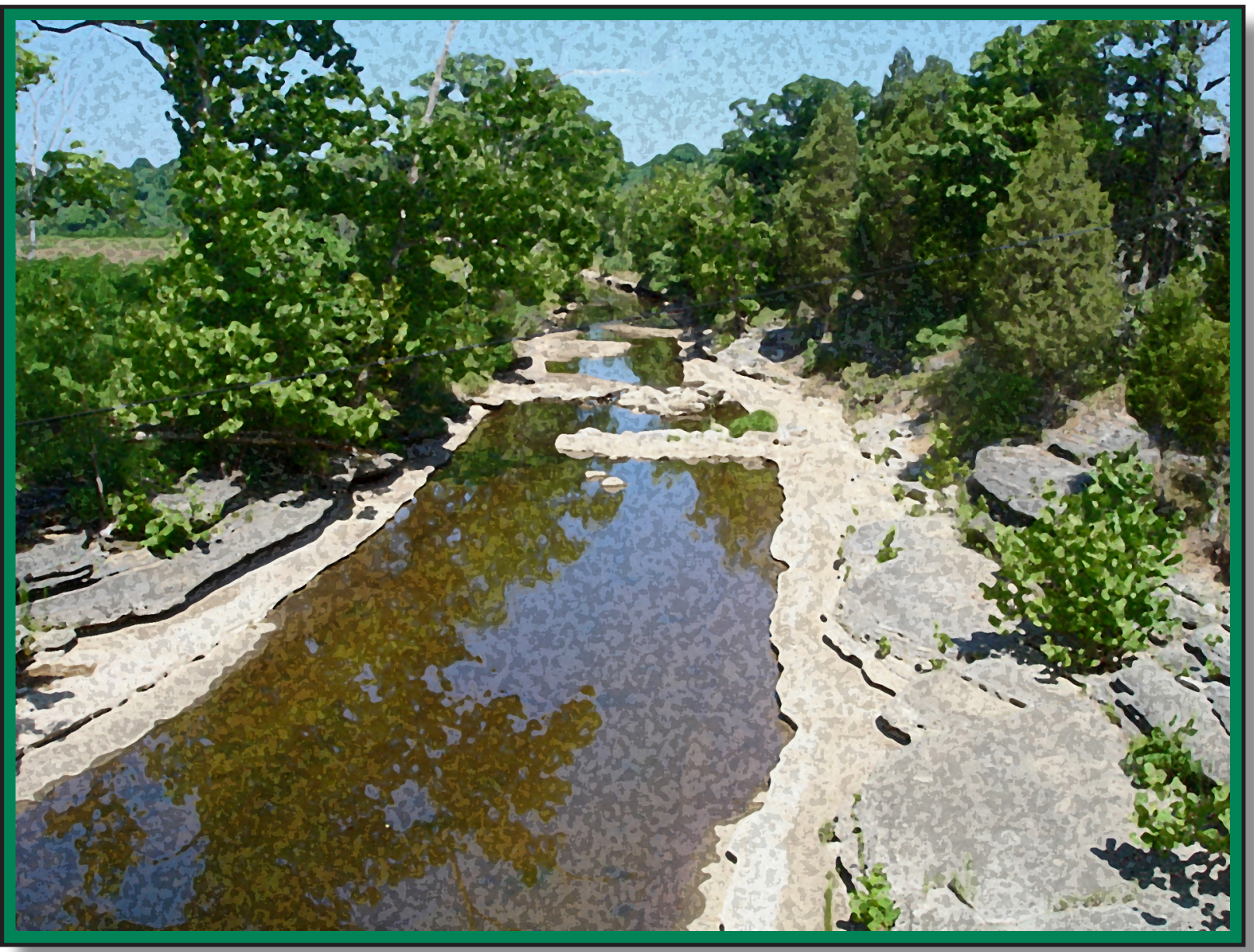

Scientific Investigations Report 2010-5178 
Front cover: Illustration adapted from a photograph of Big Creek facing west and downstream near well JPG-DU-02I at the former Jefferson Proving Ground, near Madison, Indiana (photograph by David C. Lampe, June 21, 2007). 


\section{Estimates of Groundwater Age from Till and Carbonate Bedrock Hydrogeologic Units at Jefferson Proving Ground, Southeastern Indiana, 2007-08}

By Paul M. Buszka, David C. Lampe, and Amanda L. Egler

Prepared in cooperation with the U.S. Department of the Army

Scientific Investigations Report 2010-5178 


\section{U.S. Department of the Interior \\ KEN SALAZAR, Secretary \\ U.S. Geological Survey \\ Marcia K. McNutt, Director}

U.S. Geological Survey, Reston, Virginia: 2010

This and other USGS information products are available at http://store.usgs.gov/
U.S. Geological Survey
Box 25286 , Denver Federal Center
Denver, CO 80225
To learn about the USGS and its information products visit http://www.usgs.gov/
1-888-ASK-USGS

Any use of trade, product, or firm names is for descriptive purposes only and does not imply endorsement by the U.S. Government.

Although this report is in the public domain, permission must be secured from the individual copyright owners to reproduce any copyrighted materials contained within this report.

Suggested citation:

Buszka, P.M., Lampe, D.C., and Egler, A.L., 2010, Estimates of groundwater age from till and carbonate bedrock hydrogeologic units at Jefferson Proving Ground, Southeastern Indiana, 2007-08: U.S. Geological Survey Scientific Investigations Report 2010-5178, 67 p. 


\section{Acknowledgments}

The authors and the U.S. Geological Survey appreciate the cooperation and assistance extended by the U.S. Army and Science Applications International Corporation to conduct this investigation. Paul Cloud (U.S. Army), Brooks Evens (U.S. Army Corps of Engineers, Louisville District) and Joseph Skibinski, Seth Stephenson, Jarrett McDonald, and Simon Fong (Science Applications International Corporation) provided valued assistance with project logistics, health and safety planning and activities, groundwater sampling and sharing of information from their data collection. Assistance to this project also was provided by several U.S. Geological Survey personnel: Peggy Widman and Michael Doughten (dissolved gas analysis), Julian Wayland and Eurybiades Busenberg (helium, neon, hydrogen and chlorofluorocarbon analyses) and Robert Michel (tritium analysis). 


\section{Contents}

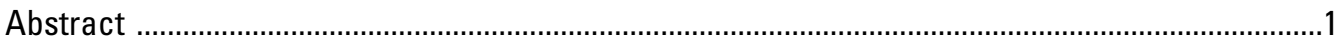

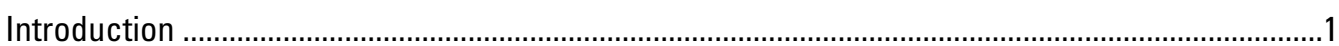

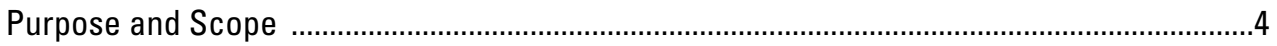

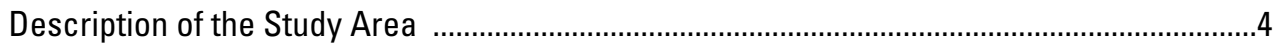

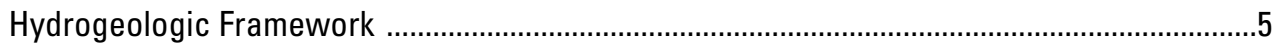

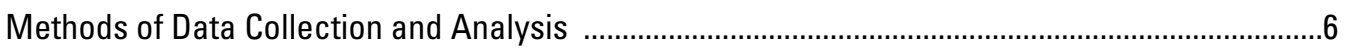

Sampling and Analyses of Groundwater Chemistry ...............................................................6

Quality-Assurance Sampling and Analyses .....................................................................

Estimates of Groundwater Age Using Tritium ...................................................................10

Estimates of Groundwater Age Using Chlorofluorocarbon Compounds .................................11

Preliminary Hydrogeologic Framework of Till and Carbonate Bedrock Hydrogeologic Units .......17

General Groundwater Chemistry and Evaluation of Oxidation-Reduction Conditions ...........21

Concentrations of Dissolved Gas and Estimated Average Recharge Temperatures .............22

Estimates of Groundwater Age from Till and Carbonate Bedrock Hydrogeologic Units ................24

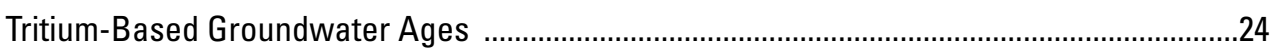

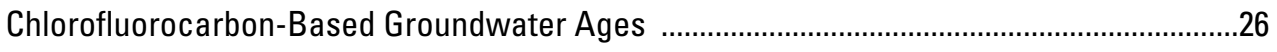

Pre-Wisconsinan Till Groundwater-Age Dates ..........................................................26

Shallow Carbonate Unit Groundwater-Age Dates .......................................................30

Deep Carbonate Unit Groundwater-Age Dates ............................................................34

Vulnerability of Groundwater to Contamination Relative to the Hydrogeologic

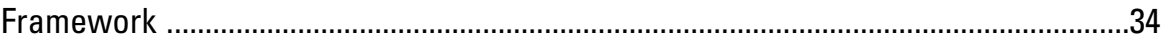

Implications and Limitations of the Age-Dating Technique ...................................................35

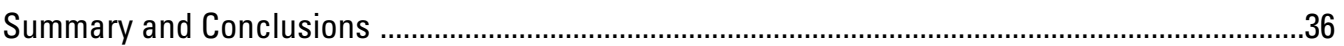

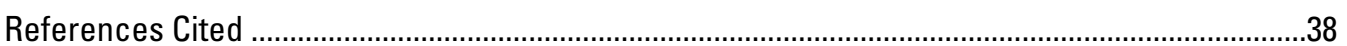

\section{Figures}

1. Study area and Depleted Uranium Impact Area, Jefferson Proving Ground, southeastern Indiana

2. Approximate extent of Depleted Uranium Impact Area relative to watersheds, monitoring wells, and a weather station, Jefferson Proving Ground, southeastern Indiana

3. Monitoring wells in the study area, Jefferson Proving Ground, southeastern Indiana

4. Average monthly concentration of tritium in precipitation in samples collected from Ottawa, Canada, 1953-2002 and monthly estimates of concentrations of tritium in precipitation for the Ohio River Basin

5. Average annual concentration of tritium in precipitation for the Ohio River Basin, 1953-2001, as corrected for decay to April 2008 when groundwater was sampled .......12

6. Atmospheric-mixing ratios of dichlorodifluoromethane (CFC-12), trichlorofluoromethane (CFC-11), and trichlorotrifluoromethane (CFC-113) for air in North America 
7. Recharge temperature grid with hypothetical concentrations of dissolved nitrogen and dissolved argon at various recharge temperatures and concentrations of excess air in water samples

8. Examples of interpreting age dates of groundwater samples using the atmosphericmixing ratios of chloroflurocarbon (CFC) compounds relative to piston-flow and binary-mixing models: A. CFC-11 and CFC-12 and B. CFC-113 and CFC-12

9. Precipitation at a Big Oaks National Wildlife Refuge weather station about 5 miles northwest of the study area at Jefferson Proving Ground, southeastern Indiana, September 2007 to September 2008

10. Altitude of the water table in the Pre-Wisconsinan till, April 7, 2008, at the Jefferson Proving Ground, southeastern Indiana

11. Altitude of groundwater levels in the shallow carbonate unit, April 7, 2008, at the Jefferson Proving Ground, southeastern Indiana

12. Altitude of groundwater levels in the deep carbonate unit, April 7, 2008, at the Jefferson Proving Ground, southeastern Indiana

13. Estimates of the average annual concentration of tritium in precipitation for the Ohio River Basin, 1953-2002, corrected for radioactive decay to April 2008, as compared with concentrations of tritium in groundwater samples in the study area at Jefferson Proving Ground, southeastern Indiana, 2008

14. Relation between atmospheric-mixing ratios of chloroflurocarbon compounds in water from wells screened in Pre-Wisconsinan till, Depleted Uranium Impact Area, Jefferson Proving Ground, southeastern Indiana, April 2008. A. CFC-11 and CFC-12; B. CFC-113 and CFC-12

15. Groundwater-age classifications of water sampled from wells screened in PreWisconsinan till, Depleted Uranium Impact Area, Jefferson Proving Ground, southeastern Indiana, April 2008

16. Relation between atmospheric-mixing ratios of chloroflurocarbon compounds in groundwater samples from the shallow carbonate unit in and near the Depleted Uranium Impact Area, Jefferson Proving Ground, southeastern Indiana, April 2008.

A. CFC-11 and CFC-12; B. CFC-113 and CFC-12

17. Groundwater-age classifications of water sampled from wells screened in the shallow carbonate unit in and near the Depleted Uranium Impact Area, Jefferson Proving Ground, southeastern Indiana, April 2008

\section{Tables}

1. Generalized hydrogeologic framework of water-bearing units sampled for this study, Jefferson Proving Ground, southeastern Indiana

2. Selected characteristics of observation wells considered for sampling at the Jefferson Proving Ground, southeastern Indiana, 2007-08

3. Number of wells sampled and not sampled for this study from each hydrogeologic unit

4. Analytical methods used for groundwater samples collected for analyses of dissolved gases and age dating at the Jefferson Proving Ground, southeastern Indiana

5. Groundwater levels measured by the U.S. Geological Survey and Science Applications International Corporation (selected dates) in wells in the PreWisconsinan till and in the shallow and deep carbonate units at the Jefferson Proving Ground, southeastern Indiana, 2007-08 
6. Vertical water-level gradients between paired shallow and deep observation wells in the Pre-Wisconsinan till and in the shallow and deep carbonate units at the Jefferson Proving Ground, southeastern Indiana, 2007-08

7. Values of field-determined water-quality parameters in groundwater samples from the Jefferson Proving Ground, southeastern Indiana, April 2008

8. Concentrations of selected dissolved gases in water samples from the Jefferson Proving Ground, southeastern Indiana, April 2008

9. Concentrations of selected dissolved gases in sequential replicate groundwater samples from the Jefferson Proving Ground, southeastern Indiana, April 2008

10. Concentrations of helium and neon in water samples from the Jefferson Proving Ground, southeastern Indiana, April 2008

11. Concentrations of tritium in groundwater samples from observation wells at the Jefferson Proving Ground, southeastern Indiana, April 2008

12. Concentrations of chlorofluorocarbon compounds and piston-flow based estimates of groundwater age for water samples from the Jefferson Proving Ground, southeastern Indiana, April 2008

13. Comparison of concentrations of tritium in groundwater samples, April 2008, to hypothetical concentrations of tritium from chlorofluorocarbon-based piston-flow model age dates and hypothetical models of binary mixtures of recharge with pre-1940 recharge, Jefferson Proving Ground, southeastern Indiana, 2008

14. Sensitivity of CFC-based age dates to changes in recharge temperature and altitude computed for a sample from well JPG-DU-030, Jefferson Proving Ground, southeastern Indiana, April 2008

15. Concentrations of chlorofluorocarbon compounds in sequential replicate groundwater samples from the Jefferson Proving Ground, southeastern Indiana, April 2008 


\section{Conversion Factors, Water-Quality Units, and Abbreviations}

\section{Inch/Pound to Metric (SI) units}

\begin{tabular}{lcl}
\hline \multicolumn{1}{c}{ Multiply } & By & \multicolumn{1}{c}{ To obtain } \\
\hline inch (in.) & Length & \\
inch (in.) & 2.54 & centimeter $(\mathrm{cm})$ \\
inch (in.) & 0.254 & millimeter $(\mathrm{mm})$ \\
foot (ft) & $2.54 \times 10^{-4}$ & micrometer $(\mu \mathrm{m})$ \\
mile (mi) & 0.3048 & meter $(\mathrm{m})$ \\
\hline & 1.609 & kilometer $(\mathrm{km})$ \\
\hline acre & Area & hectare $(\mathrm{ha})$ \\
square mile (mi $\left.{ }^{2}\right)$ & 0.4047 & hectare $(\mathrm{ha})$ \\
\hline & 259 & liter $(\mathrm{L})$ \\
\hline gallon (gal) & Volume & milliliter $(\mathrm{mL})$ or cubic \\
gallon (gal) & 3.785 & centimeter $\left(\mathrm{cm}^{3}\right)$ \\
& $3.785 \times 10^{3}$ & microliter $(\mu \mathrm{L})$ \\
\hline gallon (gal) & & kilopascal $(\mathrm{kPa})$ \\
\hline & $3.785 \times 10^{6}$ & kilopascal $(\mathrm{kPa})$ \\
\hline gallon per minute (gal/min) & Flow rate & kram $(\mathrm{g})$ \\
\hline atmosphere, standard (atm) & 0.06309 & kilogram $(\mathrm{kg})$ \\
\hline bar & Mass & \\
\hline
\end{tabular}

Temperature in degrees Fahrenheit $\left({ }^{\circ} \mathrm{F}\right)$ may be converted to degrees Celsius $\left({ }^{\circ} \mathrm{C}\right)$ as follows:

$$
{ }^{\circ} \mathrm{C}=\left({ }^{\circ} \mathrm{F}-32\right) / 1.8
$$




\section{Metric (SI) to Inch/Pound units}

\begin{tabular}{|c|c|c|}
\hline Multiply & By & To obtain \\
\hline \multicolumn{3}{|c|}{ Length } \\
\hline centimeter $(\mathrm{cm})$ & 0.3937 & inch (in.) \\
\hline millimeter (mm) & $3.937 \times 10^{-2}$ & inch (in.) \\
\hline micrometer $(\mu \mathrm{m})$ & $3.937 \times 10^{-5}$ & inch (in.) \\
\hline meter $(\mathrm{m})$ & 3.281 & foot $(\mathrm{ft})$ \\
\hline kilometer $(\mathrm{km})$ & 0.6214 & mile (mi) \\
\hline \multicolumn{3}{|c|}{ Area } \\
\hline hectare (ha) & 2.471 & acre \\
\hline hectare (ha) & 0.003861 & square mile $\left(\mathrm{mi}^{2}\right)$ \\
\hline \multicolumn{3}{|c|}{ Volume } \\
\hline liter $(\mathrm{L})$ & 0.2642 & gallon (gal) \\
\hline milliliter (mL) & $2.642 \times 10^{-4}$ & gallon (gal) \\
\hline microliter $(\mu \mathrm{L})$ & $2.642 \times 10^{-7}$ & gallon (gal) \\
\hline \multicolumn{3}{|c|}{ Flow rate } \\
\hline liter per second $(\mathrm{L} / \mathrm{s})$ & 951 & gallon per minute (gal $/ \mathrm{min})$ \\
\hline \multicolumn{3}{|c|}{ Mass } \\
\hline gram (g) & 0.03527 & ounce, avoirdupois (oz) \\
\hline kilogram (kg) & 2.205 & pound, avoirdupois (lb) \\
\hline \multicolumn{3}{|c|}{ Pressure } \\
\hline pascal $(\mathrm{Pa})$ & $9.869 \times 10^{-6}$ & atmosphere, standard (atm) \\
\hline pascal $(\mathrm{Pa})$ & $1 \times 10^{-5}$ & bar \\
\hline
\end{tabular}

Temperature in degrees Celsius $\left({ }^{\circ} \mathrm{C}\right)$ may be converted to degrees Fahrenheit $\left({ }^{\circ} \mathrm{F}\right)$ as follows:

$$
{ }^{\circ} \mathrm{F}=\left(1.8 \times{ }^{\circ} \mathrm{C}\right)+32
$$

\section{Datums}

Vertical coordinate information is referenced to the North American Vertical Datum of 1988 (NAVD 88) unless otherwise noted. Horizontal coordinate information is referenced to the North American Datum of 1983 (NAD 83), unless otherwise noted. Altitude, as used in this report, refers to distance above the vertical datum. 


\section{Abbreviated water-quality and other units used in this report}

Specific conductance is given in microsiemens per centimeter at 25 degrees Celsius $(\mu \mathrm{S} / \mathrm{cm}$ at $\left.25^{\circ} \mathrm{C}\right)$.

Concentrations of chemical constituents in water are given in milligrams per liter (mg/L), micrograms per liter $(\mu \mathrm{g} / \mathrm{L})$, or picograms per liter (pg/L). Chemical concentrations and water temperature are given in metric units.

A milligram per liter $(\mathrm{mg} / \mathrm{L})$ is a unit expressing the concentration of chemical constituents in solution as weight (milligrams) of solute per unit volume (liter) of water. For water with dissolved-solids concentrations less than $7,000 \mathrm{mg} / \mathrm{L}$, the numerical value for milligrams per liter is the same as for concentrations in parts per million.

A concentration of 1,000 micrograms per liter $(\mu \mathrm{g} / \mathrm{L})$ is equivalent to 1 milligram per liter. For water with dissolved-solids concentrations less than $7,000 \mathrm{mg} / \mathrm{L}$, the numerical value for micrograms per liter is the same as for concentrations in parts per billion.

A concentration of 1 million picograms per liter $(\mathrm{pg} / \mathrm{L}$, also picograms per kilogram of $\mathrm{pg} / \mathrm{kg})$ is equivalent to 1 milligram per liter.

The unit millimole per liter (mmol/L) expresses the concentration of chemical constituents in solution as the weight of a chemical substance, in milligrams $\left(10^{-3} \mathrm{~g}\right)$, in a liter of water, divided by the atomic weight of one atom or molecule of its composition elements, in grams (one mole). A micromole per liter ( $\mu \mathrm{mol} / \mathrm{L}$ ) is a unit expressing the concentration of chemical constituents in solution as the weight of a chemical substance, in micrograms $\left(10^{-6} \mathrm{~g}\right)$, in a liter of water, divided by the atomic weight of one atom or molecule of its composition elements, in grams. A nanomole per kilogram $(\mathrm{nmol} / \mathrm{kg})$ is a unit expressing the concentration of chemical constituents in solution as the weight of a chemical substance, in nanograms $\left(10^{-9} \mathrm{~g}\right)$, in one kilogram of water, divided by the atomic weight of one atom or molecule of its composition elements, in grams. These units are used in this report to describe concentrations of dissolved gases and constituents in a water sample.

Concentrations of the dissolved gases helium and neon are also reported in units of cc x $10^{9} / \mathbf{g}$ of water at STP; this corresponds to $10^{9}$ cubic centimeters of a dissolved gas per gram of water at standard temperature ( 25 degrees Celsius) and pressure (760 millimeters of mercury).

A Formazin Nephelometric Ratio Unit or FNRU is a unit of measure used to report the turbidity of water. Turbidity is a measure of the cloudiness of water and is measured by the amount of light that is scattered and absorbed instead of transmitted through the water by a standard light measuring device, or nephelometer.

One tritium unit (TU) is equivalent to a concentration of 3.2 picocuries per liter.

Hydraulic conductivity is given in units of feet per day. 


\section{Other abbreviations or acronyms used in this report}

\begin{tabular}{ll}
\hline $\begin{array}{c}\text { Acronym or } \\
\text { abbreviation }\end{array}$ & \multicolumn{1}{c}{ Full name of acronym or abbreviation } \\
\hline Army & U.S. Department of the Army \\
CFC & Chlorofluorocarbon compound \\
CFC-11 & Trichlorofluoromethane or $\mathrm{CFCl}_{3}$ \\
CFC-113 & Trichlorotrifluoroethane or $\mathrm{C}_{2} \mathrm{~F}_{3} \mathrm{Cl}_{3}$ \\
CFC-12 & Dichlorodifluoromethane or $\mathrm{CF}_{2} \mathrm{Cl}_{2}$ \\
CH & Methane \\
CO & Carbon dioxide \\
DU & Depleted uranium \\
FNRU & Formazin Nephelometric Ratio Units \\
He & Helium \\
JPG & Jefferson Proving Ground \\
NTU & Nephelometric Turbidity Unit \\
NWQL & National Water Quality Laboratory \\
O & Oxygen \\
pptv & Part per trillion by volume \\
PVC & Polyvinyl chloride \\
QA & Quality assurance \\
QC & Quality control \\
RPD & Relative percent difference \\
SAIC & Science Applications International Corporation \\
SC & Specific conductance \\
TU & Tritium unit \\
USEPA & U.S. Environmental Protection Agency \\
\hline
\end{tabular}




\title{
Estimates of Groundwater Age from Till and Carbonate Bedrock Hydrogeologic Units at Jefferson Proving Ground, Southeastern Indiana, 2007-08
}

\author{
By Paul M. Buszka, David C. Lampe, and Amanda L. Egler
}

\section{Abstract}

During 2007-08, the U.S. Geological Survey, in cooperation with the U.S. Department of the Army, conducted a study to evaluate the relative age of groundwater in Pre-Wisconsinan till and underlying shallow and deep carbonate bedrock units in and near an area at Jefferson Proving Ground (JPG), southeastern Indiana, which was used during 1984-94 to test fire depleted uranium (DU) penetrators. The shallow carbonate unit includes about the upper 40 feet of bedrock below the bedrock-till surface; the deeper carbonate unit includes wells completed at greater depth. Samples collected during April 2008 from 15 wells were analyzed for field water-quality parameters, dissolved gases, tritium, and chlorofluorocarbon (CFC) compounds; samples from 14 additional wells were analyzed for tritium only.

Water-level gradients in the Pre-Wisconsinan till and the shallow carbonate unit were from topographically higher areas toward Big Creek and Middle Fork Creek, and their tributaries. Vertical gradients were strongly downward from the shallow carbonate unit toward the deep carbonate unit at 3 of 4 paired wells where water levels recovered after development; indicating the general lack of flow between the two units. The lack of post development recovery of water levels at 4 other wells in the deep carbonate unit indicate that parts of that unit have no appreciable permeability.

CFC and tritium-based age dates of Pre-Wisconsinan till groundwater are consistent with infiltration of younger (typically post-1960 age) recharge that "mixes" with older recharge from less permeable or less interconnected strata. Part of the recharge to three till wells dated from the early to mid-1980s (JPG-DU-03O, JPG-DU-09O, and JPG-DU-10O). Age dates of young recharge in water from two till wells predated 1980 (JPG-DU-04O and JPG-DU-06O). Tritium-based age dates of water from seven other till wells indicated post-1972 age recharge. Most wells in the Pre-Wisconsinan till have the potential to produce groundwater that partially was recharged during or after DU penetrator testing; their water quality can indicate the presence of DU-related contaminants.

The shallow carbonate unit near Big Creek is a karst flow system that may be recharged in part from areas with smaller thicknesses of overlying till or through more permeable parts of the till. This is indicated by CFC- and tritium-based piston-flow (non-mixing) model age dates of early-1980s for water from JPG-DU-02I, similar tritium-based ages of water produced from nearby wells MW-5 and MW-11, and cave development along the creek. The CFC and tritium-based age dates indicate that water samples from JPG-DU-01I and JPG-DU-03I were best described as mixtures of post-1984 modern recharge and submodern (1953 or older) recharge. These five wells produced groundwater that was recharged, at least partially, during or after DU-penetrator testing and are within or downgradient from the DU Impact Area with respect to groundwater flow directions inferred from water-level contours. Wells with groundwater age dates that are near to or after the onset (1984) of DU penetrator testing and that have a plausible connection to a contaminant source can be used to indicate the presence or absence of contaminants from DU penetrator or DU-related corrosion products in groundwater.

Groundwater-age dates indicate that the ages of recharge sampled from shallow carbonate unit wells JPG-DU-04I, JPG-DU-05I, JPG-DU-06I, JPG-DU-09I, and JPG-DU-10D in easternmost (upgradient) and southernmost wells in the shallow carbonate unit are submodern (1953 or older) and predate the DU testing by at least 30 or more years. Water-quality data from these five wells are not likely to represent effects from DU-projectile testing or corrosion for years.

Well JPG-DU-09D in the deep carbonate unit produced groundwater samples with a submodern (1953 or older) age date. The slow recovery of water levels in most wells in the deep carbonate unit is consistent with slow rates of groundwater flow and very old groundwater ages in that unit.

\section{Introduction}

Jefferson Proving Ground (JPG), located in southeastern Indiana, is a facility of approximately $86 \mathrm{mi}^{2}$ (fig. 1) that was operated by the U.S. Department of the Army (Army) from 1940 to 1995 for testing conventional ammunition, other ordnance items, and propellant-based ammunition and weapons systems (U.S. Department of the Army, 2005). The 


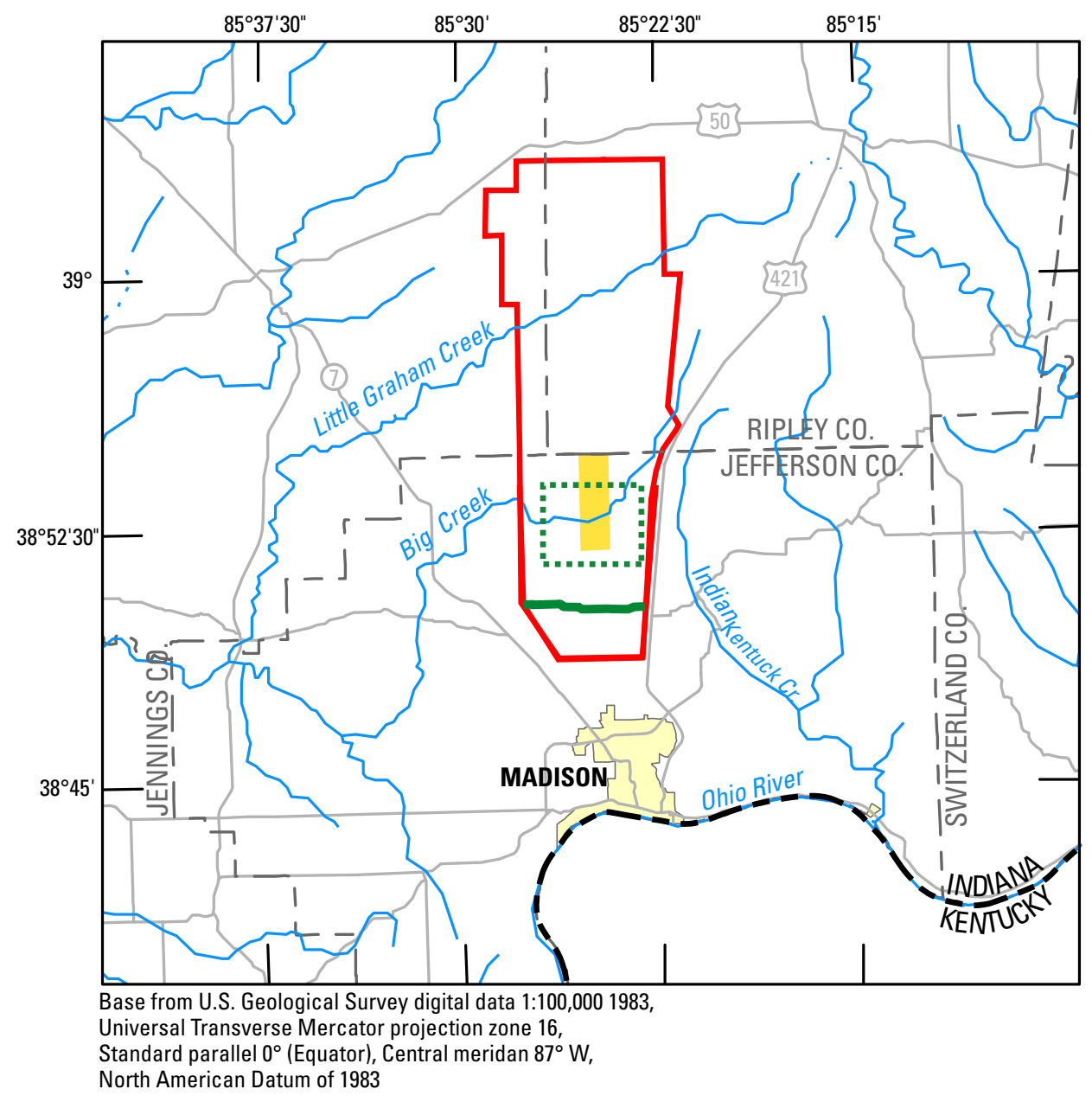

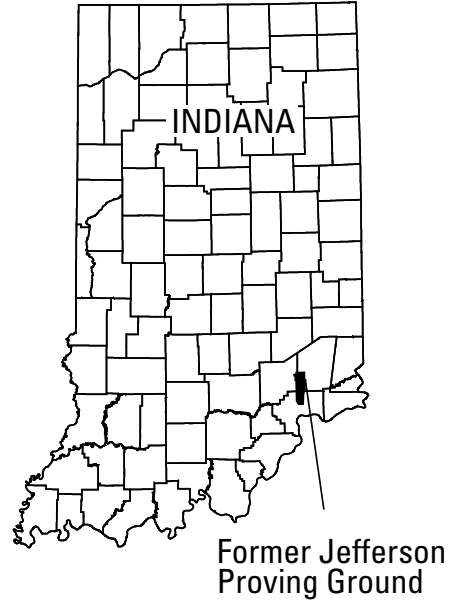

EXPLANATION

Depleted Uranium Impact Area

Area of detailed studyMap extent for figures 10-12, 15, and 17

Former Jefferson Proving Ground boundary

Former firing line

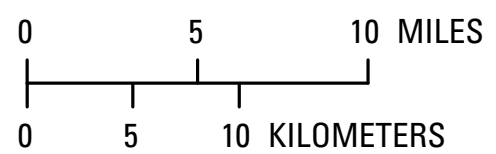

Figure 1. Study area and Depleted Uranium Impact Area, Jefferson Proving Ground, southeastern Indiana.

facility consisted of a northern firing range area (about $80 \mathrm{mi}^{2}$; 51,000 acres) and a southern cantonment area, separated by an east-west oriented firing line. During 1984-94, the Army test fired depleted uranium (DU) projectiles ("penetrators") from three positions along the firing line into an approximately 3.3 $\mathrm{mi}^{2}$ (about 2,100 acres) area north of the firing line, known as the DU Impact Area (fig. 1). Possession and test firing of DU penetrators into the DU Impact Area were done under a license issued by the Nuclear Regulatory Commission (NRC) (License SUB-1435, Docket 040-08838).

The potential contaminant sources examined during this investigation are the possible leaching of DU from remaining penetrators and corrosion products from the penetrators into groundwater in and around the vicinity of the DU Impact Area. The potential transport of DU and its corrosion products in groundwater and surface water and their environmental fate is a matter of concern to the Army, the NRC, and local residents. Natural uranium is composed of three radioactive isotopes of uranium (U); the isotopes are identified by their atomic mass numbers ${ }^{238} \mathrm{U}$ (99.2745 percent by mass), ${ }^{235} \mathrm{U}$ ( 0.7200 percent by mass), and ${ }^{234} \mathrm{U}(0.0055$ percent by mass $)$
(Smith, 2001, p. iii; Grossblatt, 2008). DU is the fraction of uranium that remains after natural uranium is processed to preferentially remove one of its isotopes (uranium-235).

The Army has petitioned the NRC to decommission the DU Impact Area. In 2006, the Army and its contractor, Science Applications International Corporation (SAIC), began investigating the hydrology and hydrogeologic framework of parts of the area north of the firing line to better understand the nature and extent of possible groundwater contaminants from DU-penetrator testing and processes that would affect their fate and transport. The Army and SAIC installed observation wells in 2007 in unconsolidated glacial till overburden (Pre-Wisconsinan till) and in shallow and deeper units within carbonate bedrock ("shallow carbonate unit" and "deep carbonate unit") in and around the DU Impact Area (fig. 2). The Army and SAIC also monitored surface-water stage in the Big Creek and Middle Fork Creek drainage areas and springflow at gaged sites located within and at the upgradient and downgradient boundaries of the DU Impact Area; however, those sites and results are not discussed in this report. The hydrologic data were collected to provide information to further refine the 


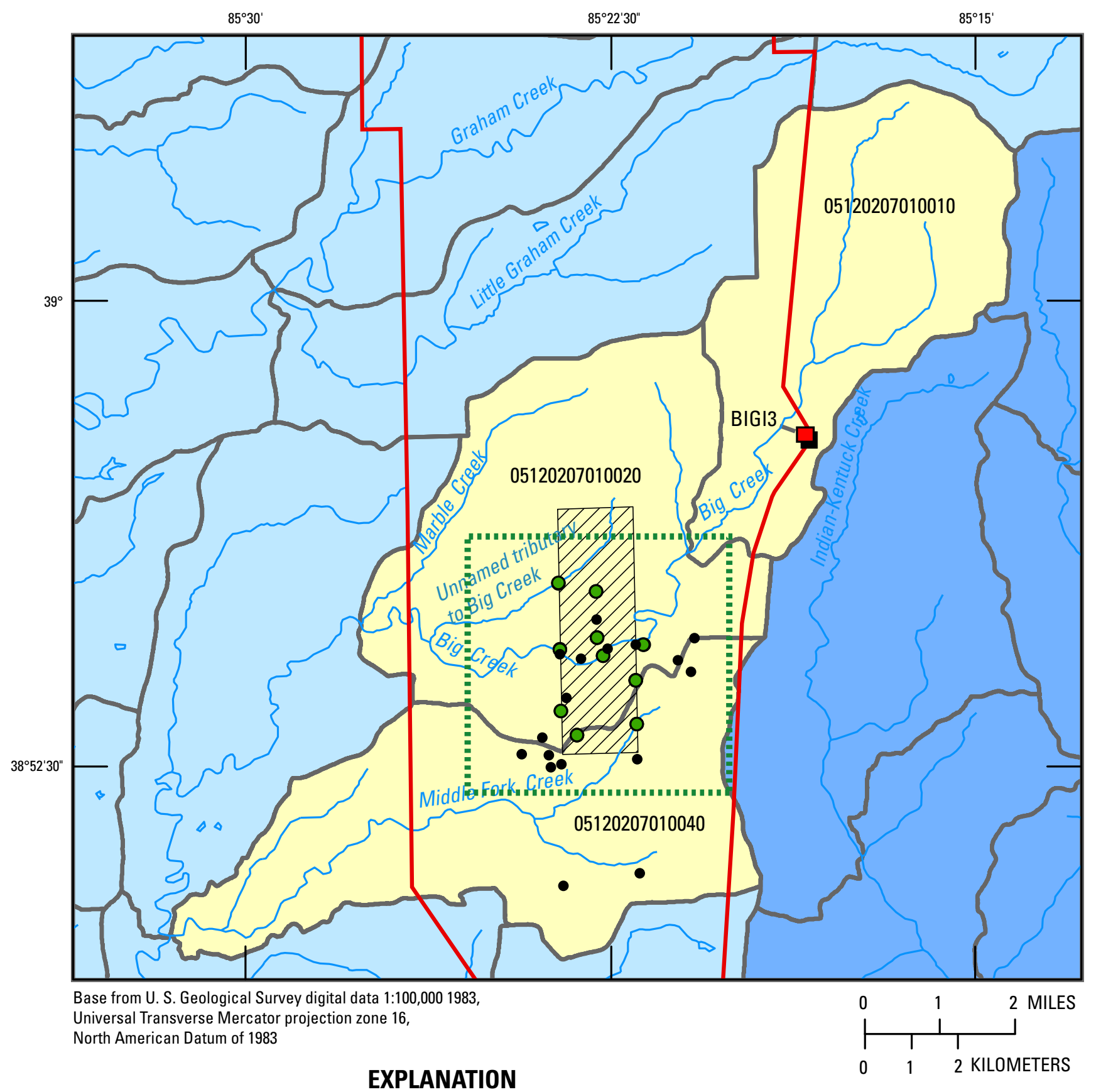

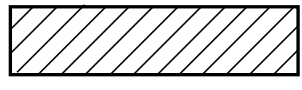

05120207010040
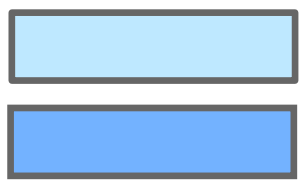

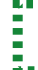

Depleted Uranium Impact Area, approximate

Study watersheds with 14-digit hydrologic unit code (watershed name in report body)

East Fork White River Watershed

Ohio River Watershed

Area of detailed study - Map

extent for figures $10-12,15$, and 17
Former Jefferson Proving Ground boundary

Monitoring wells from depleted uranium study

Monitoring wells from previous studies

${ }^{B I G I 3} \square \quad$ Big Oaks National Wildlife Refuge weather station and identifier

Figure 2. Approximate extent of Depleted Uranium Impact Area relative to watersheds, monitoring wells, and a weather station, Jefferson Proving Ground, southeastern Indiana. 
conceptual site model (CSM) of site hydrogeology and to identify locations that are best suited for sampling groundwater and monitoring groundwater levels in these zones.

Prior studies in other carbonate aquifers have identified how understanding the age of groundwater since it recharged to an aquifer ("age dating"), in combination with conventional hydrogeologic methods, can help define groundwater-flow mechanisms and factors that affect transport of possible contaminants (Lindsay and others, 2003, 2009). Groundwater age is defined as an estimated number of years since infiltrating water reached the water table and recharged the aquifer. Application of multiple age-dating tracers, such as tritium and chlorofluorocarbon compounds, can assist in the verification of dates of groundwater age and identify likely mixtures involving waters of different ages since recharge (Plummer and others, 2003). This knowledge can be used to evaluate whether wells produce water that recharged before or after the introduction of a possible contaminant source or that represent a "mixture" of water with those ages. Estimates of the groundwater age from observation wells also can be helpful in interpreting the groundwater-flow system, groundwater-chemistry data, and geochemical modeling of potential DU-constituent transport.

As part of the overall hydrologic investigation, the U.S. Geological Survey (USGS), in cooperation with the Army and in coordination with SAIC, began an investigation in 2007 to characterize the age of water from wells developed in the Pre-Wisconsinan till, shallow carbonate, and deep carbonate hydrogeologic units in and near the DU Impact Area. Age dates of groundwater can assist with the interpretation of groundwater chemistry and of subsurface processes affecting transport of corrosion products from DU-penetrator testing. Dates of groundwater age can aid in the identification of which wells produce water whose recharge dates from before about 1984 . Wells with age dates predating the penetrator testing can be used to assess background pre-testing water-chemistry conditions. These wells, by definition, sample parts of the hydrogeologic units that were not susceptible to DU contamination when the sampling was done. Wells with age dates after the onset (1984) of DU-penetrator testing and that have a plausible connection to a contaminant source can be used to indicate the presence or absence of contaminants from DU penetrator or DU-related corrosion products in groundwater.

\section{Purpose and Scope}

This report describes the results of an investigation to identify the age of groundwater in Pre-Wisconsin till, shallow, and deeper carbonate bedrock units in and near the DU Impact Area at Jefferson Proving Ground, Indiana, using analyses of tritium, chlorofluorocarbon (CFC) compounds, and dissolved gases. The dates of groundwater age were used to evaluate whether recharge dating from the onset of DU-projectile testing (1984) or later had reached the sampled intervals of the hydrogeologic units and thereby classify the suitability of wells to monitor groundwater quality for effects related to leaching of DU penetrator or DU-related corrosion products. The report also describes basic information about the hydrogeologic framework of water-bearing units sampled in the study area, with special emphasis on differences between groundwater levels in the unconsolidated Pre-Wisconsinan till, and in the shallow and deeper parts of carbonate bedrock formations. The water-level data also were used in the selection of wells for sampling and analysis and to estimate recharge altitudes for CFC-based age-dating analysis. Dissolved-gas analyses of groundwater were interpreted to estimate the temperature of water at the time it infiltrated below the water table and into groundwater; the recharge temperatures are used to estimate the atmospheric mixing ratios of CFCs that are used for age dating.

Groundwater ages that were younger than about 1980 (1984 being the onset of DU-projectile testing) were used to indicate wells that produce water potentially capable of indicating water-quality conditions affected by DU-projectile testing and the subsequent potential leaching of DU and corrosion products into groundwater. Groundwater ages older than about 1980 were used to classify wells that were not immediately susceptible to contamination from DU penetrator or DU-related corrosion products.

\section{Description of the Study Area}

The part of the study area that encompasses the sampled wells, the "area of detailed study," includes about $12.7 \mathrm{mi}^{2}$ of Jefferson Proving Ground in central Jefferson County, southeastern Indiana (fig. 2). The DU Impact Area is within area of detailed study; the DU Impact Area is about $3.3 \mathrm{mi}^{2}$ (fig. 2). The study area includes the watersheds of streams that flow to the west and southwest across the study area including Middle Fork Creek and unnamed tributaries (within 14-digit hydrologic unit 05120207010040—Middle Fork Creek—Jefferson) and Big Creek and unnamed tributaries (within 14-digit hydrologic unit 05120207010020—Big Creek-Marble Creek; fig. 2; DeBroka and Cohen, 1999). The drainage areas of these hydrologic units extend both upstream and downstream from the DU Impact Area; surface water from these areas drains to the Muscatatuck River and then to the East Fork White River. East of the study area, streams flow to the east, then south to the Ohio River.

Land-surface altitudes are highest in the flat upland areas between drainages and range from about 880 to $890 \mathrm{ft}$ above the vertical datum (U.S. Geological Survey, 1959, 1992). Land-surface altitudes are lowest in the valleys of streams that cross the study area, about $770 \mathrm{ft}$ above the vertical datum, about $1.5 \mathrm{mi}$ west and downstream from where Big Creek leaves the DU Impact Area; 810 to $820 \mathrm{ft}$ above the vertical datum in the valley of a tributary to Middle Fork Creek, about $0.75 \mathrm{mi}$ downstream from where it flows out of the DU Impact Area; and about $830 \mathrm{ft}$ above the vertical datum where an 
unnamed tributary of Big Creek flows to the southwest, about 1.5 west of the DU Impact Area (U.S. Geological Survey, 1959, 1992).

The climate of Jefferson Proving Ground area is continental and is characterized by strongly marked seasons (Scheeringa, 2002). The study area is in the transition zone between cool polar air to the north and warm, tropical moisture-laden air masses from the south. Summers are hot and humid; winters are cold and damp. Temperatures range from an average high/low of $3.7 /-5.2^{\circ} \mathrm{C}$ in January to a high/low of $30.3 / 19.1^{\circ} \mathrm{C}$ in July, based on weather data for Madison, Indiana, for 1971-2000 (Midwestern Regional Climate Center, 2009a). The average annual temperature for Madison was $12.6^{\circ} \mathrm{C}$ during 1971-2000 (Midwestern Regional Climate Center, 2009a). Average monthly precipitation for Madison typically ranges from 2.92 in. in September to 4.96 in. in May (Midwestern Regional Climate Center, 2009b). The average annual precipitation for Madison during 1971-2000 was 46.09 in./year (Midwestern Regional Climate Center, 2009b). Precipitation is greatest during March-August but is received each month of the year.

Uses of areas north of the firing line are chiefly forested land, grassed land, and wetlands. Areas north of the firing line contain unexploded ordnance and residue from testing of nonexplosive ordnance and projectiles. The U.S. Fish and Wildlife Service has managed the wildlife resources of JPG since 1996 and for most of JPG north of the firing line (including the DU Impact Area) as an overlay refuge named "Big Oaks National Wildlife Refuge" since June 2000. The U.S. Fish and Wildlife Service manages the refuge under a 25-year agreement in which the Army retains ownership of JPG.

\section{Hydrogeologic Framework}

The hydrogeologic framework is summarized in terms of the water-bearing units that were sampled and their relation to physiography and geology. The study area is in the southeastern part of the Muscatatuck Plateau physiographic division of the Southern Hills and Lowlands region of Indiana (Gray, 2000, plate 1). The area is part of the westernmost extent of the Vernon Segment hydrogeologic terrain (Fleming and others, 1995), a west to southwest sloping set of gently rolling to flat erosional surfaces that have been incised and dissected by streams that are tributary to the Muscatatuck River.

The area is south and outside the limit of Wisconsin glaciation; this report refers to the till and related unconsolidated overburden (soil and loess) in the study area as PreWisconsinan till. Till surfaces generally are flat to gently sloping on upland areas but are deeply dissected and completely removed along the most deeply incised stream channels along Big Creek, Middle Fork Creek, and other tributaries. The till is described as a poor aquifer because of the abundance of clay and silt and the lack of coarse grained aquifer units (Greeman, 1981); these characteristics would also make the Pre-Wisconsinan till a poor medium for contaminant transport.
Recharge to water-bearing units below the fine grained till occurs slowly but is thought to be more rapid where the till is thinnest or removed by erosion.

The Pre-Wisconsinan till is underlain by near-surface carbonate rocks that are part of the lower limestone and dolomite sequence of Silurian Age and the Whitewater Formation of Ordovician Age, as described by Greeman (1981). The bedrock surface is described as dipping westward at about $20 \mathrm{ft} / \mathrm{mi}$ (Schneider, 1966). The lower limestone and dolomite sequence beneath the study area likely includes lower parts of the Salamonie Dolomite and the Brassfield Limestone (Gray, 1972; Shaver and others, 1986). The Salamonie Dolomite is described as argillaceous limestone, dolomitic limestone with shale partings, and ranges in thickness from 0 to about $80 \mathrm{ft}$ in and near JPG (Shaver and others, 1986; Greeman, 1981). The Brassfield Limestone is described as ranging in thickness from 0 to $20 \mathrm{ft}$ and generally as a medium- to coarse-grained fossiliferous limestone with some dolomite. The Whitewater Formation is characterized as thinly interbedded limestone, argillaceous limestone and shale beds, with shale beds increasing with depth.

Sizeable areas of the Vernon segment hydrogeologic terrain in southeastern Indiana include carbonate bedrock that exhibits karst solution features, including sinkholes, solution enlarged joints and fractures, and a few small caves (Fleming and others, 1995). The principal karst development in the carbonate rock in this physiographic division typically is restricted to narrow areas close to the entrenched streams (Gray, 2000, p. 11), although some karst development beneath thin drift deposits is possible. In this area, the upland surface between areas of incised drainage slopes westward at a rate somewhat less than the regional dip of Silurian strata. The easternmost part of the study area borders parts of the western extent of the Newpoint Plain, a largely plateau area east of the study area and JPG.

Fracture-trace analysis (Greeman, 1981; Science Applications International Corporation, 2007a) and surface geophysical surveys (electrical imaging; Science Applications International Corporation, 2007a) indicated evidence of karst features and preferential flow pathways in the subsurface beneath and adjacent to the DU Impact Area. The SAIC electrical-imaging survey also provided data that indicated a paleokarst surface that may have appreciable relief (from about 20 to $100 \mathrm{ft}$ ) beneath the Pre-Wisconsinan till; that surface indicated by resistivity of about $450 \mathrm{ohm}$-meters or more. Caves have been mapped in limestone exposures in JPG along Big Creek (19 caves) and Middle Fork Creek (2 caves), although not all had active flowing groundwater (Sheldon, 1997). The uppermost 20 to $30 \mathrm{ft}$ of the carbonate bedrock at sites south of the firing line contributed water to vertical flowmeter tests of aquifer properties by Wilson and others (2001). Although similar data are not available for wells north of the firing line, many wells installed by SAIC and during prior hydrogeologic investigations were screened or open to permeable zones within about 1 to $40 \mathrm{ft}$ below the till-bedrock interface. 
Based on the above descriptions, the water-bearing units sampled for this study have been divided for the purpose of this investigation into the following preliminary hydrogeologic framework: Pre-Wisconsinan till, shallow carbonate unit, and deep carbonate unit (table 1). Wells classified as producing groundwater from Pre-Wisconsinan till have well screens that are open to overburden deposits above the bedrock surface. Wells classified as producing groundwater from the shallow carbonate unit have well screens that are open to the carbonate bedrock within about 1 to $40 \mathrm{ft}$ below the bedrock surface. The shallow carbonate unit is not a true stratigraphic classification; it represents a zone of fractures, paleokarst, and other dissolution-modified features within the upper $40 \mathrm{ft}$ of carbonate bedrock. The deep carbonate unit is defined by wells that are completed at depths of more than $40 \mathrm{ft}$ below the bedrock surface or are isolated by zones of very low permeability. The deep carbonate unit represents a less transmissive and less productive sequence of the carbonate bedrock and may be characterized by longer groundwater flow paths and older recharge.

\section{Methods of Data Collection and Analysis}

Fifteen observation wells were selected to sample and analyze groundwater for concentrations of several dissolved gases, tritium, and CFCs. These 15 wells were selected from among the 23 wells installed in 2007 by SAIC as part of evaluating the hydrogeologic framework of the DU Impact Area (fig. 3); they are identified with the prefix "JPG-DU." These 23 wells were installed in areas where, according to background data collection, active, watersaturated zones in the hydrogeologic units were most likely to be encountered by drilling. Additional samples were collected from 14 wells installed for prior studies at JPG but that were open to the same hydrogeologic units sampled in the DU Impact Area; those wells are identified with the prefixes "MW" and "MW-RS." The 14 wells are within the DU Impact Area and in adjacent areas of JPG; water sampled from those wells was analyzed for concentrations of tritium only. Geologic and well-construction information about these well locations is summarized in table 2 (at end of report). The JPG-DU wells were accessible by previously cleared roads and are at sites that have been examined for DU and unexploded ordnance. The MW and MW-RS wells were in areas with more limited examination and access; those samples were collected for USGS by SAIC personnel.

Several criteria were used to indicate the suitability of wells to sample for dissolved gases and age-dating constituents:.

Slow water-level recovery. If water levels in a well did not recover since post-installation pumping and development or did not recover after pre-sampling measurement of field properties and collection of water samples by SAIC, no dissolved gas or age-dating samples were collected.

Some water-level recovery. If water levels in a well recovered since post-installation pumping and development, collection of dissolved gas and age-dating sampling was attempted. This criterion assumes that water-level recovery indicates that the well produced groundwater from a saturated part of a hydrogeologic unit.

Variable water-levels. Sampling of water representative of the aquifer and young-age dates were considered possible if groundwater levels varied by more than $1 \mathrm{ft}$ in periodic measurements. This criterion assumes that the fluctuation was a function of infiltration of recharge to the aquifer and an possible expression of younger age groundwater in the well or interconnection with relatively younger flow paths in the hydrogeologic units. Dissolved gas and age-dating samples were collected from those wells.

Based on the above criteria, water from 5 JPG-DU series wells from the Pre-Wisconsinan till unit were sampled for dissolved gases, tritium, and CFCs and water from 8 wells from prior studies in that unit were sampled for tritium only (fig. 3; table 3). Water from 8 JPG-DU series wells in the shallow carbonate unit were sampled for dissolved gases, tritium, and CFCs and water from 6 wells from prior studies in that unit were sampled for tritium only (fig. 3; table 3). Two wells in the shallow carbonate unit could not be sampled because of poor water level recovery and three wells from prior studies were not sampled because they had been visited and sampled prior to the USGS sampling in April 2008. Only two wells from the deep carbonate unit were sampled for dissolved gases, tritium, and CFCs; seven other wells in the deep carbonate unit could not be sampled because of poor water level recovery (fig. 3; table 3).

\section{Sampling and Analyses of Groundwater Chemistry}

Water samples for age-dating analysis were collected at wells sampled by SAIC in April 2008. Observation wells sampled for this investigation were developed by SAIC about 1 month or more before sampling, using procedures described in Field Sampling Plan Addendum 4 (Science Applications International Corporation, 2007b). Samples from monitoring wells were collected with a portable, positive displacement, low-capacity gear-driven submersible pump (Fultz Pumps, Inc.). The pump used Teflon rotors in a stainless steel pump cavity and housing to push water through a stainless steel discharge adaptor fitting that split flow to two tubes. The pump was lowered nearly to the bottom of each sampled well, then raised about $3 \mathrm{ft}$ for operation during measurements of field properties and sample collection. Groundwater flow from the adaptor fitting was routed to land surface through one of two tubes: (1) a 0.5 in. outside diameter tube used by SAIC for measurement of field water-quality parameters and (2) a 0.18 in. inside diameter nylon tube that was used for 


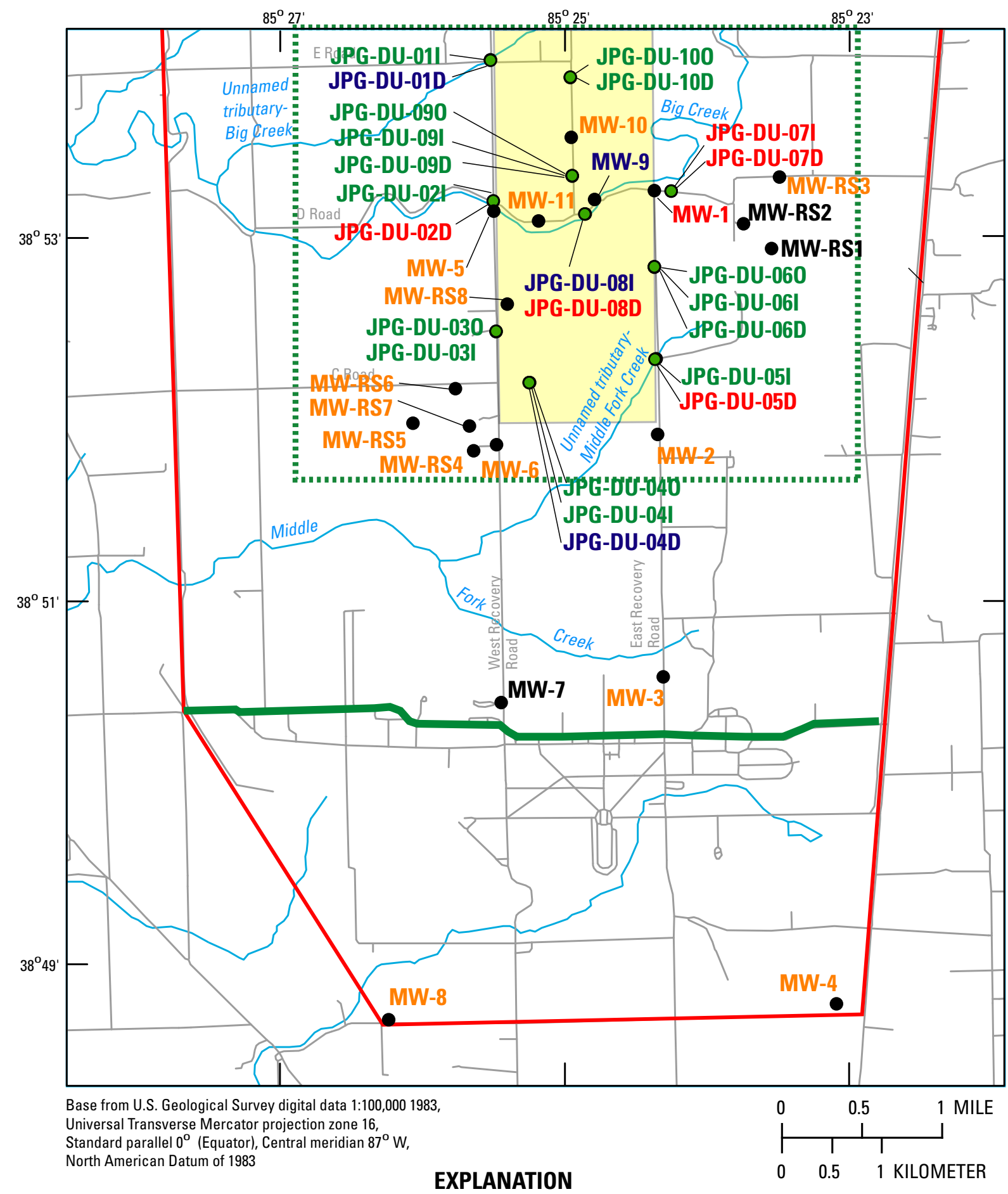

\begin{tabular}{|c|c|}
\hline & $\begin{array}{l}\text { Depleted Uranium Impact Area, } \\
\text { approximate }\end{array}$ \\
\hline & $\begin{array}{l}\text { Area of detailed study-Map } \\
\text { extent for figures } 10-12,15 \text {, and } 17\end{array}$ \\
\hline & $\begin{array}{l}\text { Approximate boundary, former } \\
\text { Jefferson Proving Ground }\end{array}$ \\
\hline & Former location of firing line \\
\hline 0 & Wells installed for this study \\
\hline$\bullet$ & Wells from previous studies \\
\hline
\end{tabular}
JPG-DU-30 Wells sampled for CFC and tritium in green type MW-4 Wells sampled for tritium in orange type
JPG-DU-05D Wells not sampled -- DRY in red type
JPG-DU-04D Wells not sampled -- INSUFFICIENT WATER TO SAMPLE -- in blue type

MW-7 Wells not sampled -- sampled previously by SAIC in black type

Figure 3. Monitoring wells in the study area, Jefferson Proving Ground, southeastern Indiana. 
Table 1. Generalized hydrogeologic framework of water-bearing units sampled for this study, Jefferson Proving Ground, southeastern Indiana.

[ft, feet; NAVD 88, North American Vertical Datum of 1988]

\begin{tabular}{|c|c|c|c|}
\hline \multirow[b]{2}{*}{ Lithostratigraphic descriptions } & \multicolumn{3}{|c|}{ Hydrogeologic framework characteristics } \\
\hline & $\begin{array}{l}\text { Unit name } \\
\text { in this report }\end{array}$ & Characteristic & $\begin{array}{l}\text { Range of depths for bottom } \\
\text { of well screen below land } \\
\text { or bedrock surface } \\
\text { (ft below NAVD 88) }\end{array}$ \\
\hline $\begin{array}{l}\text { Pre-Wisconsinan till, commonly } \\
\text { weathered, with silts, silty } \\
\text { clay, with infrequent sand and } \\
\text { gravel bodies. May also include } \\
\text { a veneer of late-Wisconsinan } \\
\text { loess and silty colluvium }\end{array}$ & $\begin{array}{l}\text { Pre-Wisconsinan } \\
\quad \text { till }\end{array}$ & $\begin{array}{l}\text { Confining unit for shallow carbonate unit, } \\
\text { groundwater flow considered principally to } \\
\text { be vertical and slow relative to the shallow } \\
\text { carbonate unit. Some horizontal groundwater } \\
\text { flow can be expected along small sand and } \\
\text { gravel lenses and weathered zones. }\end{array}$ & $\begin{array}{l}\text { Depth of top of well screen below } \\
\text { land surface for sampled wells: } \\
\text { about } 5 \mathrm{ft} \text { to about } 58 \mathrm{ft} \\
\text { Depth of bottom of well screens: } \\
\text { about } 12 \mathrm{ft} \text { to about } 68 \mathrm{ft}\end{array}$ \\
\hline $\begin{array}{l}\text { Carbonate bedrock, substantially } \\
\text { of rocks of Silurian and } \\
\text { Ordovician age }\end{array}$ & $\begin{array}{l}\text { Shallow } \\
\text { carbonate unit }\end{array}$ & $\begin{array}{l}\text { Parts of carbonate aquifer, where fractured or } \\
\text { dissolution modified. }\end{array}$ & $\begin{array}{l}\text { Depth of bottom of well screen } \\
\text { below bedrock surface for } \\
\text { sampled wells: about } 9 \mathrm{ft} \text { to } \\
\text { about } 40 \mathrm{ft}\end{array}$ \\
\hline
\end{tabular}

dissolved gases, tritium, and CFC sampling. Flow from the larger diameter tubing was routed to a flow cell connected to a multiparameter instrument (Horiba model U-22), which was used to collect field measurements of water-quality parameters. Water-quality parameters were measured until they stabilized to \pm 0.1 standard units for $\mathrm{pH}, \pm 25 \mu \mathrm{S} / \mathrm{cm}$ for specific conductance, $\pm 0.2 \mathrm{mg} / \mathrm{L}$ for dissolved oxygen, and $<50$ Nephelometric Turbidity Units (NTU) for turbidity. The convention NTU is used in this report to report turbidity data to be consistent with the procedures used to measure waterquality parameters; those are described in Field Sampling Plan Addendum 5 (Science Applications International Corporation, 2008).

After water samples were collected by SAIC for analysis of other constituents, groundwater discharge was routed through the $0.18 \mathrm{in}$. inside diameter nylon tube to collect the dissolved gases, tritium, and CFC samples. The pump was operated at variable flow rates, $0.5 \mathrm{~L} / \mathrm{min}$ or less, during this sampling.
Unfiltered samples of groundwater for tritium analysis were collected directly from the discharge end of the nylon tubing into pre-cleaned, 1-L polyethylene bottles, sealed with a polyseal cap, with the cap taped in place using a strip of standard electrical tape. Samples were shipped in sealed coolers to the USGS Isotope Tracers Project Laboratory, Menlo Park, Calif. The samples were analyzed for concentration of tritium by counting the rate of tritium decay by beta (electron) emissions from neutron decay to stable helium using a standard electrolytic enrichment, liquid scintillation method (Thatcher and others, 1977) with a detection limit of 0.1 tritium units (TU) (table 4). For comparison to other work, 3.2 picocuries of tritium per liter is equal to $1 \mathrm{TU}$. A TU equals 1 tritium atom for every 1018 atoms of hydrogen. For $1 \mathrm{~L}$ of water, $1 \mathrm{TU}$ is equivalent to 0.12 tritium atom disintegrations per second (Lucas and Unterweger, 2000).

Unfiltered samples of water were collected in the field in pre-weighed $150-\mathrm{mL}$ serum bottles that were filled without headspace for analyses of dissolved gas, including oxygen,

Table 3. Number of wells sampled and not sampled for this study from each hydrogeologic unit.

[USGS, U.S. Geological Survey; SAIC, Science Applications International Corporation]

\begin{tabular}{|c|c|c|c|c|}
\hline $\begin{array}{l}\text { Hydrogeologic unit } \\
\text { name }\end{array}$ & \multicolumn{2}{|c|}{ Number of wells sampled, by type of analysis } & \multicolumn{2}{|c|}{ Number of wells not sampled, with reason } \\
\hline Pre-Wisconsinan till & 5 & 8 & 0 & 0 \\
\hline Shallow carbonate & 8 & 6 & 2 & 3 \\
\hline
\end{tabular}


Table 4. Analytical methods used for groundwater samples collected for analyses of dissolved gases and age dating at the Jefferson Proving Ground, southeastern Indiana.

[--, not available or not known; USGS, U.S. Geological Survey; GC-MS, gas chromatography-mass spectometry; ]

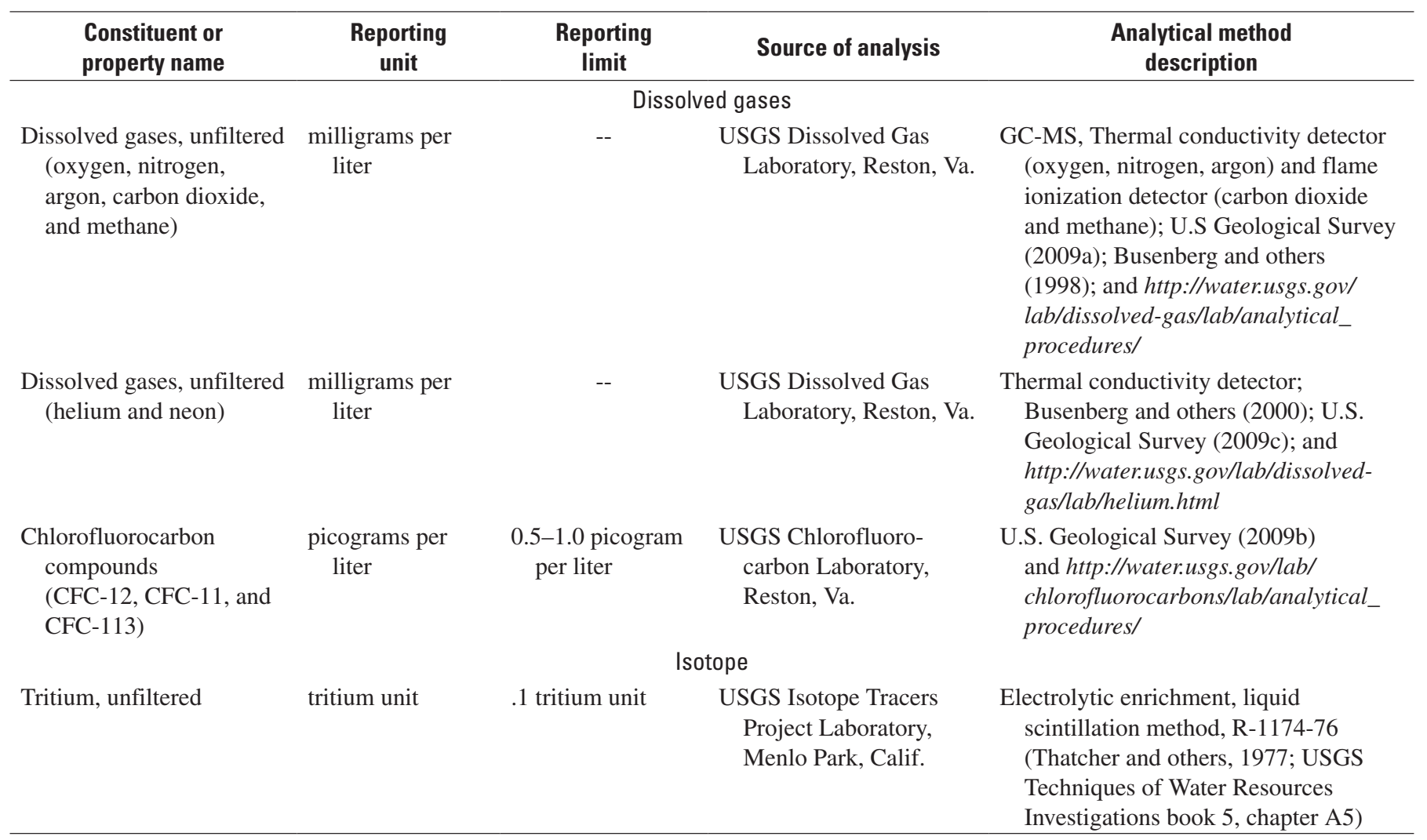

nitrogen, argon, carbon dioxide, methane, helium, and neon; then stored on ice after collection, and in a refrigerator at $4^{\circ} \mathrm{C}$ in the laboratory before their analysis. Water samples were collected and analyzed for dissolved gases using methods in U.S. Geological Survey (2009a) and Busenberg and others $(1998,2000)$ (table 4). Sequential replicate samples were collected and analyzed for oxygen, nitrogen, argon, carbon dioxide, and methane but not for helium and neon. Samples were shipped on ice to the USGS Dissolved Gas Laboratory in Reston, Virginia, for analysis.

The analyses of argon and nitrogen are checked at the lab by analyzing standard samples prepared at known temperatures in equilibrium with air and using those results to compute the air-water equilibrium temperature. The concentrations of argon and nitrogen for these analyses yielded computed air-water equilibrium temperatures within $0.5^{\circ} \mathrm{C}$ of their preparation temperature in all 12 of the standard samples analyzed (Peggy Widman, U.S. Geological Survey, written commun., 2009). The precision of the analytical results for helium and neon are 5 to 10 and 10 to 20 percent, respectively.

Unfiltered samples of water were collected to analyze the concentrations of chlorofluorocarbon compounds (CFCs), dichlorodifluoromethane (CFC-12 or $\mathrm{CF}_{2} \mathrm{Cl}_{2}$ ), trichlorofluoromethane (CFC-11 or $\mathrm{CFCl}_{3}$ ), and trichlorotrifluoroethane
(CFC-113 or $\mathrm{C}_{2} \mathrm{~F}_{3} \mathrm{Cl}_{3}$ ) in water and compute estimates of groundwater ages. Water for analysis of CFC was collected in $125-\mathrm{mL}$ ( $4 \mathrm{oz}$ ) clear-glass bottles ("sample vials") with aluminum-foil lined bottle caps; five sample vials of groundwater were collected using methods in U.S. Geological Survey (2009b). Water samples were analyzed for concentrations of CFCs by the USGS Chlorofluorocarbon Laboratory in Reston, Virginia, with a purge-and-trap extraction, followed by compound separation with a gas chromatograph, and compound detection with an electron-capture detector (Busenberg and Plummer, 1992) (table 4). Two or three sample vials from each well were selected by laboratory personnel and analyzed for concentrations of CFCs, with a detection limit of about 1 picogram per liter $(\mathrm{pg} / \mathrm{L})$ of water.

\section{Quality-Assurance Sampling and Analyses}

Field quality assurance (QA) components included collection of QA samples and data to evaluate the reproducibility of the sampling and analysis methods for selected dissolved gases and chlorofluorocarbon compounds (sequential replicate samples). Replicate samples were collected sequentially for analysis of CFC and selected dissolved gases and used to evaluate the overall variability of the sampling and analysis procedures. A sequential replicate is a sample collected 
in immediate succession to the water sample from the same source, using the same equipment and methods, and submitted to the same laboratories as the water sample for identical analyses. The variability between analyses from a water sample and a sequential replicate was evaluated by calculating the relative percent difference (RPD) of concentrations of each analyte that was detected in both the water sample and sequential replicate (Olsen and Spencer, 2000; U.S. Army Corps of Engineers, 2008).

$$
\mathrm{RPD}=|(\mathrm{SR}-\mathrm{WS}) /((\mathrm{SR}+\mathrm{WS}) / 2)| \times 100
$$

where

$\mathrm{RPD}$ is the relative percent difference,

$\mathrm{SR}$ is the concentration in the sequential replicate, and

WS is the concentration in the water sample.

The RPD describes the difference in concentrations between two samples that were identical in their handling and analysis and that should be identical in composition. If the RPD of an analysis was within 25 percent, the sample result met the precision objectives of this study. If the RPD was greater than 25 percent, the sample result was reported, but the concentration for that analysis was flagged with the letter "Q" in data tables to indicate that the concentration is an estimate. The RPD precision objective used in this study exceeds the variability typically allowed for environmental analyses (50 percent; U.S. Army Corps of Engineers, 2008).

\section{Estimates of Groundwater Age Using Tritium}

Estimates of groundwater age were made by comparing the activity of tritium in water to its decay-adjusted activity in precipitation samples from the Ohio River Basin, expressed as a range of groundwater age or the age of recharge to groundwater. Tritium is a radioactive isotope of hydrogen; each tritium atom has a mass of 3 atomic mass units and a half-life of 12.33 years (Lucas and Unterweger, 2000). Tritium is produced naturally by the bombardment of nitrogen in the atmosphere by cosmic radiation (Grosse and others, 1951) and is added to the atmosphere by the solar wind. Atmospheric tritium and oxygen then combine to form water, which enters the groundwater system through infiltration of precipitation. Although few measurements are available, the natural concentration of tritium in precipitation before 1953 was estimated to be about 6 to 8 TU (Thatcher, 1962) and the estimated concentration of tritium in Ohio River Basin precipitation before 1952 was about 6-8 TU (Michel, 2004). As a consequence of radioactive decay, a tritium concentration of $8 \mathrm{TU}$ in a water sample collected in 1952 would decrease to about 0.3 TU by April 2008, the sampling date for this study.

Concentrations of tritium were used to classify groundwater-age dates to distinguish between aquifer recharge from precipitation that was 1953 or older (submodern), recharge from precipitation that was younger than 1953 (modern), and mixtures of the two. Concentrations of tritium in precipitation greatly increased from about 1954 through 1980 because of the release of bomb-related tritium from testing of atmospheric thermonuclear devices, the greatest release happening from 1953 through 1962 (fig. 4; Clark and Fritz, 1997; International Atomic Energy Agency, 2006). For example, concentrations of tritium in Ottawa, Canada precipitation, a station with a long data record, were quite variable between samples but increased from about 20 TU in August 1953 to about 5,800 TU in June 1963. By about 1990, bomb-related tritium largely had been removed from the atmosphere and concentrations of tritium in precipitation had returned to near natural levels (fig. 4).

Tritium in precipitation varies with latitude; therefore, monthly estimates of concentrations of tritium in Ohio River Basin precipitation were used for age-dating estimates (fig. 4; Robert Michel, U.S. Geological Survey, written commun., 2009; Michel, 2004). Estimated concentrations of tritium for the Ohio River Basin were based on, but generally less than, the Ottawa, Canada data; they increased from about 15 TU in August 1953 to about 2,600 TU in May 1963 and then gradually decreased to about 7 TU by December 2001 (Robert Michel, U.S. Geological Survey, written commun., 2009; Michel, 2004; International Atomic Energy Agency, 2006).

Concentrations of tritium for the Ohio River Basin were estimated by averaging concentrations of tritium in precipitation from sites at Chicago, Illinois, and St. Louis, Missouri, as indicated in Michel (2004). Although the uncertainty of estimates of concentrations of tritium in Ohio River Basin precipitation have not been evaluated, the correlation coefficients of annual average concentrations of tritium in Ottawa, Canada precipitation, after weighting the data to account for differences in precipitation amounts, were 0.99 with concentrations of tritium from Chicago and 0.93 with concentrations of tritium from St. Louis (International Atomic Energy Agency, 1981).

Groundwater-age dates were evaluated for concentrations of tritium in groundwater by comparing them with annual averages of concentrations of tritium in precipitation, corrected for decay to the date of sample collection. When tritium in precipitation falls and infiltrates into groundwater, it continues to undergo decay during its residence time in groundwater until it is sampled. To create a record of concentrations of tritium in precipitation that were comparable to the already decayed concentrations in groundwater, the concentrations of tritium in Ohio River Basin precipitation were annually averaged and decay corrected to the date of sampling (April 2008) using a standard decay equation (Clark and Fritz, 1997, p. 181) and half-life of tritium (12.33 years; Lucas and Unterweger, 2000). Decay corrected, annual average concentrations of tritium estimated for Ohio River Basin precipitation increased from $0.8 \mathrm{TU}$ in 1953 to about 119 TU in 1963, but then decreased to about 8.5 TU by 1972 and to about 4 to 5 TU since 1986 (fig. 5).

The following ranges of concentrations of tritium were used to qualitatively classify groundwater-age dates. These 


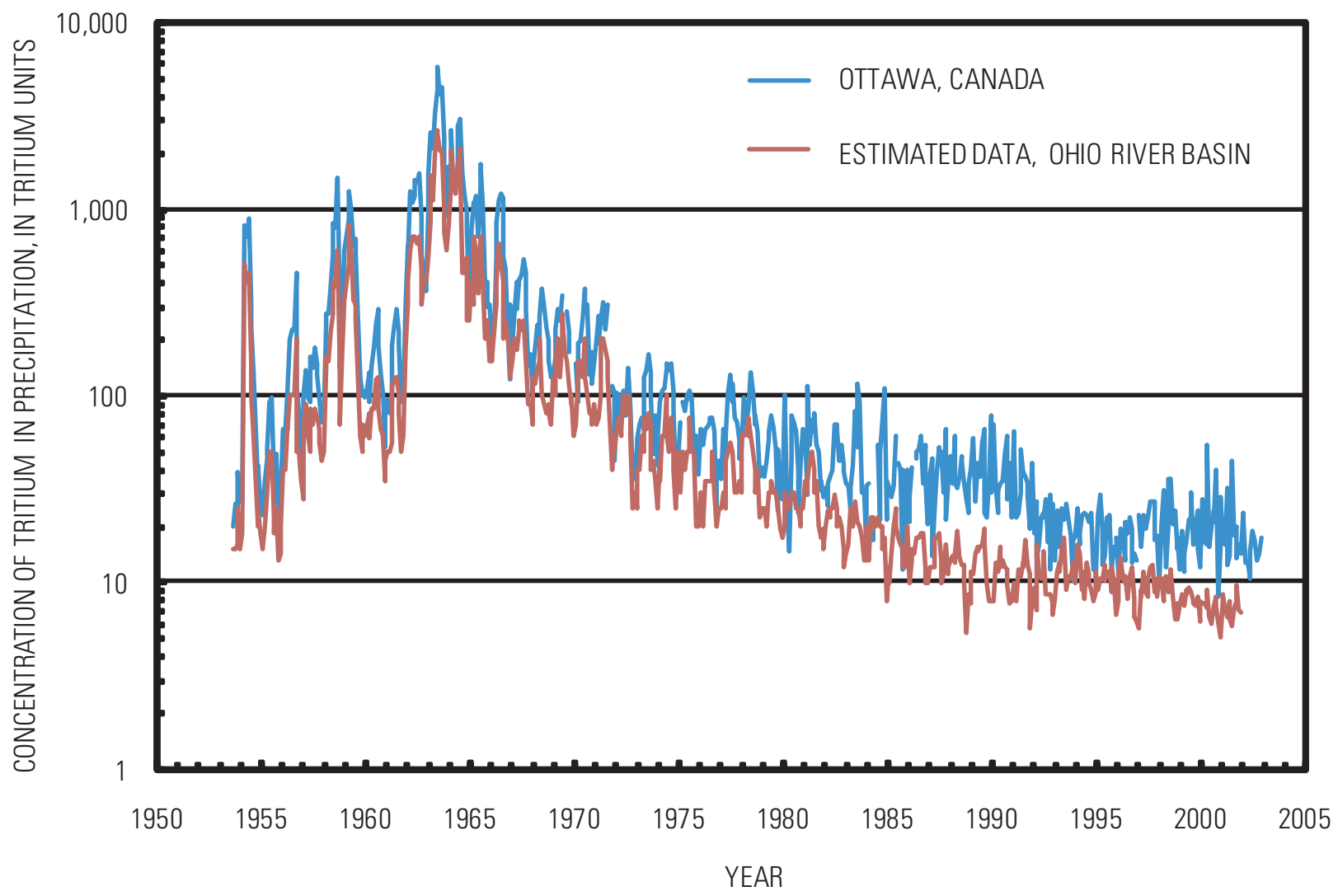

Figure 4. Average monthly concentration of tritium in precipitation in samples collected from 0ttawa, Canada, 1953-2002 (International Atomic Energy Agency, 2006) and monthly estimates of concentrations of tritium in precipitation for the Ohio River Basin (Robert Michel, U.S. Geological Survey, written commun., 2009; Michel, 2004).

classifications were modified from Clark and Fritz (1997, p. 185) and adapted to the record of decay-corrected concentrations of tritium in Ohio River Basin precipitation.

1. Submodern: Less than or equal to about $0.8 \mathrm{TU}-$ Groundwater substantially recharged before or during 1953.

2. Submodern-modern mix: About 0.9 to less than $4 \mathrm{TU}-$ Groundwater is a mixture of pre-recharge from before or during 1953 with recent, post-1953 recharge. The mixture classification explains cases when groundwater represents a mixture of submodern water from slower subsurface flow paths and modern groundwater from faster subsurface flow paths to a well.

3. Substantially modern: About 4 TU to about 15 TUWater represents substantially modern recharge (post1953). In addition, water in this range with about 4 to 8 TU may be a mixture of post-1972 recharge. Smaller concentrations of tritium in this range can also indicate mixing of modern recharge with submodern groundwater.

The analytical precision of concentrations of tritium was added to the tritium concentration of a sample to evaluate the uncertainty of tritium-based estimates of groundwater age. Concentrations of tritium have an associated decay-counting uncertainty referred to as "Tritium, 2-sigma precision." Radioactive decay of tritium is a random process; to account for the randomness while obtaining a precise result, counting is done until a precise number of counts are obtained (Thatcher and others, 1977, p. 69-71). The counting uncertainty (standard deviation or sigma) includes uncertainties in decay counts and other analytical factors and is computed using methods described in Thatcher and others (1977, p. 70 and 71, equations 1-5). The 2-sigma precision indicates that the concentration of tritium reported for a sample has a 95-percent probability of being within plus or minus one standard deviation of the reported concentration. Age classifications that changed when the 2-sigma precision statistic values were added to tritium concentrations were compared with the CFCbased age date to verify the final groundwater-age classification for those samples.

\section{Estimates of Groundwater Age Using Chlorofluorocarbon Compounds}

Concentrations of the three CFC compounds-CFC-12, CFC-11, and CFC-113 - were used to estimate groundwater age for samples collected in and near the DU Impact Area 


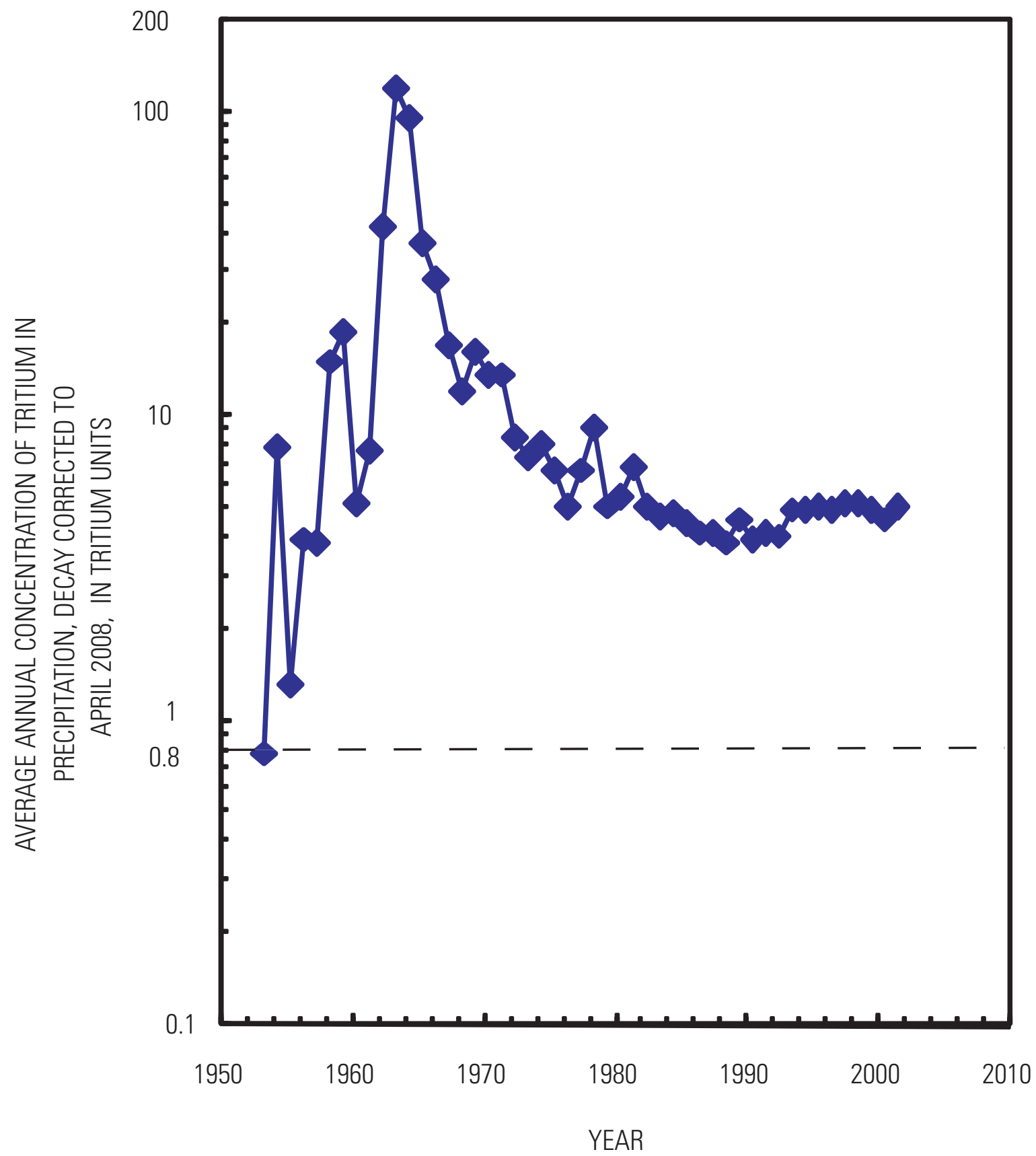

Figure 5. Average annual concentration of tritium in precipitation for the Ohio River Basin, 1953-2001, as corrected for decay to April 2008 when groundwater was sampled. Concentrations were computed using monthly estimates of concentrations of tritium in precipitation for the Ohio River Basin from Robert Michel (U.S. Geological Survey, written commun., 2009; Michel, 2004).

from the Pre-Wisconsinan till, shallow carbonate unit, and deep carbonate units. Estimates of groundwater age are apparent ages and are based on interpretations of measured concentrations of CFCs in groundwater and processes affecting the CFCs from entry into the aquifer with recharge until they are sampled. The following description of CFC-based groundwater-age dating methods and their interpretation are paraphrased from International Atomic Energy Agency (2006) and Rowe and others (1999).
CFC-12, CFC-11, and CFC-113 are stable, synthetic, halogenated alkanes that were developed as refrigerants. Production of CFC-12 began in 1931, followed by CFC-11 in 1936, and CFC-113 in about 1943. Precipitation that dates from about 1940 is assumed to contain one or more of these $\mathrm{CFCs}$; therefore, precipitation that infiltrated into groundwater at JPG after about 1940 is assumed to have contained one or more of these CFCs. Water that contains no CFCs is presumed to represent pre-1940 recharge. The concentrations of the 
CFCs in the atmosphere of North America and in recharge have changed through time (fig. 6); these changes can be used to indirectly estimate groundwater age.

To compute the age of a groundwater sample, concentrations of each CFC compound are divided by the appropriate Henry's Law constant. This result gives the partial pressure of the compound in air from the unsaturated or "vadose" zone above the water table when water infiltrated below the water table and became isolated from the atmosphere. The solubility $\left(C_{D}\right)$ of a $C F C$ compound $(D)$ relates to the equilibrium between gas and water phases, as described by Henry's Law:

$$
C_{\mathrm{D}}=K_{\mathrm{D}(\mathrm{T}, \mathrm{S})} \times P_{\mathrm{D}},
$$

where

$K_{\mathrm{D}(\mathrm{T}, \mathrm{S})}$ is the Henry's law constant for the CFC compound

(D) at a defined average recharge temperature $(T)$ and salinity $(S)$ and

$P_{\mathrm{D}}$ is the partial pressure, under atmospheric conditions

(Schwarzenbach and others, 1993), of the CFC compound (D).
The solubility of dissolved gases (such as CFCs, argon, and nitrogen) depends on the average recharge temperature of the groundwater sample. Recharge temperatures were estimated with the ratio of dissolved nitrogen to argon gas in water samples (Rowe and others, 1999). The concentrations of nitrogen and argon in water infiltrating below the water table may be expected to be in equilibrium with the atmosphere at the prevailing surface pressure and temperature (Heaton and Vogel, 1981). Concentrations of nitrogen and argon were normalized using an assumed recharge altitude to a pressure of $760 \mathrm{~mm}$ of mercury to limit altitude effects on comparison of gas solubility. The recharge altitude is the altitude at which water infiltrates below the water table and becomes isolated from equilibrium with the atmosphere. Recharge altitudes used for recharge temperature and CFC-based groundwaterage computations generally were assumed to be similar to measured water levels at a well or to inferred water levels upgradient from a well to represent recharge from upgradient sources.

Concentrations of nitrogen and argon in groundwater also were corrected for the "excess air" introduced into

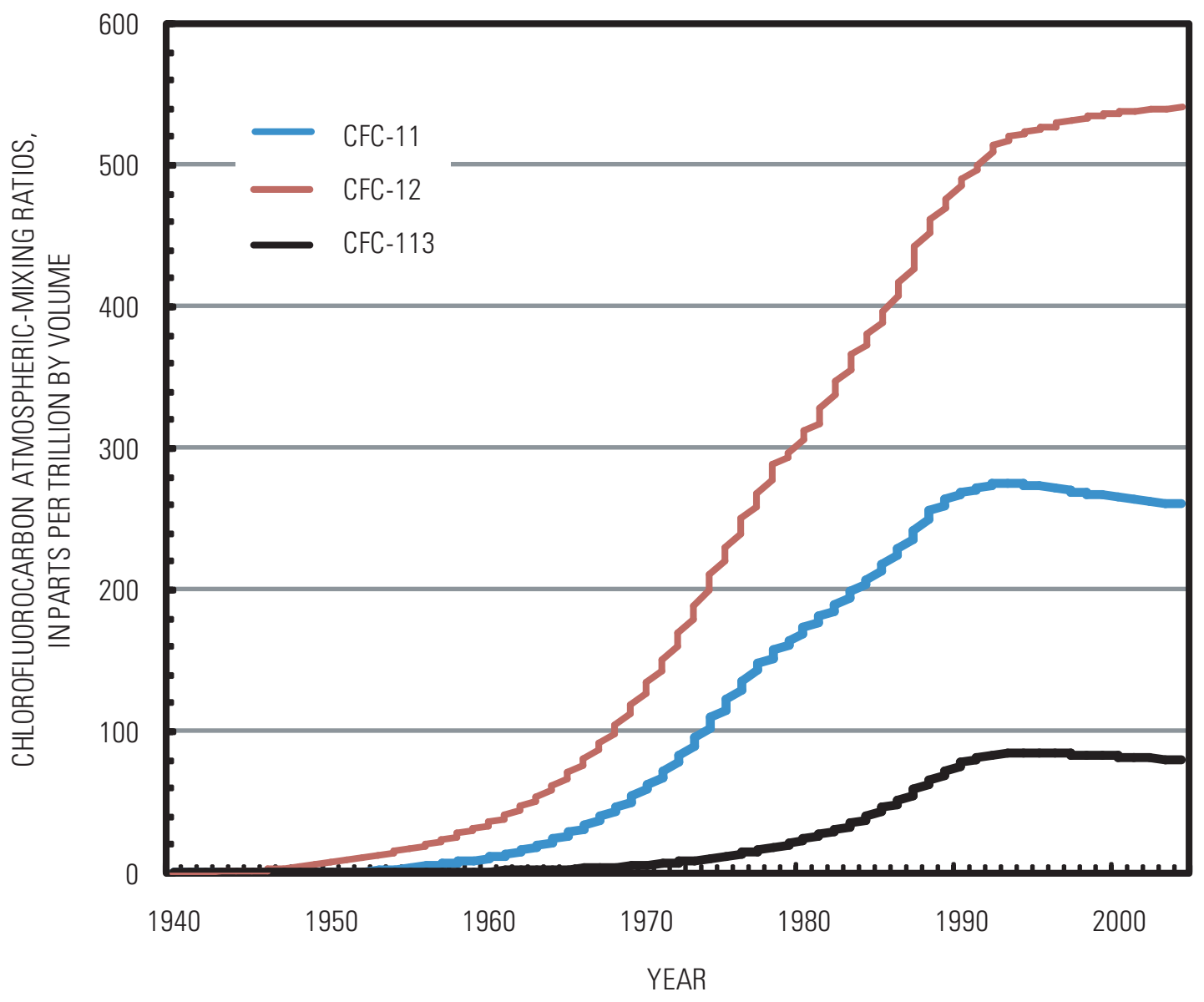

Figure 6. Atmospheric-mixing ratios of dichlorodifluoromethane (CFC-12), trichlorofluoromethane (CFC-11), and trichlorotrifluoromethane (CFC-113) for air in North America (Eurybiades Busenberg and L.N. Plummer, U.S. Geological Survey, written commun., 2006). Data before 1976 were reconstructed from chlorofluorocarbon production data, as referenced and described in Plummer and Busenberg (2000). 
groundwater during infiltration. Infiltrating water can entrap air bubbles that when carried below the water table, dissolve and are incorporated into dissolved gases (Heaton and Vogel, 1981). Excess air refers to the volume of dissolved gas in a liter of groundwater in excess of that predicted by equilibrium of infiltrating water with the atmosphere. Excess air is trapped and dissolved under increased hydrostatic pressure in groundwater at the capillary fringe or in fractures as the water table rises. Introduction of excess air adds CFCs to groundwater and, if not accounted for in age interpretation, causes a young-age bias. Recharge temperatures were estimated as shown on figure 7 for a hypothetical data point by comparing the corrected concentrations of nitrogen and argon gas with a plot of nitrogen-argon solubility in water at $760 \mathrm{~mm}$ of

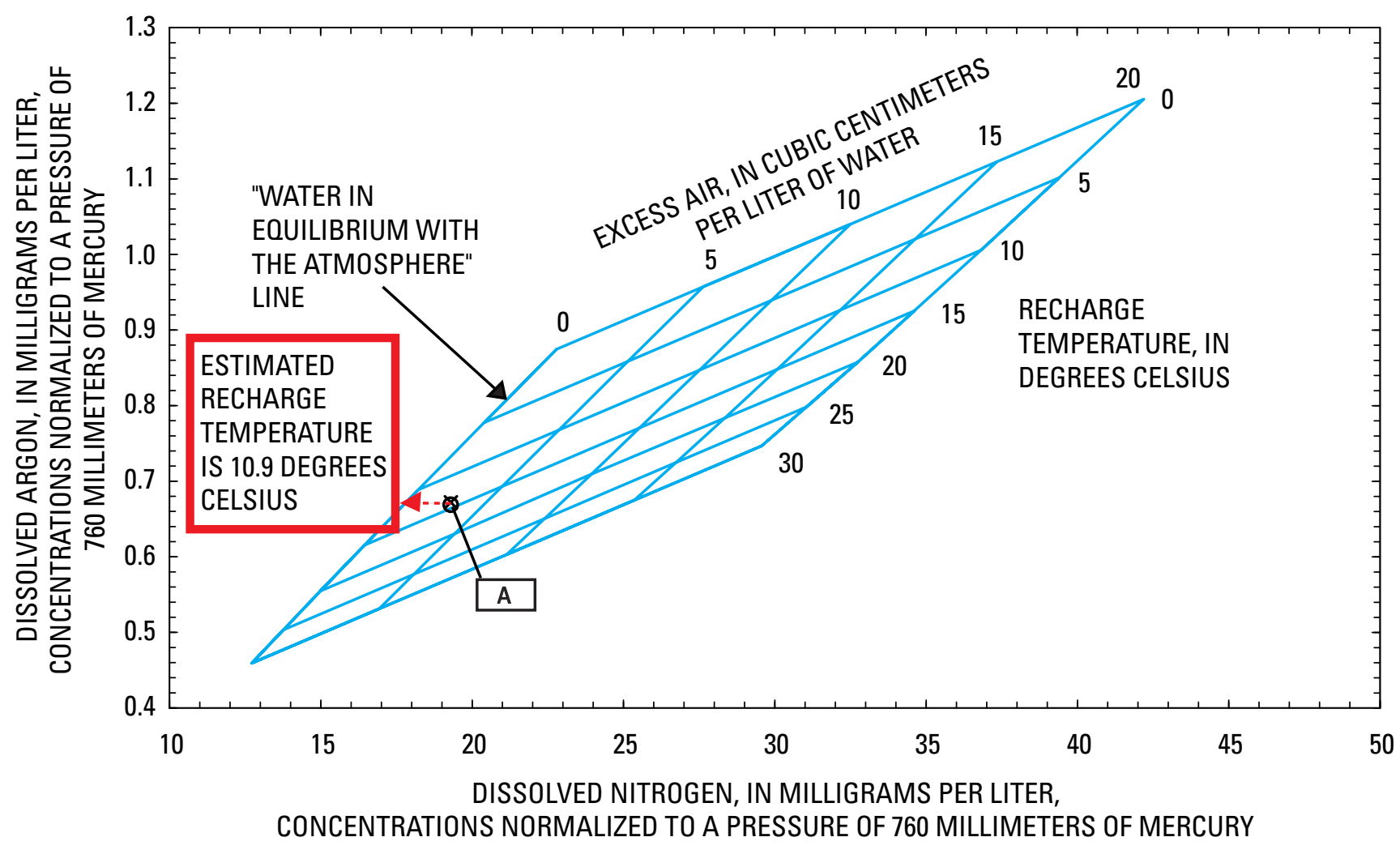

\section{EXPLANATION}

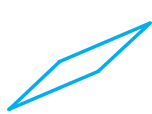

GRIDDED DATA OF HYPOTHETICAL CONCENTRATIONS OF DISSOLVED NITROGEN AND DISSOLVED ARGON IN EQUILIBRIUM WITH VARIOUS RECHARGE TEMPERATURES AND CONCENTRATIONS OF EXCESS AIR

$\times \quad$ HYPOTHETICAL WATER SAMPLE

○ HYPOTHETICAL SEQUENTIAL DUPLICATE

A WELL NAME

Gridded data from Julian Wayland (U.S. Geological Survey, written commun., 2003), as computed using methods from Weiss, R.F., 1970, The solubility of nitrogen, oxygen, and argon in water and seawater: Deep Sea Research, v. 17, no. 4, p. 721-735.

Figure 7. Recharge temperature grid with hypothetical concentrations of dissolved nitrogen and dissolved argon at various recharge temperatures and concentrations of excess air in water samples. 
mercury with excess air contents ranging from 0 to $20 \mathrm{~cm}^{3} / \mathrm{kg}$ of water (Heaton and Vogel, 1981) using gas-solubility data from Weiss (1970).

"Excess nitrogen," if present in a sample, was subtracted from concentrations of nitrogen gas during the computation of corrected concentrations of nitrogen gas that were used in estimation of recharge temperature. Excess nitrogen can originate from biogeochemical processes in an aquifer, such as denitrification, that produce more nitrogen gas than would be dissolved in water in equilibrium with soil gas during recharge; it cannot exceed the total amount of excess air in a sample. Excess nitrogen was estimated by comparing the nitrogen gas in the sample with the amount that should be present if the water sample were in equilibrium with atmospheric nitrogen at the estimated recharge temperature. Excess nitrogen in a water sample can create unrealistically high estimates of recharge temperatures and introduce errors in the CFC-based estimate of groundwater age.

The calculated partial pressures of CFCs in each water sample, corrected for the amount of excess air in the sample, were compared with the atmospheric mixing ratios of the three CFC compounds from 1940 to 2005 (fig. 6) to infer the age of each water sample (Eurybiades Busenberg and L.N. Plummer, U.S. Geological Survey, written commun., 2006; International Atomic Energy Agency, 2006). Interpretations of groundwater age depend on the assumption that concentrations of CFCs are in equilibrium with gases in the soil and that concentrations of CFCs in infiltrating water are equal to those in the atmosphere (International Atomic Energy Agency, 2006).

A water sample from a well represents a mixture of groundwater from all the flow paths and age dates that contribute to the well screen (Plummer and others, 2003). Interpretation of groundwater-age dates and the potential transport of associated contaminants are affected by the source of recharge to the contributing flow paths and the hydraulic conductivity and porosity characteristics of an aquifer (International Atomic Energy Agency, 2006). Two models, piston flow and binary mixing, were used to represent some of the variation in age dates in groundwater. Computation of reliable groundwater ages requires that all concentrations of $\mathrm{CFCs}$ are reliable, they have not been decreased through degradation, and they have not increased to anomalously large values by introduction of contamination.

In some cases, a groundwater sample can be described as flowing along a discrete path and is unaffected by mixing processes from where it recharges an aquifer to where it is sampled from the screened interval of the well; this situation is called "piston flow" (International Atomic Energy Agency, 2006, p. 6). A determination that a piston-flow model describes the flow of groundwater from recharge to the well also assumes that the well screen is short and does not produce water from a variety of recharge sources and flow paths. Interpretation of groundwater-age dates is simpler with a piston-flow model because the concentration of the age-dating tracer also is assumed to be unaffected by mixing or other processes that would change the concentration of the tracer.
Piston flow is most likely to occur when recharge occurs in a small area, such as through a sinkhole or through a thinner part of a confining-till unit, and when an aquifer is very thin or composed of conduit-like or fractured-and-solution-enhanced flow paths. For example, flow through a network of discrete or interconnected fractures or solution-modified features, such as in fractured or dissolution-modified carbonate rock or karst (Smart and Hobbs, 1986) could be described by piston flow.

Another type of model, binary mixing, represents a groundwater sample as a mixture of old (pre-CFC or CFCfree) water and young water that infiltrated to the aquifer after CFCs were introduced to the environment. The simple dilution of young water with old, CFC-free water enables the age of the young water to be computed using the atmospheric ratios of two CFCs in the water sample (Plummer and others, 2003).

Examples of interpreting age dates of groundwater samples using the concentration of three CFC compounds relative to piston-flow and binary-mixing models are shown in figure 8 and described below; this discussion is modified and partly reproduced from Plummer and others (2003) and International Atomic Energy Agency (2006). A sample of groundwater that is not affected by mixing with groundwater of different ages (point X, fig. 8A) would plot along piston-flow curves for pairs of CFC atmospheric-mixing ratios. The correspondence of the atmospheric-mixing ratios in groundwater-point $\mathrm{X}$ - to the typical atmospheric composition of the CFC compounds at various times - the piston-flow curve-indicates the age of the groundwater since it infiltrated below the water table. Point X depicts the concentrations of CFC-11 and CFC-12 in a hypothetical groundwater sample collected in 2008 with an age of 22 years that infiltrated below the water table in 1986. Samples that plot off the piston-flow curves and within the area defined by the dashed lines shown in figure 8 can be defined by binary mixtures. For example, point Y plots along a dashed line that represents a binary mixture between young 1985 water (with concentrations of CFC-12 and CFC-113 similar to the 1985 atmosphere) and old, CFC-free water (point Y, fig. $8 \mathrm{~B}$ ). In a binary mixture, the age of the young water, for this study, also represents the minimum age of activities and contamination that could be associated with that water. The proportions of the young and old waters that correspond to the position of point $\mathrm{Y}$ on the mixing line are estimated by the lever rule (Levine, 1978, p. 294).

Water samples with concentrations of CFCs that have been affected by processes such as sorption, biotransformation, or contamination will plot outside the areas of pistonflow and binary-mixing models. For example, point Y on figure $8 \mathrm{~A}$ indicates a smaller concentration of $\mathrm{CFC}-11$ relative to CFC-12; it is below the piston-flow and binary-mixing areas. Because CFC-12 typically is more stable and less affected by processes such as sorption or biotransformation, the relative depletion of CFC-11 in the composition represented by point $\mathrm{Y}$ would be attributed to degradation in the aquifer by biogeochemical processes. In comparison, point $\mathrm{X}$ on figure $8 \mathrm{~B}$ contains a larger concentration of CFC-113 relative to CFC-12 and plots above the piston-flow and binary-mixing areas. The 

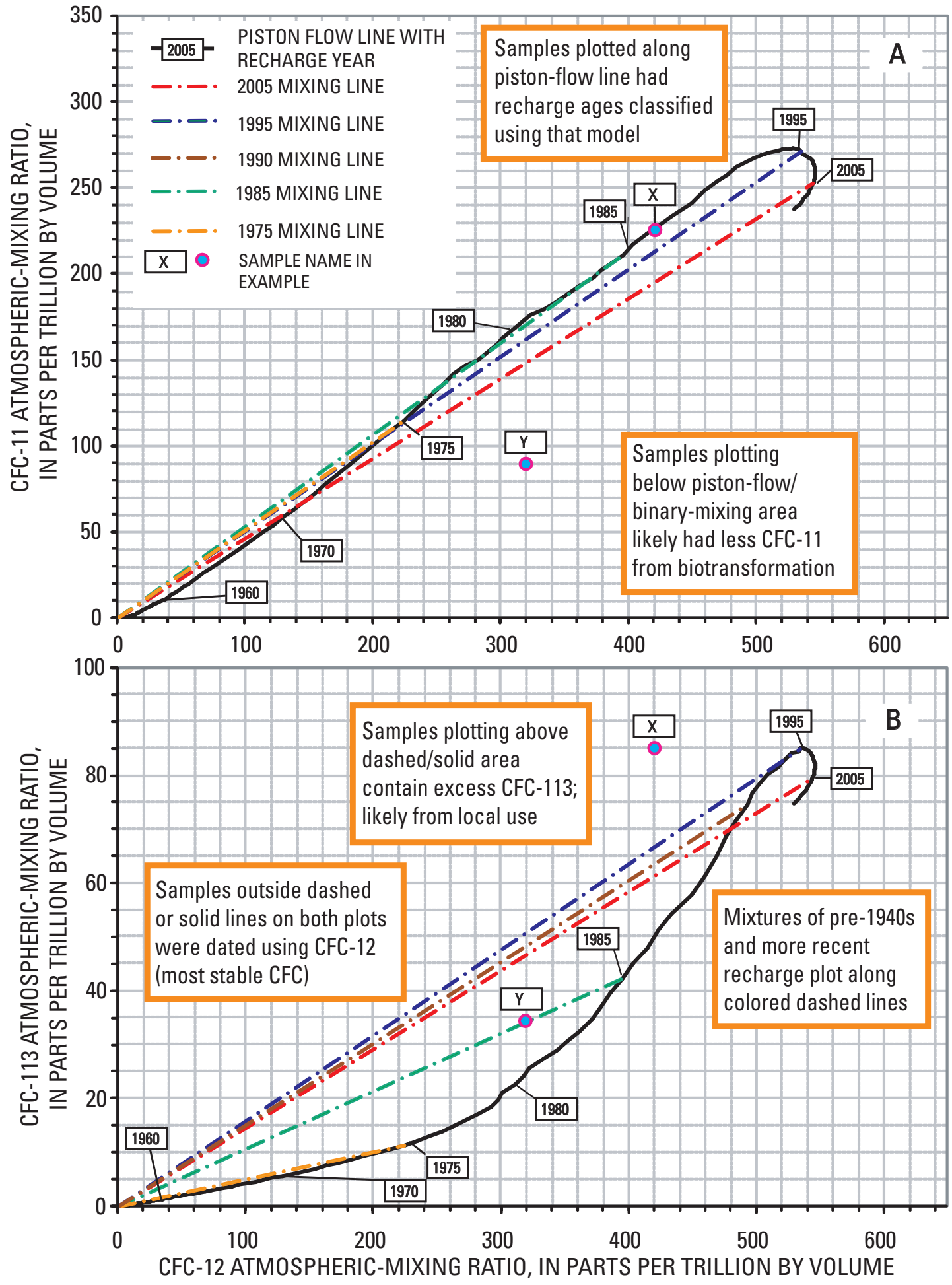

Figure 8. Examples of interpreting age dates of groundwater samples using the atmospheric-mixing ratios of chloroflurocarbon (CFC) compounds relative to piston-flow and binary-mixing models: A. CFC-11 and CFC-12 and B. CFC-113 and CFC-12. Abundances of CFC-11, CFC-12, and CFC-113 are shown as continuous curves corresponding to different groundwater-mixing models: (1) Thin solid lines (including point " $X$ ") indicate compositions of discrete water parcels with single ages (corresponds to the "piston-flow" or no-mixing model); (2) Dashed lines of different colors (including point " $Y$ ") indicate compositions of binary mixtures with varying fractions of "young" water with recharge compositions of 2005, 1995, 1990, 1985, and 1975 and "old" water that has no detectable CFC compounds (pre-1940 water). Dates (years) indicated along the piston-flow line (1) correspond to atmospheric-mixing ratios of CFC-11, CFC-12, and CFC-113 in precipitation from the identified years. 
apparent excess of CFC-113 in the composition represented by point $\mathrm{X}$ on figure $8 \mathrm{~B}$ would be attributed to contamination from an external source.

\section{Preliminary Hydrogeologic Framework of Till and Carbonate Bedrock Hydrogeologic Units}

This section presents a preliminary description of the hydrogeologic framework of the till and carbonate bedrock hydrogeologic units and groundwater flow to provide a context for presentation and interpretation of the age-dating results. A more comprehensive presentation and analysis of geologic and hydrologic data collected to describe the detailed hydrogeologic framework of the DU Impact Area is in preparation as of April 2009 by the Army and Science Applications International Corporation. That effort may modify some of these preliminary observations on that framework.

A synoptic groundwater level measurement was made by SAIC personnel on April 7, 2008, immediately before the collection of groundwater samples described in this investigation (table 5, at end of report). Groundwater levels also were occasionally collected from many of these wells by USGS personnel during June 2007-August 2008 (table 5). March through August are locally the months with the largest average precipitation, ranging from about $4.1 \mathrm{in} / \mathrm{month}$ in August to $4.96 \mathrm{in} /$ month in May (Midwestern Regional Climate Center, 2009b). Precipitation at a Big Oaks National Wildlife Refuge weather station (BIGI3), about 2 mi northwest of the study area (fig. 2), was 13.42 in. during the March that preceded sampling (National Weather Service, 2008); this was considerably wetter than the normal average precipitation for March of 4.26 in. (1971-2000 period, Midwestern Regional Climate Center, 2009b) and wetter than any other month during the September 2007-September 2008 period (fig. 9).

Groundwater-flow directions and vertical gradients between water-bearing intervals were interpreted to provide a preliminary framework to estimate groundwater ages and water-chemistry data. Water-level contours were compiled from a set of synoptic groundwater level measurements made on April 7, 2008, from wells in the Pre-Wisconsinan till, shallow carbonate unit, and deep carbonate unit (figs. 10-12) to interpret water-level gradients and the directions of flow potentials (the direction of the water-level gradient) that prevailed immediately before sampling.

The water table in the Pre-Wisconsinan till is contoured in discontinuous parts because the till was encountered in upland areas between incised stream valleys and is not present or thin along several stream valleys (fig. 10). Groundwaterlevel gradient directions generally were toward the local surface-water drainage. North of Big Creek, the gradient directions are westward toward a tributary of Big Creek and southward toward Big Creek. Groundwater-gradient directions in the Pre-Wisconsinan till south of Big Creek are south and southwestward toward Middle Fork Creek and northward toward Big Creek (fig. 10).

Vertical gradients generally were downward from the Pre-Wisconsinan till into the shallow carbonate unit at paired wells JPG-DU-04O and JPG-DU-04I, JPG-DU-06O and JPGDU-06I, and JPG-DU-09O and JPG-DU-09I (table 6, at end of report). Vertical gradients most often were upward from the shallow carbonate unit into the Pre-Wisconsinan till at paired wells JPG-DU-03O and JPG-DU-03I and at paired wells JPGDU-10O and JPG-DU-10D (table 6).

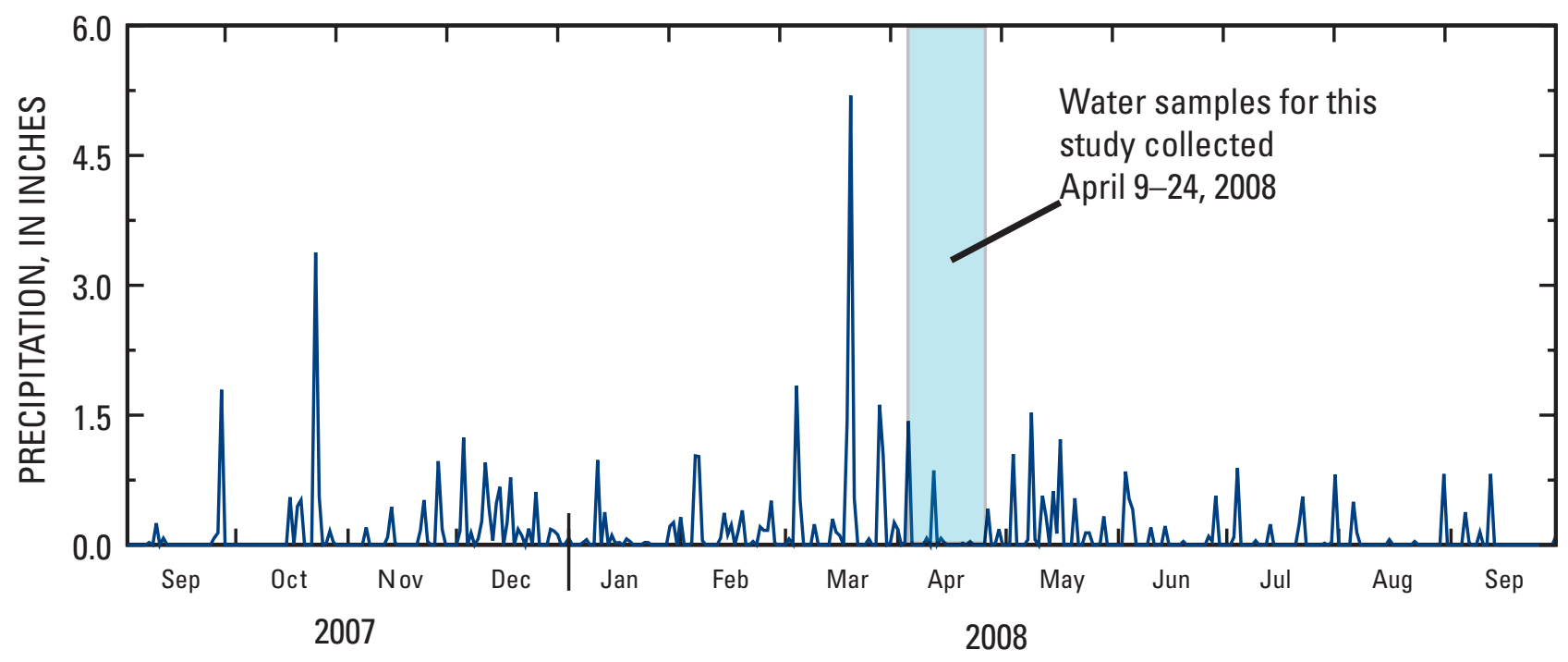

Figure 9. Precipitation at a Big Oaks National Wildlife Refuge weather station about 5 miles northwest of the study area at Jefferson Proving Ground, southeastern Indiana, September 2007 to September 2008. 


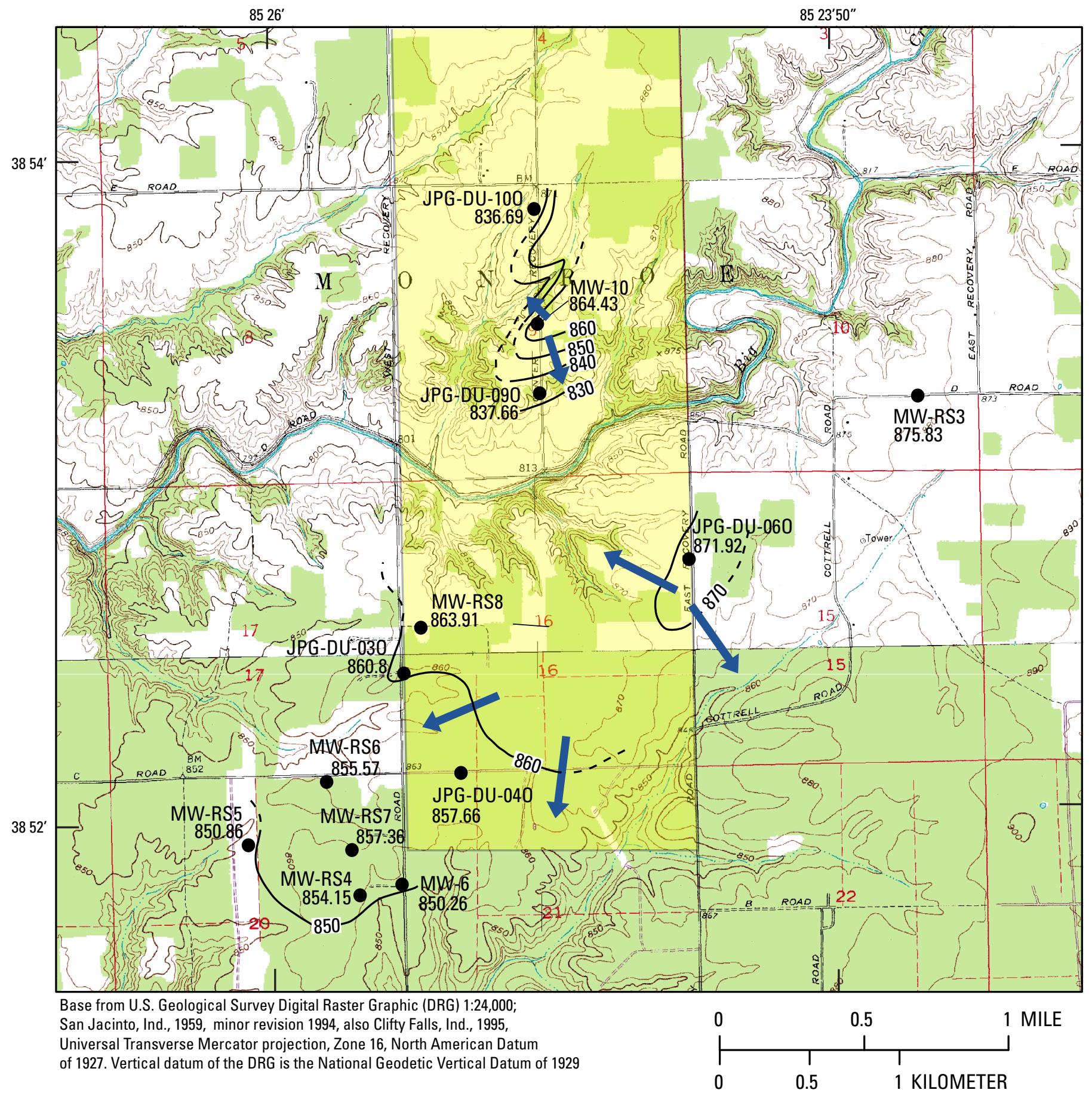

\section{EXPLANATION}

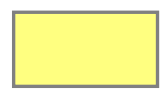

DEPLETED URANIUM IMPACT AREA—Approximate extent

- 860 - WATER-LEVEL CONTOUR-Approximate altitude of the water level in the Pre-Wisconsinan till, April 7, 2008, in feet above North American Vertical Datum of 1988. Dashed where approximately located. Contour interval 10 feet

MW-RS4 GROUNDWATER OBSERVATION WELL--With well identifier and water level in the Pre-Wisconsinan till, April 7, 2008, 854.15 in feet above North American Vertical Datum of 1988.

\section{INFERRED DIRECTION OF WATER-LEVEL GRADIENT IN THE PRE-WISCONSINAN TILL}

Figure 10. Altitude of the water table in the Pre-Wisconsinan till, April 7, 2008, at the Jefferson Proving Ground, southeastern Indiana. 


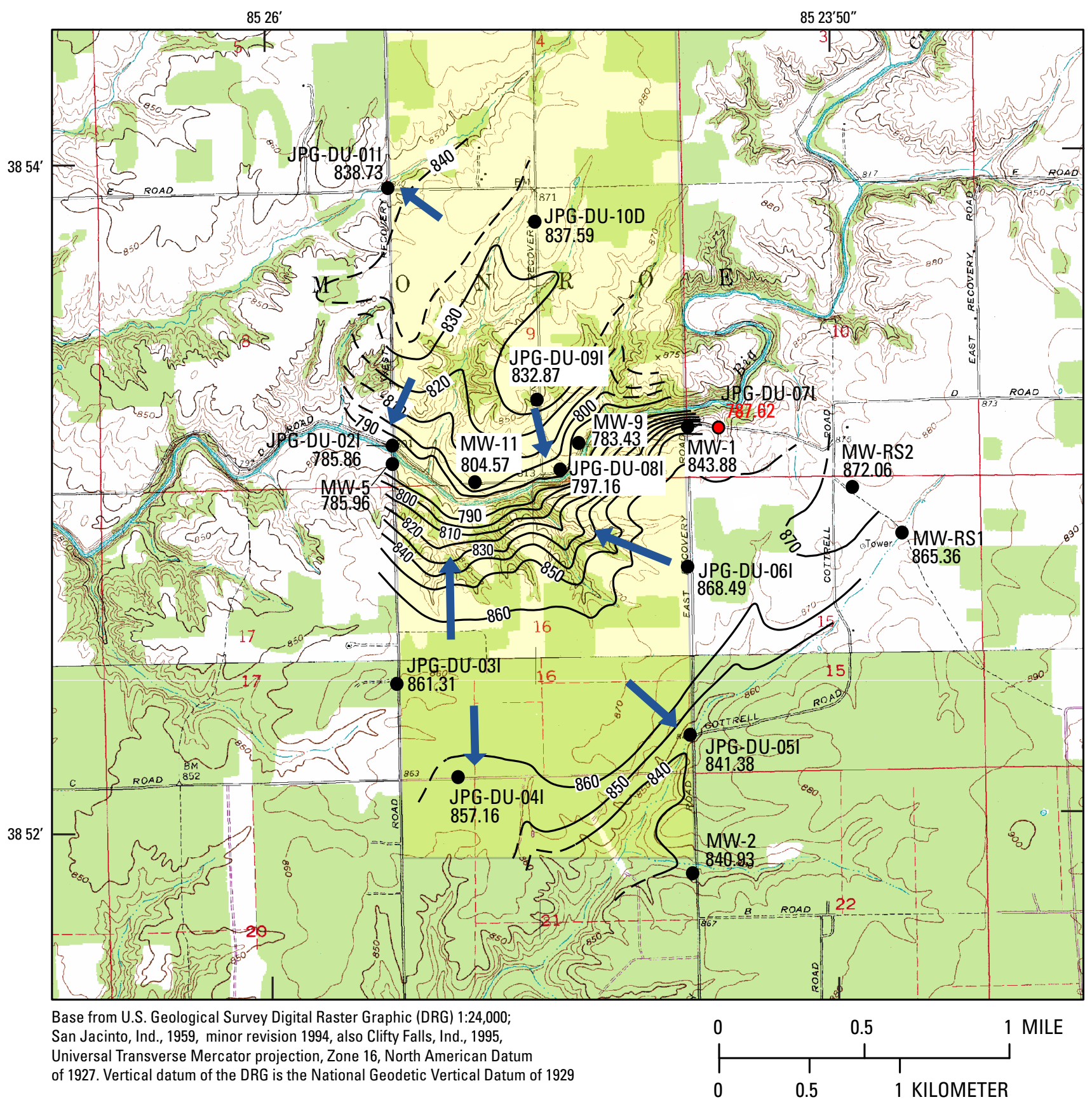

\section{EXPLANATION}

DEPLETED URANIUM IMPACT AREA-Approximate extent

- 830- WATER-LEVEL CONTOUR-Approximate altitude of the water level in the shallow carbonate unit, April 7, 2008, in feet above North American Vertical Datum of 1988. Dashed where approximately located. Contour interval 10 feet.

JPG-DU-01I G GROUNDWATER OBSERVATION WELL--With well identifier and water level in the shallow carbonate unit, April 7, 2008, in feet above North American Vertical Datum of 1988.

JPG-DU-07I GROUNDWATER OBSERVATION WELL--With well identifier and water level in well in the shallow carbonate unit 787.62 indicating dry condition, April 7, 2008, in feet above North American Vertical Datum of 1988.

INFERRED DIRECTION OF WATER-LEVEL GRADIENT--Direction of groundwater flow may differ because of irregular distribution of interconnected porosity in the shallow carbonate unit

Figure 11. Altitude of groundwater levels in the shallow carbonate unit, April 7, 2008, at the Jefferson Proving Ground, southeastern Indiana. 


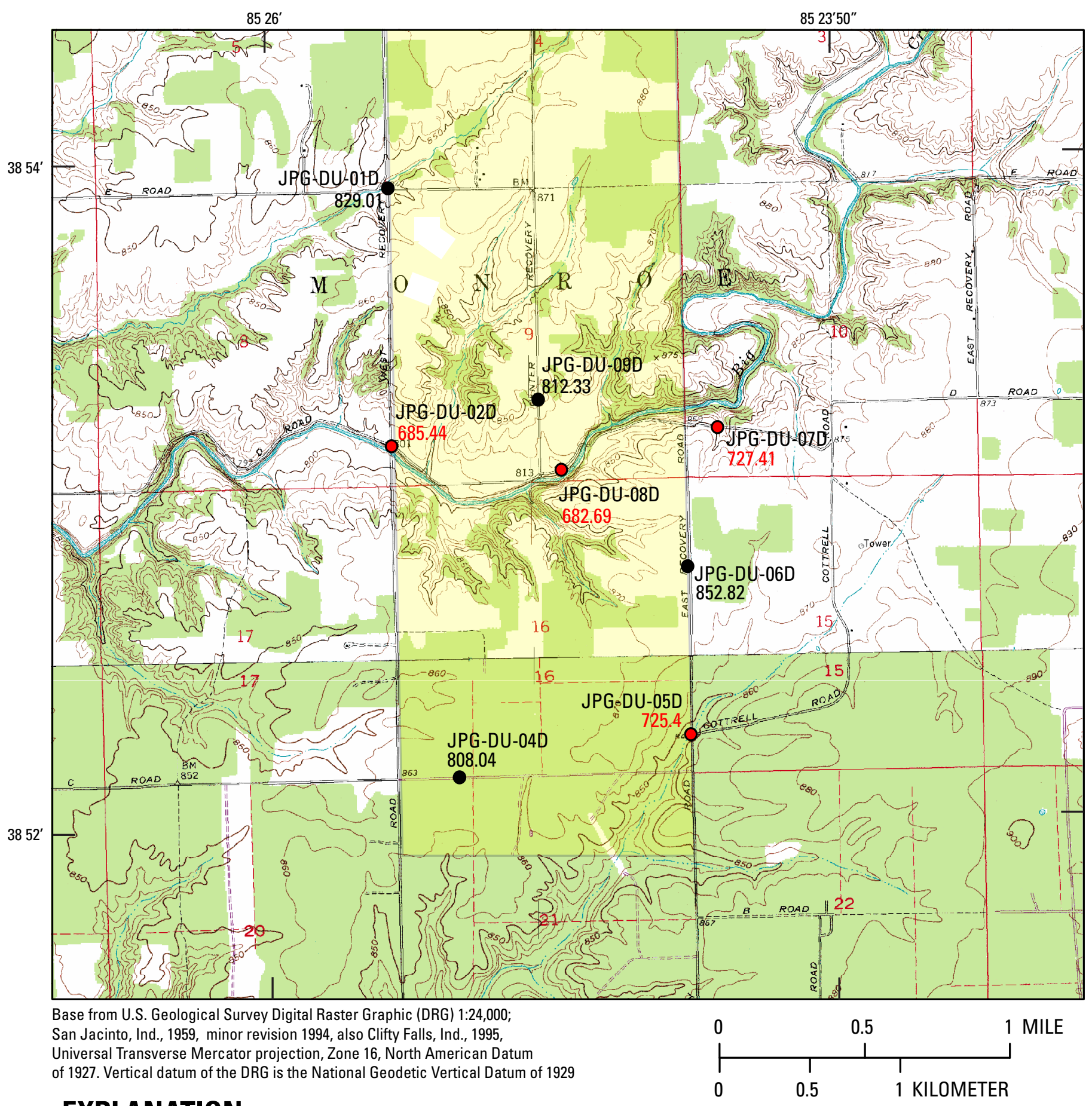

\section{EXPLANATION}

DEPLETED URANIUM IMPACT AREA-Approximate extent

- JPG-DU-04D GROUNDWATER OBSERVATION WELL-With well identifier and water level in the deep carbonate unit, 808.04 April 7, 2008, in feet above North American Vertical Datum of 1988.

- JPG-DU-05D GROUNDWATER OBSERVATION WELL-With well identifier and water level in well screened in the 725.4 deep carbonate unit indicating dry condition, April 7, 2008, in feet above North American Vertical Datum of 1988.

Figure 12. Altitude of groundwater levels in the deep carbonate unit, April 7, 2008, at the Jefferson Proving Ground, southeastern Indiana. 
Groundwater-level gradient directions in the shallow carbonate unit were toward local surface-water drainages and generally from areas of higher groundwater levels in interstream areas toward discharge areas near Big Creek, Middle Fork Creek, and their tributaries (fig. 11). The April 7, 2008, water levels in the shallow carbonate unit are contoured as a continuous surface, although the distribution of conductive fractures and dissolution modified zones in the unit is considered by this study to be heterogeneous and discontinuous.

Vertical gradients from the shallow carbonate unit toward the deep carbonate unit at 3 of 4 paired wells and slow or no recovery of water levels in wells at 4 other sites in the deep carbonate unit indicate a resistance to and lack of flow between the two units and that the directions of flow in the shallow carbonate unit principally are horizontal (table 6). Vertical gradients were downward from the shallow carbonate unit toward the deep carbonate unit at two sites with paired wells with relatively stable water levels; at JPG-DU-06I and JPG-DU-06D and at JPG-DU-09I and JPG-DU-09D (tables 5 and 6$)$. The gradients at these sites ranged from $0.106 \mathrm{ft} / \mathrm{ft}$ downward between wells JPG-DU-06I and JPG-DU-06D to $0.655 \mathrm{ft} / \mathrm{ft}$ downward between wells JPG-DU-06I and JPGDU-06D for data collected between January and August of 2008.

Vertical gradients were also likely downward between wells JPG-DU-04I and JPG-DU-04D (table 6). Because water levels did not fully stabilize between sampling-related changes in well JPG-DU-04D (table 5), the magnitude of the long-term vertical gradients between these wells cannot be evaluated with available data. In contrast, as water levels recovered from 35.23 to $-0.58 \mathrm{ft}$ below the land surface datum in JPG-DU01D from January through August 2008, vertical gradients gradually changed from downward to slightly upward between paired wells JPG-DU-01I and JPG-DU-01D (tables 5 and 6). The slow recovery or non-recovery of water levels in most wells in the deep carbonate unit however, was consistent with a very low horizontal hydraulic conductivity in most parts of that unit.

Water levels in deep wells at three other well pairs, notably JPG-DU-02D, JPG-DU-05D, and JPG-DU-08D, did not substantially recover after groundwater was withdrawn during initial well development (fig. 3 and table 5). The vertical hydraulic gradients between well pairs JPG-DU-02I and JPG-DU-02D, JPG-DU-05I and JPG-DU-05D, and JPG-DU08I and JPG-DU-08D indicate a poor hydraulic connection between the shallow and deep carbonate units. The lack of post development recovery of water levels at wells JPG-DU02D, JPG-DU-05D, JPG-DU-07D, and JPG-DU-08D in the deep carbonate unit indicate that parts of that unit have little or no permeability.

Groundwater-flow directions in the deep carbonate unit could not be determined because of the heterogeneous distribution of permeable zones, as indicated by the several dry wells in this unit (fig. 12) and the slow recovery of water levels at several wells. The heterogeneous distribution of permeable zones in the deep carbonate encountered during well drilling indicate that groundwater occurrence and flow may be limited to sparse, poorly connected joints and bedding plane separations with little solution enhancement. The slow recovery of water levels after post drilling development in wells open to the deep carbonate unit indicate these water bearing zones have a low hydraulic conductivity and collectively contribute little to groundwater transmission laterally across the deep carbonate.

Recharge to wells screened in Pre-Wisconsinan till was assumed principally to represent vertical flow to the saturated zone sampled by the well. Groundwater level measurements and land-surface altitudes were used to assign a recharge altitude to water from each well for recharge temperature and CFC-based age-dating computations (table 5). The recharge altitudes of water from wells screened in Pre-Wisconsinan till were assumed to be similar to the observed groundwater levels from those wells, rounded to the nearest $5 \mathrm{ft}$; these recharge altitudes ranged from $840 \mathrm{ft}$ above the vertical datum for well JPG-DU-09O to $870 \mathrm{ft}$ above the vertical datum for well JPGDU-06O (table 5).

Groundwater recharge to wells that were open to the shallow and deep carbonate units likely occurred upgradient from the well and at higher water-level altitudes than the sampled depth. Recharge altitudes used for dissolved gas and CFCbased groundwater-age computations for water from wells in the shallow carbonate unit ranged from $810 \mathrm{ft}$ above the vertical datum for well JPG-DU-02I to $870 \mathrm{ft}$ above the vertical datum for well JPG-DU-06I (table 5). Recharge altitudes for water from two wells in the deep carbonate unit were assigned to be similar to those used for adjacent wells in the shallow carbonate unit; they were $840 \mathrm{ft}$ above the vertical datum for well JPG-DU-09D and $870 \mathrm{ft}$ above the vertical datum for well JPG-DU-06D (table 5).

\section{General Groundwater Chemistry and Evaluation of Oxidation-Reduction Conditions}

Field water-quality parameters were measured by SAIC representatives during the sampling of 15 wells in and near the DU Impact Area (table 7). The values of these parameters are reported to provide a context for the USGS samples analyzed for dissolved gases, tritium, and CFCs. The data reported here represent a one-time sampling of the wells; other sampling was done in 2008 and 2009 by SAIC. Water-quality parameters measured in water from wells sampled for tritium only are not presented in this report.

Water from wells in the deep carbonate unit generally had less dissolved oxygen than water from the wells in the Pre-Wisconsinan till or the shallow carbonate unit. Field measurements of dissolved oxygen ranged from $<0.1 \mathrm{mg} / \mathrm{L}$ in water from wells JPG-DU-09D and JPG-DU-02I to $1.7 \mathrm{mg} / \mathrm{L}$ in water from well JPG-DU-10O (table 7). Three of 5 samples from the Pre-Wisconsinan till and 6 of 8 samples from the shallow carbonate unit had concentrations of dissolved oxygen that ranged from $0.7 \mathrm{mg} / \mathrm{L}$ to $1.7 \mathrm{mg} / \mathrm{L}$. These concentrations 
Table 7. Values of field-determined water-quality parameters in groundwater samples from the Jefferson Proving Ground, southeastern Indiana, April 2008.

$\left[\mathrm{mm} / \mathrm{dd} / \mathrm{yy}\right.$, month/day/year; hhmm, hours and minutes; ${ }^{\circ} \mathrm{C}$, degrees Celsius; $\mu \mathrm{S} / \mathrm{cm}$, microsiemens per centimeter; NTU, Nephelometric Turbidity Units, as reported by Science Applications International Corporation; $\mathrm{mV}$, millivolt; $\mathrm{mg} / \mathrm{L}$, milligrams per liter; <, less than]

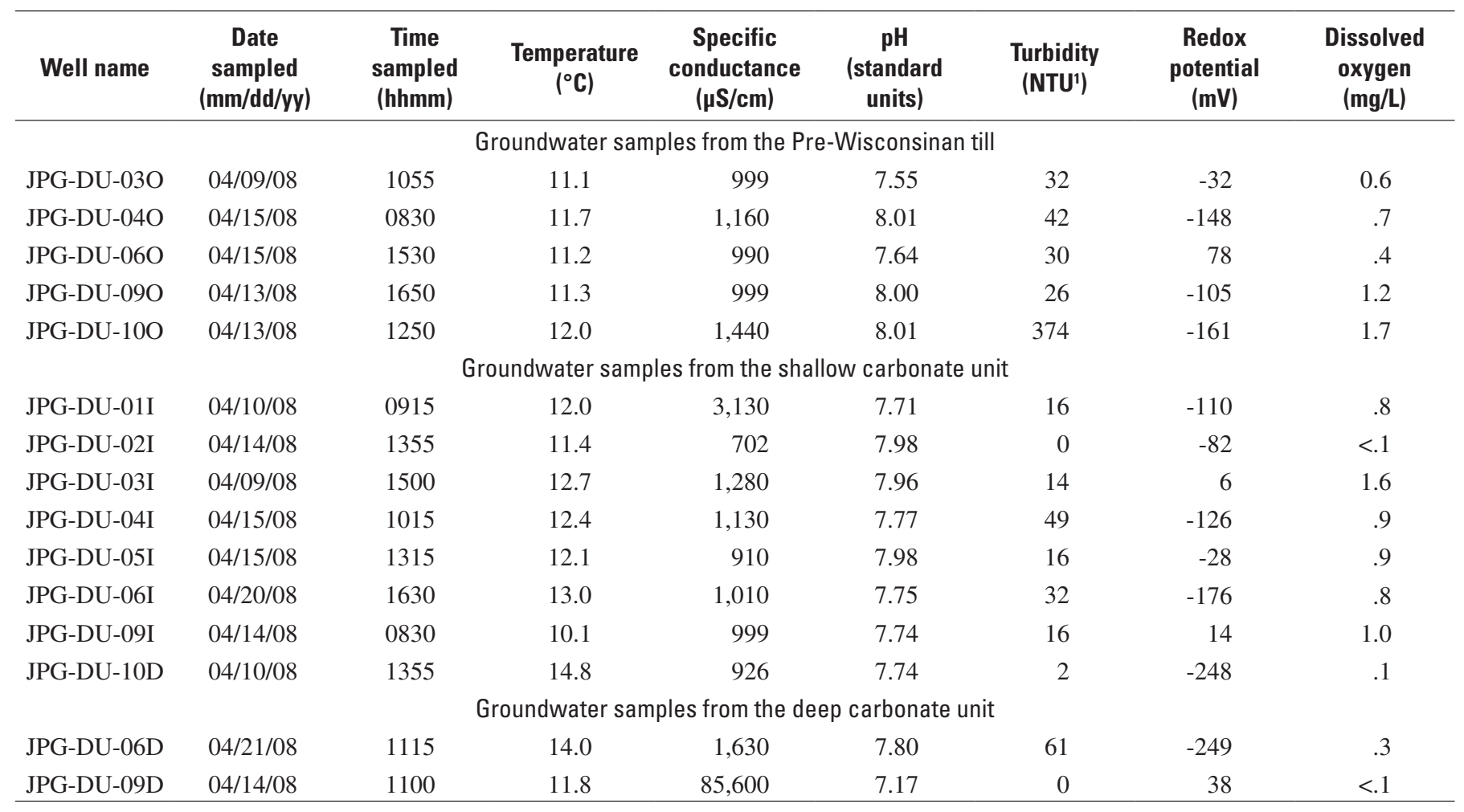

${ }^{1}$ Turbidity values were determined using a Horiba model U-22XD multiparameter unit. That unit was calibrated to report turbidity data in Nephelometric Turbidity Units (NTU; Horiba, Ltd., 2001). U.S. Geological Survey methods described in Anderson (2005) have revised criteria to report turbidity data in Formazin Nephelometric Ratio Units from equipment, such as the model used here, that have a scattered light receptor that is not oriented at 90 degrees to the light source. These data are reported here in units of NTU to be consistent with other reporting of the data by Science Applications International Corporation (2008).

are considered for this study to be sufficiently oxic to support aerobic bacterial processes (Bradley and others 2008; Gossett, 2010); CFC compounds are generally stable under oxic conditions (International Atomic Energy Agency, 2006). Except for water from wells JPG-DU-02I and JPG-DU-10O, concentrations of dissolved oxygen in water from the shallow carbonate unit ranged from 0.8 to $1.6 \mathrm{mg} / \mathrm{L}$. Water from wells JPG-DU-02I, JPG-DU-10D, and JPG-DU-09D had concentrations of dissolved oxygen that were $0.1 \mathrm{mg} / \mathrm{L}$ or less, which was an indication that they may support anaerobic microbial conditions (Bradley and others, 2008); those conditions, if sufficiently reduced, have the potential to biotransform and decrease concentrations of some CFCs-particularly CFC-11 and CFC-113 (International Atomic Energy Agency, 2006).

Specific-conductance (SC) values were highest in water from one well in the deep carbonate unit (JPG-DU-09D, $85,600 \mu \mathrm{S} / \mathrm{cm}$ ) and the shallow carbonate unit (well JPG-DU01I, 3,130 $\mathrm{SS} / \mathrm{cm}$; table 7). The groundwater level in well JPG-DU-01I generally was above land surface, indicating that the well potentially was developed in a discharge area or a confined part of the shallow carbonate unit. The source of the large SC values in water from well JPG-DU-01I cannot be distinguished using these data. SC values were smallest in water from the shallow carbonate unit (wells JPG-DU-02I, $702 \mu \mathrm{S} / \mathrm{cm}$ and JPG-DU-05I, $910 \mu \mathrm{S} / \mathrm{cm}$ ); these wells are located next to streams that are incised into carbonate bedrock and have less than $5 \mathrm{ft}$ of overlaying soil or Pre-Wisconsinan till deposits. SC measures the fluid electrical conductivity; SC values relate to the types and quantities of dissolved substances in water, but there is no universal linear relation between concentrations of dissolved solids and SC (Radtke and others, 2005).

The $\mathrm{pH}$ values of the 15 groundwater samples reported in table 7 were alkaline. The $\mathrm{pH}$ of groundwater in the study area ranged from 7.17 at a well (JPG-DU-09D) in the deep carbonate unit to 8.01 at two wells (JPG-DU-04O and JPG-DU-10O) in the Pre-Wisconsinan till. No trends in $\mathrm{pH}$ with depth or across the study area were noted.

\section{Concentrations of Dissolved Gas and Estimated Average Recharge Temperatures}

Estimated average recharge temperatures of groundwater indicate that most recharge to groundwater in the study area 
occurs during the cooler months of fall, winter, and spring seasons when evapotranspiration typically is smallest. Estimated average recharge temperatures of groundwater ranged from $1.5^{\circ} \mathrm{C}$ at well JPG-DU-04O to $11.7^{\circ} \mathrm{C}$ at well JPG-DU-3I; the median recharge temperature was $7.1^{\circ} \mathrm{C}$ (table 8). These estimated average recharge temperatures were less than $12.6^{\circ} \mathrm{C}$, the mean monthly air temperature at Madison, Indiana (Midwestern Regional Climate Center, 2009a). Most wells had estimated average recharge temperatures that were $8.6^{\circ} \mathrm{C}$ or less; these corresponded to the range of monthly average air temperatures at Madison, Indiana, from November to March $\left(-0.7^{\circ} \mathrm{C}\right.$ to $7.4^{\circ} \mathrm{C}$; Midwestern Regional Climate Center, 2009a) and indicated that most recharge occurred during the cooler, non-growing months. Absolute differences between the estimated average recharge temperatures computed for groundwater samples (table 8) and sequential replicate samples (table 9, at end of report) were very small; they ranged from no difference for well JPG-DU-03I to $0.7^{\circ} \mathrm{C}$ for well JPG-DU-3I. Excess concentrations of air in water from 13 of 15 wells sampled for dissolved gases ranged from $1.7 \mathrm{~cm}^{3} / \mathrm{L}$ in water from well JPG-DU-02I to $13.7 \mathrm{~cm}^{3} / \mathrm{L}$ in water from well JPG-DU-04I (table 8). Recharge altitudes in table 5 were used to normalize the concentrations of argon and nitrogen gas to standard pressure (760 mm of mercury).

Nitrogen and argon concentrations for wells JPG-DU06D and JPG-DU-09D produced estimated average recharge temperatures of 16.9 and 13.7 , which were greater than the mean monthly air temperature of $12.6^{\circ} \mathrm{C}$ at Madison, Indiana. Concentrations of argon in groundwater from wells JPG-DU06D and JPG-DU-09D were the smallest of all groundwater sampled during this investigation (table 8). These recharge temperatures assume that excess nitrogen, relative to the smaller concentrations of argon, is present in water from the two wells; $3.8 \mathrm{mg} / \mathrm{L}$ for well JPG-DU-06D and $11.5 \mathrm{mg} / \mathrm{L}$ for well JPG-DU-09D. Water from well JPG-DU-06D had the largest concentration of methane of any sample collected during this study $\left(11.4 \mathrm{mg} / \mathrm{L}\right.$ as $\mathrm{CH}_{4}$; table 8$)$ and a small concentration of carbon dioxide $\left(17.1 \mathrm{mg} / \mathrm{L}\right.$ as $\left.\mathrm{CO}_{2}\right)$, indicating the likely prevalence of reduced, methanogenic conditions that also could have generated excess nitrogen. Water from well

Table 8. Concentrations of selected dissolved gases in water samples from the Jefferson Proving Ground, southeastern Indiana, April 2008.

$\left[\mathrm{mm} / \mathrm{dd} / \mathrm{yy}\right.$, month/day/year; hhmm, hours and minutes; mg/L, milligrams per liter; $\mathrm{cm}^{3} / \mathrm{L}$, cubic centimeters per liter; ${ }^{\circ} \mathrm{C}$, degrees Celsius; Q, estimated concentration; --, not computed]

\begin{tabular}{|c|c|c|c|c|c|c|c|c|c|c|c|}
\hline Well name & $\begin{array}{c}\text { Date } \\
\text { sampled } \\
(\mathrm{mm} / \mathrm{dd} / \mathrm{yy})\end{array}$ & $\begin{array}{c}\text { Time } \\
\text { sam- } \\
\text { pled } \\
\text { (hhmm) }\end{array}$ & $\begin{array}{c}\text { Methane } \\
\text { (mg/L) }\end{array}$ & $\begin{array}{c}\text { Carbon } \\
\text { dioxide } \\
\text { (mg/L) }\end{array}$ & $\begin{array}{l}\text { Argon } \\
\text { (mg/L) }\end{array}$ & $\begin{array}{c}\text { Nitro- } \\
\text { gen } \\
\text { (mg/L) }\end{array}$ & $\begin{array}{c}\text { Argon, } \\
\text { normal- } \\
\text { ized to } \\
760 \mathrm{~mm} \\
\text { mercury } \\
\text { (mg/L) }\end{array}$ & $\begin{array}{c}\text { Nitrogen, } \\
\text { normal- } \\
\text { ized to } \\
760 \mathrm{~mm} \\
\text { mercury } \\
\text { (mg/L) }\end{array}$ & $\begin{array}{l}\text { Excess } \\
\text { air } \\
\text { concen- } \\
\text { tration } \\
\left(\mathrm{cm}^{3} / \mathrm{L}\right)\end{array}$ & $\begin{array}{c}\text { Excess } \\
\text { nitro- } \\
\text { gen } \\
\text { concen- } \\
\text { tration } \\
\text { (mg/L) }\end{array}$ & $\begin{array}{l}\text { Estimated } \\
\text { average } \\
\text { recharge } \\
\text { temperature } \\
\left({ }^{\circ} \mathrm{C}\right)\end{array}$ \\
\hline \multicolumn{12}{|c|}{ Groundwater samples from the Pre-Wisconsinan till } \\
\hline JPG-DU-06O & $04 / 15 / 08$ & 1530 & .0054 & 65.8 & .78 & 23.5 & .81 & 24.3 & 5.5 & -- & 8.5 \\
\hline JPG-DU-09O & $04 / 13 / 08$ & 1650 & .022 & 34.9 & .82 & 25.6 & .85 & 26.5 & 7.6 & -- & 8.3 \\
\hline JPG-DU-10O & $04 / 13 / 08$ & 1250 & 2.0 & 38.8 & .79 & 23.2 & .82 & 23.9 & 4.3 & -- & 6.7 \\
\hline \multicolumn{12}{|c|}{ Groundwater samples from the shallow carbonate unit } \\
\hline JPG-DU-04I & $04 / 15 / 08$ & 1015 & .025 & 54.4 & 1.0 & 33.5 & 1.0 & 34.5 & 13.7 & -- & 4.2 \\
\hline JPG-DU-05I & $04 / 15 / 08$ & 1315 & Q.00048 & 23.5 & .85 & 27.7 & .88 & 28.5 & 9.8 & -- & 8.6 \\
\hline JPG-DU-06I & $04 / 20 / 08$ & 1630 & .019 & 59.5 & .82 & 24.4 & .84 & 25.2 & 5.5 & -- & 6.4 \\
\hline JPG-DU-09I & $04 / 14 / 08$ & 0830 & Q.00080 & 42.2 & .81 & 23.8 & .83 & 24.6 & 5.0 & -- & 6.7 \\
\hline JPG-DU-10D & 04/10/08 & 1355 & .013 & 26.1 & .84 & 26.5 & .87 & 27.3 & 8.1 & -- & 7.7 \\
\hline \multicolumn{12}{|c|}{ Groundwater samples from the deep carbonate unit } \\
\hline JPG-DU-06D & $04 / 21 / 08$ & 1115 & 11.4 & 17.1 & .57 & 19 & .59 & 19.7 & 1.0 & 3.8 & 16.9 \\
\hline JPG-DU-09D & $04 / 14 / 08$ & 1100 & .018 & 16.7 & .46 & 23.7 & .48 & 24.5 & .5 & 11.5 & 13.7 \\
\hline
\end{tabular}

Quality assurance data, including analyses of sequential replicate samples, are included in table 12 (at end of report). 
JPG-DU-09D had less than $0.1 \mathrm{mg} / \mathrm{L}$ of dissolved oxygen, an indication of anaerobic microbial conditions that could generate excess nitrogen through a process such as nitrate reduction if sufficient nitrate was present.

All groundwater samples collected during this study contained more terrigenic helium (helium of mineralogic origin) than would permit reliable estimation of groundwaterage dates using the ratio of tritium to the isotope helium-3 $\left({ }^{3} \mathrm{H} /{ }^{3} \mathrm{He}\right.$ ) in water (table 10$)$. Therefore, age dating by the ${ }^{3} \mathrm{H} /{ }^{3} \mathrm{He}$ method was not attempted. Dating of groundwater samples that are mixtures of very old water with submodern recharge by the ${ }^{3} \mathrm{H} /{ }^{3} \mathrm{He}$ method can be complicated if a sample contains a large excess (50 percent or greater) of terrigenic helium from the old fraction (Plummer and others, 2000). Concentrations of dissolved helium in groundwater samples collected during this investigation ranged from 82 x $10^{-9} \mathrm{ccSTP} / \mathrm{g}$ water to $109,500 \times 10^{-9} \mathrm{ccSTP} / \mathrm{g}$ (table 10 ). Modern water in equilibrium with air normally contains less helium, about $46 \times 10^{-9} \mathrm{ccSTP} / \mathrm{g}$ water. The concentrations of helium in groundwater samples collected during this study are substantially greater than the equilibrium concentration plus 50 percent (about $70 \times 10^{-9} \mathrm{ccSTP} / \mathrm{g}$ water), indicating the likelihood of substantial uncertainties if age estimates of the young fraction of mixed groundwater were computed. In a mixture, the ${ }^{3} \mathrm{He} /{ }^{4} \mathrm{He}$ ratio of the terrigenic helium must be known for the particular sample within about 1 percent or better to permit reliable ${ }^{3} \mathrm{H} /{ }^{3} \mathrm{He}$ dating of the young fraction.

\section{Estimates of Groundwater Age from Till and Carbonate Bedrock Hydrogeologic Units}

Estimates of groundwater age were developed from concentrations of tritium (table 11) and from concentrations of CFCs using concentrations of excess air and recharge temperatures determined from dissolved-gas data (tables 9 and 10). In addition, ratios of CFC compounds were used to indicate whether a single, largely unmixed source of water (piston flow) to the well was a feasible explanation for concentrations of CFCs and tritium from a well, as compared with mixing of old (pre-CFC) and young (binary mixing) recharge (tables 12 and 13, at end of report). The sum of the concentrations of tritium and the associated 2-sigma precision of concentrations of tritium in groundwater samples were used to assess the potential for analytical uncertainty to affect tritium-based groundwater age estimates, similar to the procedure used by Bartolino (1997, p. 16). Details of the groundwater-age estimates and the implications for water-quality sampling are presented in the following sections.

\section{Tritium-Based Groundwater Ages}

Samples from two wells, one in the shallow carbonate unit (JPG-DU-10D) and one in the deep carbonate unit

Table 10. Concentrations of helium and neon in water samples from the Jefferson Proving Ground, southeastern Indiana, April 2008.

$\left[\mathrm{mm} / \mathrm{dd} / \mathrm{yy}\right.$, month/day/year; hhmm, hours and minutes; nmol/kg, nanomole per kilogram; cc x 10 $10^{-9} \mathrm{~g}$ of water at STP, $10^{-9}$ cubic centimeters of a dissolved gas per gram of water at standard temperature ( 25 degrees Celsius) and pressure (760 millimeters of mercury); ND, neon concentrations not determined owing to interfering concentrations of helium generally larger than 1,000 nanomoles per kilogram of water; NA, not analyzed]

\begin{tabular}{|c|c|c|c|c|c|c|}
\hline Well name & $\begin{array}{l}\text { Date sampled } \\
\text { (mm/dd/yy) }\end{array}$ & $\begin{array}{c}\text { Time sampled } \\
\text { (hhmm) }\end{array}$ & $\begin{array}{c}\text { Helium } \\
\text { (nmol/kg in } \\
\text { water) }\end{array}$ & $\begin{array}{c}\text { Helium } \\
\left(\left[\mathrm{cc} \times 10^{-9}\right] / \mathrm{g}\right. \\
\text { of water at STP) }\end{array}$ & $\begin{array}{c}\text { Neon } \\
\text { (nmol/kg in } \\
\text { water) }\end{array}$ & $\begin{array}{c}\text { Neon } \\
\left(\left[\mathrm{cc} \times 10^{-9}\right] / \mathrm{g}\right. \\
\text { of water at STP) }\end{array}$ \\
\hline \multicolumn{7}{|c|}{ Groundwater samples from the Pre-Wisconsinan till } \\
\hline JPG-DU-04O & $04 / 15 / 08$ & 0830 & 6.4 & 142 & 19.5 & 436 \\
\hline JPG-DU-06O & $04 / 15 / 08$ & 1530 & 3.6 & 82 & 15.0 & 335 \\
\hline \multicolumn{7}{|c|}{ Groundwater samples from the shallow carbonate unit } \\
\hline JPG-DU-01I & 04/10/08 & 0915 & 1,277 & 28,600 & ND & ND \\
\hline JPG-DU-02I & 04/14/08 & 1355 & 11.0 & 246 & 10.0 & 223 \\
\hline JPG-DU-03I & 04/09/08 & 1055 & 18.8 & 422 & 14.1 & 316 \\
\hline \multicolumn{7}{|c|}{ Groundwater samples from the deep carbonate unit } \\
\hline JPG-DU-06D & $04 / 21 / 08$ & 1115 & NA & NA & NA & NA \\
\hline JPG-DU-09D & 04/14/08 & 1100 & 4,885 & 109,500 & ND & ND \\
\hline
\end{tabular}


Table 11. Concentrations of tritium in groundwater samples from observation wells at the Jefferson Proving Ground, southeastern Indiana, April 2008.

[TU, tritium unit; one tritium unit equals 3.2 picocuries per liter; well identifiers and data where concentrations of tritium were less than or equal to $0.8 \mathrm{TU}$ are shown in bold type; estimated age of groundwater is classified from the concentration of tritium]

\begin{tabular}{|c|c|c|c|c|c|c|}
\hline $\begin{array}{l}\text { Project well } \\
\text { identifier }\end{array}$ & $\begin{array}{c}\text { Date sampled } \\
\text { (month/day/year) }\end{array}$ & $\begin{array}{c}\text { Tritium, } \\
\text { water, } \\
\text { unfiltered } \\
\text { (tritium units) }\end{array}$ & $\begin{array}{c}\text { Tritium, } \\
\text { 2-sigma } \\
\text { precision } \\
\text { (tritium units) }\end{array}$ & $\begin{array}{c}\text { Sum of tritium } \\
\text { in water plus } \\
\text { 2-sigma } \\
\text { precision }\end{array}$ & $\begin{array}{l}\text { Tritium-based estimate } \\
\text { of groundwater age }\end{array}$ & Comments \\
\hline \multicolumn{7}{|c|}{ Pre-Wisconsinan till unit } \\
\hline WELL JPG-DU-03O & $04 / 09 / 2008$ & 4.1 & 0.5 & 4.6 & Substantially modern & -- \\
\hline WELL JPG-DU-04O & $04 / 15 / 2008$ & .5 & .4 & .9 & Submodern & $\begin{array}{l}\text { Sum indicates may be } \\
\text { submodern/modern mix }\end{array}$ \\
\hline WELL JPG-DU-06O & $04 / 15 / 2008$ & 4.6 & .6 & 5.2 & Substantially modern & -- \\
\hline WELL JPG-DU-09O & $04 / 13 / 2008$ & .5 & .6 & 1.1 & Submodern & $\begin{array}{l}\text { Sum indicates may be } \\
\text { submodern/modern mix }\end{array}$ \\
\hline WELL JPG-DU-10O & $04 / 13 / 2008$ & .7 & .6 & 1.3 & Submodern & $\begin{array}{l}\text { Sum indicates may be } \\
\text { submodern/modern mix }\end{array}$ \\
\hline WELL MW-6 & $04 / 15 / 2008$ & 4.6 & .6 & 5.2 & Substantially modern & -- \\
\hline WELL MW-10 & $04 / 23 / 2008$ & 3.3 & .6 & 3.9 & Submodern/modern mix & -- \\
\hline WELL MW-RS3 & $04 / 22 / 2008$ & 5.5 & .8 & 6.3 & Substantially modern & -- \\
\hline WELL MW-RS4 & $04 / 15 / 2008$ & 5.0 & .6 & 5.6 & Substantially modern & -- \\
\hline WELL MW-RS5 & $04 / 14 / 2008$ & 6.6 & .6 & 7.2 & Substantially modern & -- \\
\hline WELL MW-RS6 & $04 / 14 / 2008$ & 7.8 & .8 & 8.6 & Substantially modern & -- \\
\hline WELL MW-RS7 & $04 / 23 / 2008$ & 8.7 & .8 & 9.5 & Substantially modern & -- \\
\hline WELL MW-RS8 & $04 / 24 / 2008$ & 5.0 & .6 & 5.6 & Substantially modern & -- \\
\hline \multicolumn{7}{|c|}{ Shallow carbonate unit } \\
\hline WELL JPG-DU-01I & $04 / 10 / 2008$ & .2 & .4 & .6 & Submodern & -- \\
\hline WELL JPG-DU-02I & $04 / 14 / 2008$ & 5.1 & .6 & 5.7 & Substantially modern & -- \\
\hline WELL JPG-DU-03I & $04 / 09 / 2008$ & 2.6 & .5 & 3.1 & Submodern/modern mix & -- \\
\hline WELL JPG-DU-04I & $04 / 15 / 2008$ & .4 & .4 & .8 & Submodern & -- \\
\hline WELL JPG-DU-05I & $04 / 15 / 2008$ & .3 & .4 & .7 & Submodern & -- \\
\hline WELL JPG-DU-06I & $04 / 20 / 2008$ & .3 & .4 & .7 & Submodern & -- \\
\hline WELL JPG-DU-09I & $04 / 14 / 2008$ & .5 & .6 & 1.1 & Submodern & $\begin{array}{l}\text { Sum indicates may be } \\
\text { submodern/modern mix }\end{array}$ \\
\hline WELL JPG-DU-10D & $04 / 10 / 2008$ & .1 & .6 & .7 & Submodern & -- \\
\hline WELL MW-2 & $04 / 22 / 2008$ & 3.9 & .6 & 4.5 & Submodern/modern mix & May be substantially modern \\
\hline WELL MW-3 & $04 / 22 / 2008$ & 5.0 & .6 & 5.6 & Substantially modern & -- \\
\hline WELL MW-4 & $04 / 15 / 2008$ & 5.3 & .8 & 6.1 & Substantially modern & -- \\
\hline WELL MW-5 & $04 / 25 / 2008$ & 3.7 & .6 & 4.3 & Submodern/modern mix & May be substantially modern \\
\hline WELL MW-8 & $04 / 15 / 2008$ & 4.4 & .6 & 5.0 & Substantially modern & -- \\
\hline WELL MW-11 & $04 / 23 / 2008$ & 4.9 & .6 & 5.5 & Substantially modern & -- \\
\hline \multicolumn{7}{|c|}{ Deep carbonate unit } \\
\hline WELL JPG-DU-06D & $04 / 21 / 2008$ & 3.3 & .6 & 3.9 & Submodern/modern mix & -- \\
\hline WELL JPG-DU-09D & $04 / 14 / 2008$ & $<.1$ & .4 & .5 & Submodern & -- \\
\hline
\end{tabular}


(JPG-DU-09D), had the smallest concentrations of tritium for any samples collected during this study, less than or equal to $0.1 \mathrm{TU}$ (fig. 13; table 11). The tritium-based age dates indicate that the sources of recharge to these wells was submodern and predated 1954. The age dates for these two wells also indicate that water quality from these wells is not affected by the post1984 presence of DU penetrators because recharge from those years has not reached the geologic intervals sampled by the wells.

Four wells in the shallow carbonate unit: JPG-DU-01I, JPG-DU-04I, JPG-DU-05I, and JPG-DU-06I, had concentrations of tritium that were greater than 0.1 but less than or equal to $0.4 \mathrm{TU}$ (fig. 13), indicating that the predominant sources of recharge to these wells also have a submodern age. The range of concentrations of tritium for these four wells, computed by addition or subtraction of the 2-sigma precision with the concentrations of tritium, also were less than or equal to $0.8 \mathrm{TU}$ (table 11). These data indicate that water sampled from these four wells reflect recharge from 1953 or earlier and would not be affected by the post-1984 presence of DU penetrators. A potential presence of modern water in the samples from wells JPG-DU-01I, JPG-DU-04I, and JPG-DU-05I was indicated by the CFC-based age dates; these age classifications are discussed later in this report.

Three wells in the Pre-Wisconsinan till, JPG-DU-04O, JPG-DU-09O, and JPG-DU-10O, and one well in the shallow carbonate unit JPG-DU-09I, had concentrations of tritium that were less than $0.8 \mathrm{TU}$ (fig. 13). However, the sum of concentrations of tritium and the 2-sigma precision of those concentrations for these four wells, overlapped the classification between submodern and submodern/modern mixture age classifications. Although the concentrations of tritium in the samples from these four wells were small $(<0.8 \mathrm{TU})$ and are similar to that of decay-corrected 1953 and earlier precipitation, the possibility of their mixing with submodern water could not be ruled out using analyses of tritium only. Tritiumbased age dates from these four wells were verified using CFC-based age dates.

Concentrations of tritium in groundwater samples from 19 wells ranged from 2.6 to $8.7 \mathrm{TU}$ (table 11), indicating that some or most recharge to these wells, and presumably the associated sources of potential contaminants, reflect activities that post-date 1953 (fig. 13). These samples were classified as having groundwater ages that were substantially modern or a submodern/modern mix. The range of concentrations of tritium in these wells also was slightly less than or nearly equal to the range of annual average decay-corrected concentrations of tritium in post-1972 precipitation from the Ohio River Basin of 3.9 to $8.1 \mathrm{TU}$ (fig. 13). Water from well MW-10 in the Pre-Wisconsinan till unit, wells JPG-DU-03I, MW-2, and MW-5 in the shallow carbonate unit, and JPG-DU-06D in the deep carbonate unit had concentrations of tritium that were slightly less than the decay-corrected post-1972 precipitation. Tritium concentrations in water from these five wells likely represent a mixture of modern water with some fraction of submodern, tritium-depleted water. The possibility of 1984 and later recharge contributing to the modern component of recharge classified in several JPG-DU wells is evaluated later in this report using CFC-based age dates.

The possibility that the MW and MW-RS series wells could produce groundwater containing recharge from the 1984 and later period affected by DU testing cannot be ruled out solely using tritium data. MW and MW-RS series wells were sampled for tritium and were not sampled for CFCs; these wells have age classifications that include some modern recharge. Tritium-based age classifications therefore indicate that water quality from the post-1984 testing period of DU penetrators could be monitored from these wells.

\section{Chlorofluorocarbon-Based Groundwater Ages}

Chlorofluorocarbon-based groundwater ages were computed using two hypothetical flow scenarios; a pistonbased model that assumes no mixing during groundwater flow between recharge and the well screen and a binary-mixing hypothesis that represents the final water composition as a mixture between pre-CFC age (pre-1940) and post-1940 or younger groundwater (tables 12 and 13). CFC-based estimates of groundwater age in several samples from wells in the shallow carbonate and deep carbonate units indicated piston-flow and binary mixtures that predated the use of DU penetrators at JPG. Results from other wells indicated the presence of water with groundwater ages that were partially or entirely from, during, or after about 1980 (table 13). Results of these estimates can be used to evaluate groundwater monitoring targeted to identify water-quality effects dating from or after 1984.

\section{Pre-Wisconsinan Till Groundwater-Age Dates}

The CFC-based age dates of groundwater samples from five wells in the Pre-Wisconsinan till could be explained best as binary mixtures of young (mid-1970s or more recent in age) and old, pre-1940, pre-CFC recharge (figs. 14 and 15; table 13). For example, water from wells JPG-DU-03O and JPG-DU-06O were best represented as binary mixtures of recharge from about 1984 and 1979, respectively, and pre1940 recharge, based on atmospheric-mixing ratios of CFC113 and CFC-12 (fig. 14). The contribution of mid-1980s era recharge to the computed binary mixture was about 70 percent of the sample from well JPG-DU-03O (fig. 15; table 13). The contribution of late-1970s era recharge to the computed binary mixture was about 30 percent of the sample from well JPG-DU-06O (fig. 15; table 13). The CFC-based age estimates of these two samples were consistent with their tritium-based age estimates (table 13); they indicate that wells JPG-DU-03O and JPG-DU-06O may produce groundwater that partly includes recharge that is close in time to the early period of DU-projectile testing at JPG. Based on the CFCage dates and their locations relative to the DU Impact Area, wells JPG-DU-03O and JPG-DU-06O are suitable to monitor 

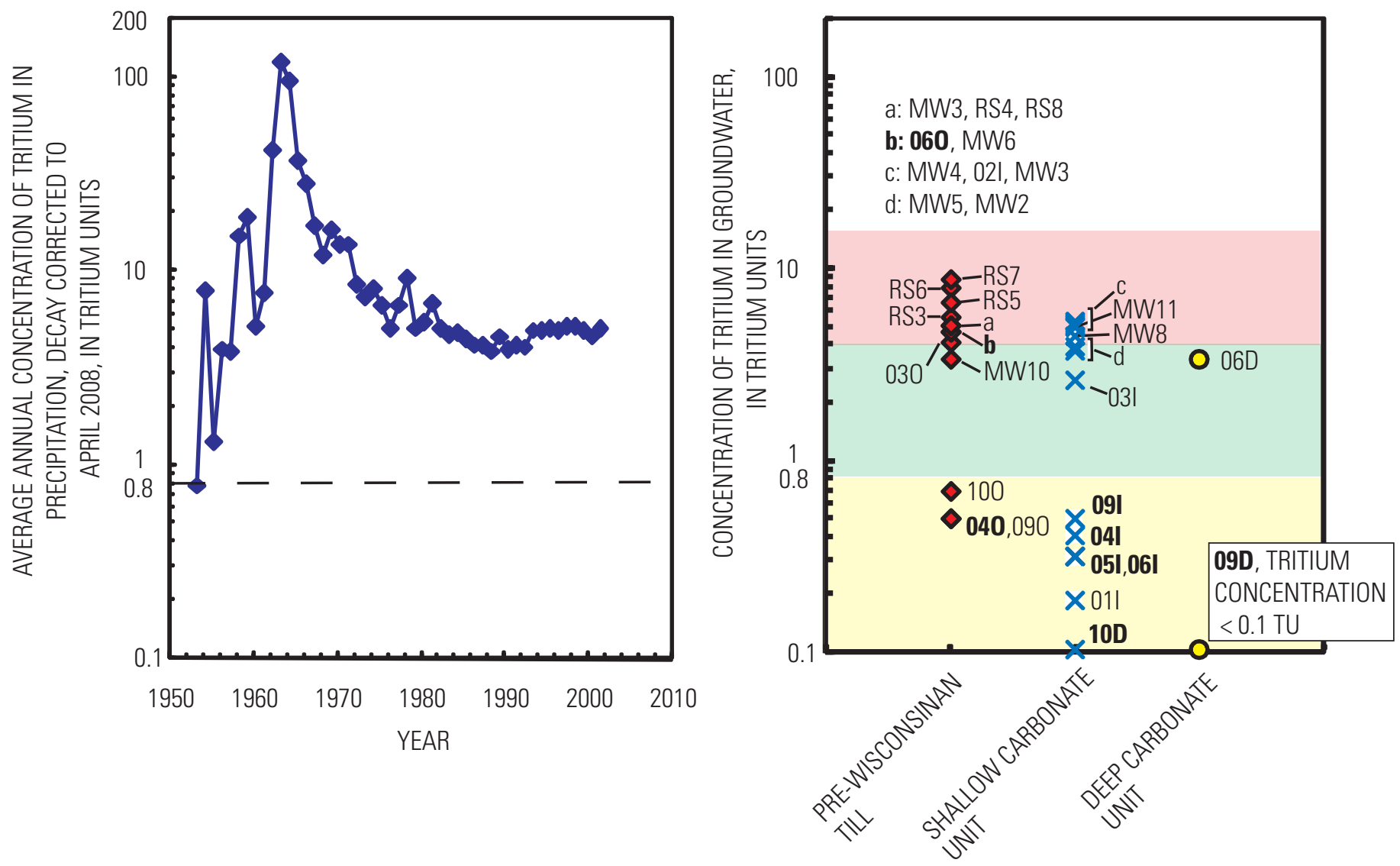

\section{EXPLANATION}

Groundwater-age classification based on tritium concentrations

Substantially modern-Concentrations of tritium ranging from 4 to 15 tritium units (TU). Indicates groundwater is predominantly post-1953 recharge, If tritium ranges from 4 to $8 \mathrm{TU}$, may be mostly post-1972 recharge

Submodern-modern mix - Concentrations of tritium ranging from 0.9 to less than 4 TU. Indicates groundwater is a mixture of submodern recharge with modern, post-1953 recharge

Submodern-Concentrations of tritium ranging from $<0.1$ to 0.8 tritium units. Indicates groundwater is predominantly composed of 1953 or earlier recharge

Groundwater sample-Plotted with last 3 to 4 characters and numbers of local well identifier, as in table 2. Well identifiers in bold font (10D) indicate that the chlorofluorocarbon-based groundwater age of the water sample from the well substantially predates depleted uranium projectile firing at Jefferson Proving Ground (pre-1984).

$\begin{array}{ll}\diamond 030 & \text { Sample from Pre-Wisconsinan till } \\ \times \mathbf{1 0 0} & \text { Sample from shallow carbonate unit } \\ \text { O 09D } & \text { Sample from deep carbonate unit }\end{array}$

Figure 13. Estimates of the average annual concentration of tritium in precipitation for the Ohio River Basin, 1953-2002, corrected for radioactive decay to April 2008, as compared with concentrations of tritium in groundwater samples in the study area at Jefferson Proving Ground, southeastern Indiana, 2008. 


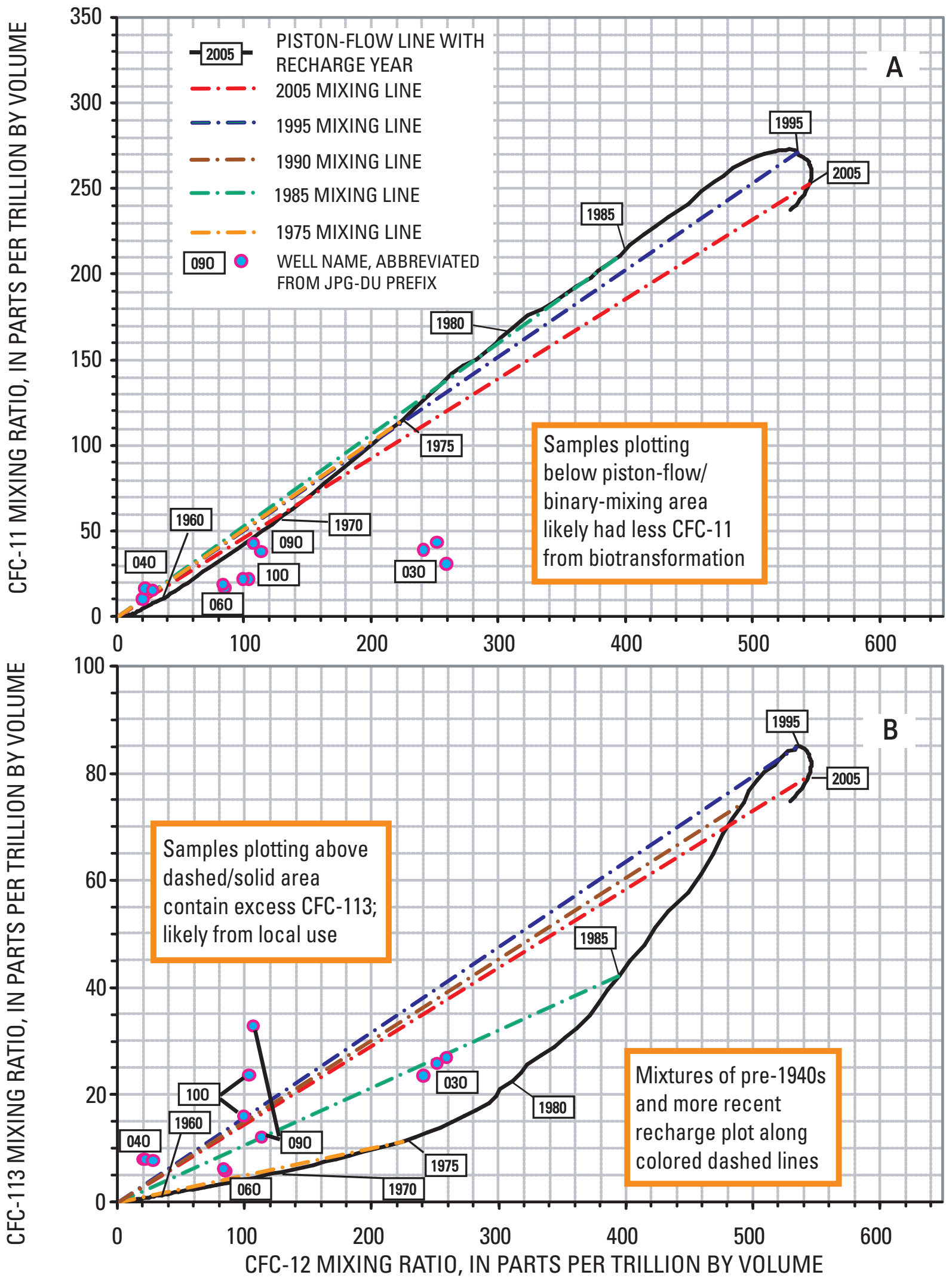

Figure 14. Relation between atmospheric-mixing ratios of chloroflurocarbon compounds in water from wells screened in PreWisconsinan till, Depleted Uranium Impact Area, Jefferson Proving Ground, southeastern Indiana, April 2008. A. CFC-11 and CFC-12; B. CFC-113 and CFC-12. Model lines are included for piston flow and binary mixing of 1975-2005 age water with old (pre-CFC) water. 


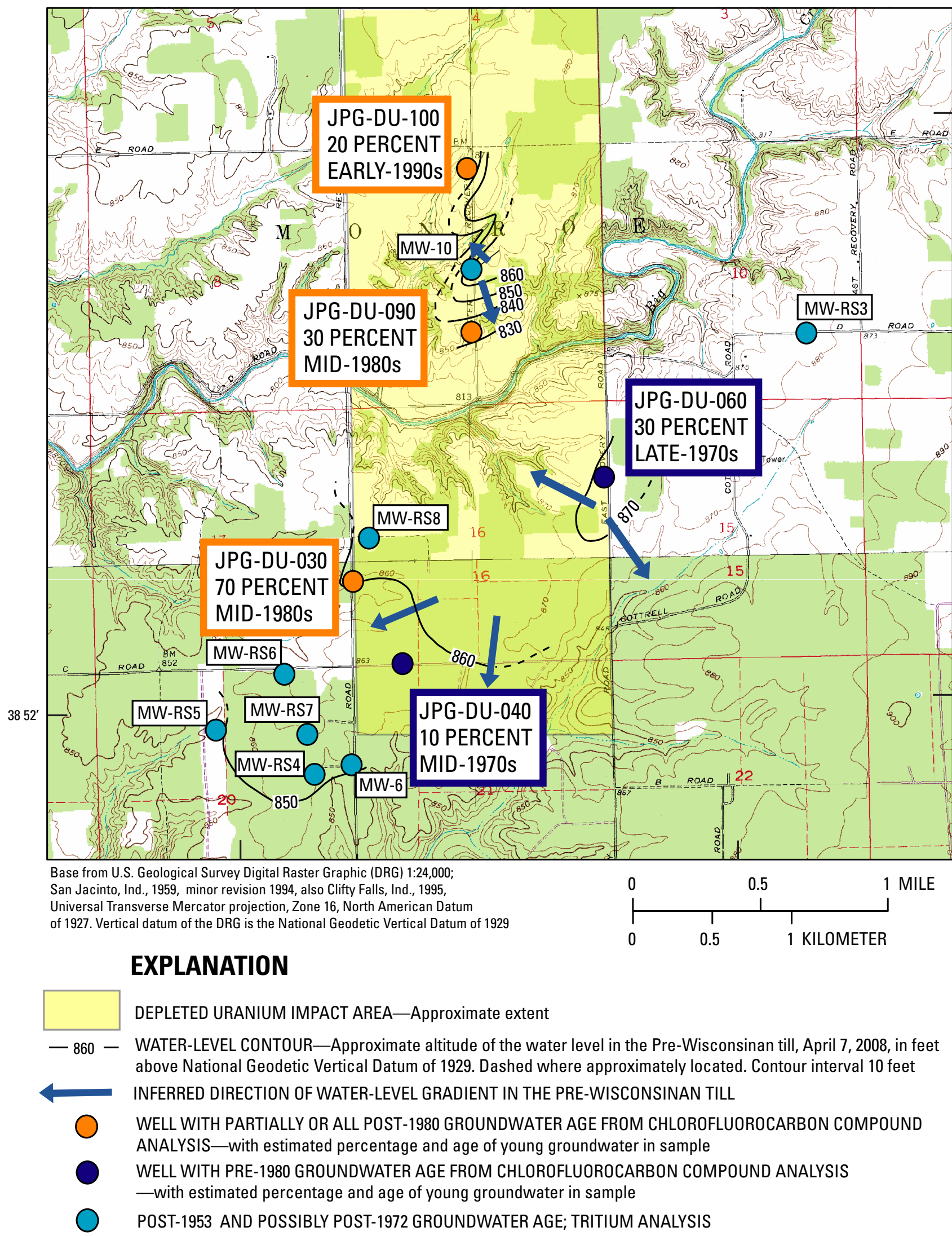

Figure 15. Groundwater-age classifications of water sampled from wells screened in Pre-Wisconsinan till, Depleted Uranium Impact Area, Jefferson Proving Ground, southeastern Indiana, April 2008. 
groundwater quality for effects related to DU-penetrator testing.

Atmospheric-mixing ratios of $\mathrm{CFC}-11$ and $\mathrm{CFC}-12$ in water from two of three sample vials collected from well JPG-DU-04O were best represented as a binary mixture of about 90 percent pre- 1940 water and about 10 percent recent recharge from the mid-1970s (figs. 14 and 15; table 13). The CFC-based age estimate for well JPG-DU-04O was consistent with a tritium-based age estimate for the sample from that well (table 13). These data indicate that groundwater samples from well JPG-DU-04O in April 2008 produced groundwater composed of recharge that predates 1984 and were not of a suitable age to monitor water quality for effects related to DU-penetrator testing.

Atmospheric-mixing ratios of CFC-113 and CFC-12 in water from two other wells from the Pre-Wisconsinan till (JPG-DU-09O and JPG-DU-10O), when interpreted with tritium data, indicated that their composition could be derived partially from post-1980s recharge to groundwater (figs. 14 and 15; table 13). A sample from well JPG-DU-09O (sample vial 2; table 12) and a sequential replicate from well JPGDU-10O (sample vial 5; table 12) with the smallest CFC-113 atmospheric-mixing ratios plotted near binary-mixing curves of about 1985 and 1990 recharge, respectively, with pre1940 recharge (fig. 14). Hypothetical mixtures of pre-1940s recharge with (a) about 30 percent of 1985 recharge to water from well JPG-DU-09O or (b) about 20 percent of 1991 recharge to water from well JPG-DU-10O, respectively, could explain the CFC-113 and CFC-12 atmospheric-mixing ratios and the concentration of tritium in these samples (fig. 15; table 13). The CFC-age dates indicate that wells JPG-DU-09O and JPG-DU-10O produce groundwater that includes recharge from the time of DU-penetrator testing at JPG; the wells are capable of producing water with groundwater-quality effects dating from that time.

One sample vial each from wells JPG-DU-09O and JPG-DU-10O had atmospheric-mixing ratios of CFC-113 that indicated contamination of those samples by CFC-113 from an atmospheric or other source (fig. 14; table 12). A sequentially collected replicate from well JPG-DU-09O (sample vial 3) and the initial sample from well JPG-DU-10O (sample vial 4) had CFC-113 atmospheric-mixing ratios that were from about 50 to 170 percent greater than their sequential replicate, respectively (table 12). These data indicate the potential for CFC-113 to have been used locally and introduced into recharge; CFC113 has had a wide variety of uses, including as an aerosol propellant; as a cleaning agent for electrical and electronic components; and in the production of foam for plastics, packaging, and insulation (Merck and Co., 1989). The agreement of other results from these wells with tritium-based age dates indicate that these specific sample vials represented isolated sample contamination. These results also indicate the need for caution when interpreting CFC-based age dates without corroboration from tritium or other age-dating methods.

The sensitivity of CFC-based age dates to changes in recharge altitude and recharge temperature was evaluated for a sample from well JPG-DU-03O (sample bottle 1); this well was screened in the Pre-Wisconsinan till and had a CFC-based age date which was a mixture that included some recharge from the 1980s (table 14). Sensitivity of age dates was assessed by (1) increasing or decreasing the recharge altitude by $20 \mathrm{ft}$ while holding recharge temperature constant and (2) increasing the recharge temperature by $5^{\circ} \mathrm{C}$ while holding recharge altitude constant. These changes represent possible variability of these properties based on local temperature and land-surface topography.

Increasing the recharge temperature by $5^{\circ} \mathrm{C}$ resulted in a 3 -year decrease in the piston-flow-based groundwater age; the same decrease in recharge temperature increased the pistonflow-based groundwater age by 4 years (table 14). The difference between the two adjustments arises from rounding of the age-date year to an even number. Increasing the recharge temperature by $5^{\circ} \mathrm{C}$ resulted in a 1-year decrease in the age and a 15-percent decrease in the fraction of young recharge in a binary mixture. Decreasing the recharge temperature by $5^{\circ} \mathrm{C}$ resulted in a 1-year increase in the age and an 11-percent increase in the fraction of young recharge in a binary mixture.

An increase or decrease in recharge altitude by $20 \mathrm{ft}$ had no effect on the computed piston-flow age date or the age and fraction of young groundwater in a binary mixture (table 14). These sensitivities to changes in recharge temperature and recharge altitude are consistent with those reported by Plummer and Busenberg (2000, p. 24 and 25). Plummer and Busenberg (2000) specified that a recharge temperature uncertainty of $\pm 2^{\circ} \mathrm{C}$ leads to uncertainty in apparent CFC ages of 1 year or less for water recharged prior to the mid-1970s but larger uncertainties for groundwater recharged after 1990 because the rate of increase in CFC-11, CFC-12, and CFC-113 in the atmosphere slows after 1990.

\section{Shallow Carbonate Unit Groundwater-Age Dates}

Atmospheric-mixing ratios of CFC-11 and CFC-12 and tritium data in water from two wells in the shallow carbonate unit (JPG-DU-01I and JPG-DU-03I) indicated that their composition could be derived partially from mixtures of modern, post-2000 age recharge with pre-1940s age recharge (figs. 16 and 17). The fractions of younger recharge computed for water from these wells using CFC-11/CFC-12 atmospheric ratios were about 10 percent of water sampled from well JPG-DU01I and about 80 percent of water sampled from well JPGDU-03I (table 13). The ages of these CFC-based mixtures in water from wells JPG-DU-01I and JPG-DU-03I were consistent with hypothetical tritium-based mixtures for samples from those wells (table 13). The CFC-based age dates indicate that portions of water sampled from wells JPG-DU-01I and JPG-DU-03I originated as post-1984 modern recharge; these wells therefore could be expected to produce groundwater with some water quality in the sample that dates from after the onset of DU-projectile testing.

Water from well JPG-DU-02I had a CFC-based age date that was best described by a piston-flow (no mixing) based 

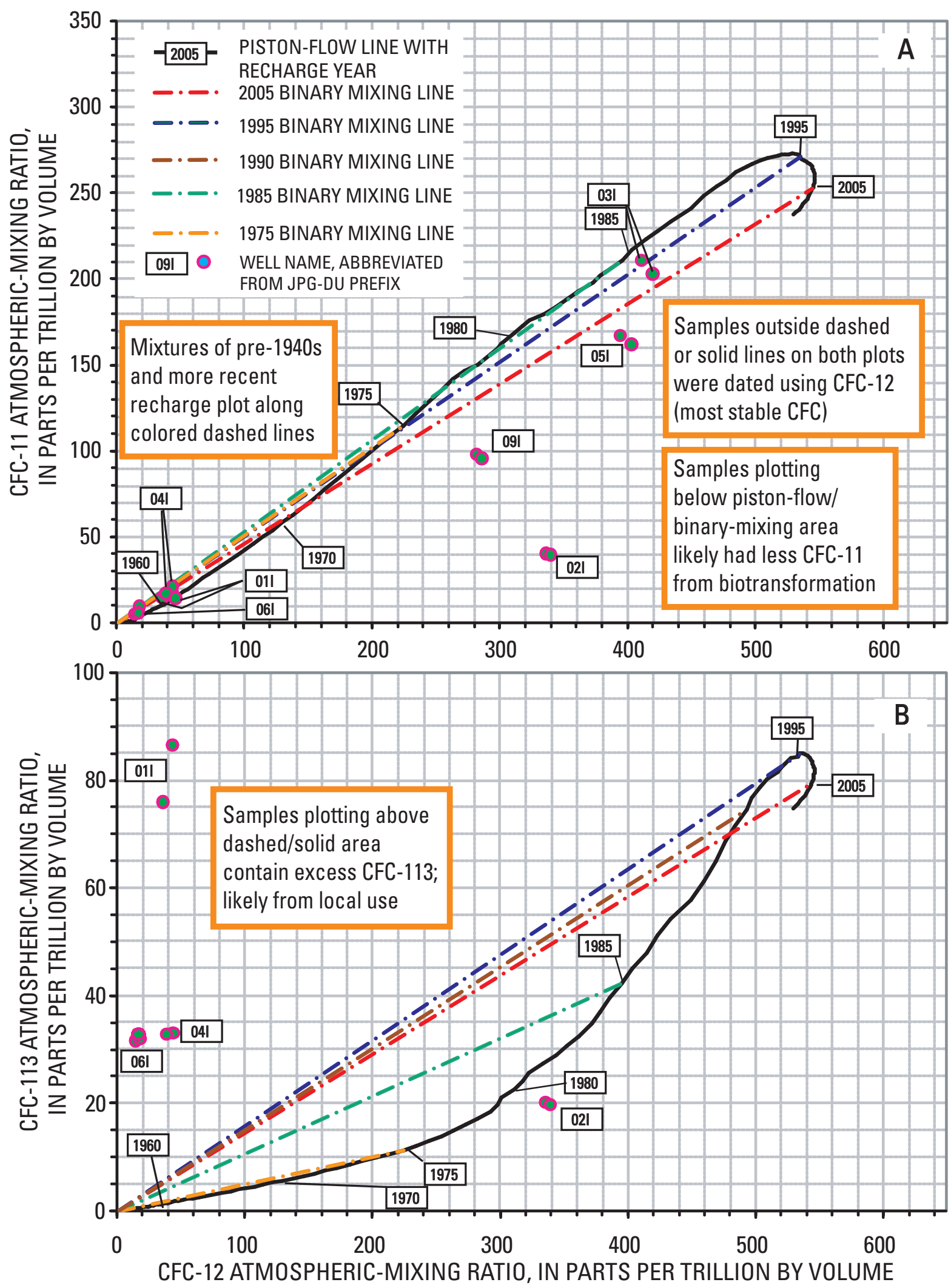

Figure 16. Relation between atmospheric-mixing ratios of chloroflurocarbon compounds in groundwater samples from the shallow carbonate unit in and near the Depleted Uranium Impact Area, Jefferson Proving Ground, southeastern Indiana, April 2008. A. CFC-11 and CFC-12; B. CFC-113 and CFC-12. Model lines are included for piston flow and binary mixing of 1975-2005 age water with old (preCFC) water. 


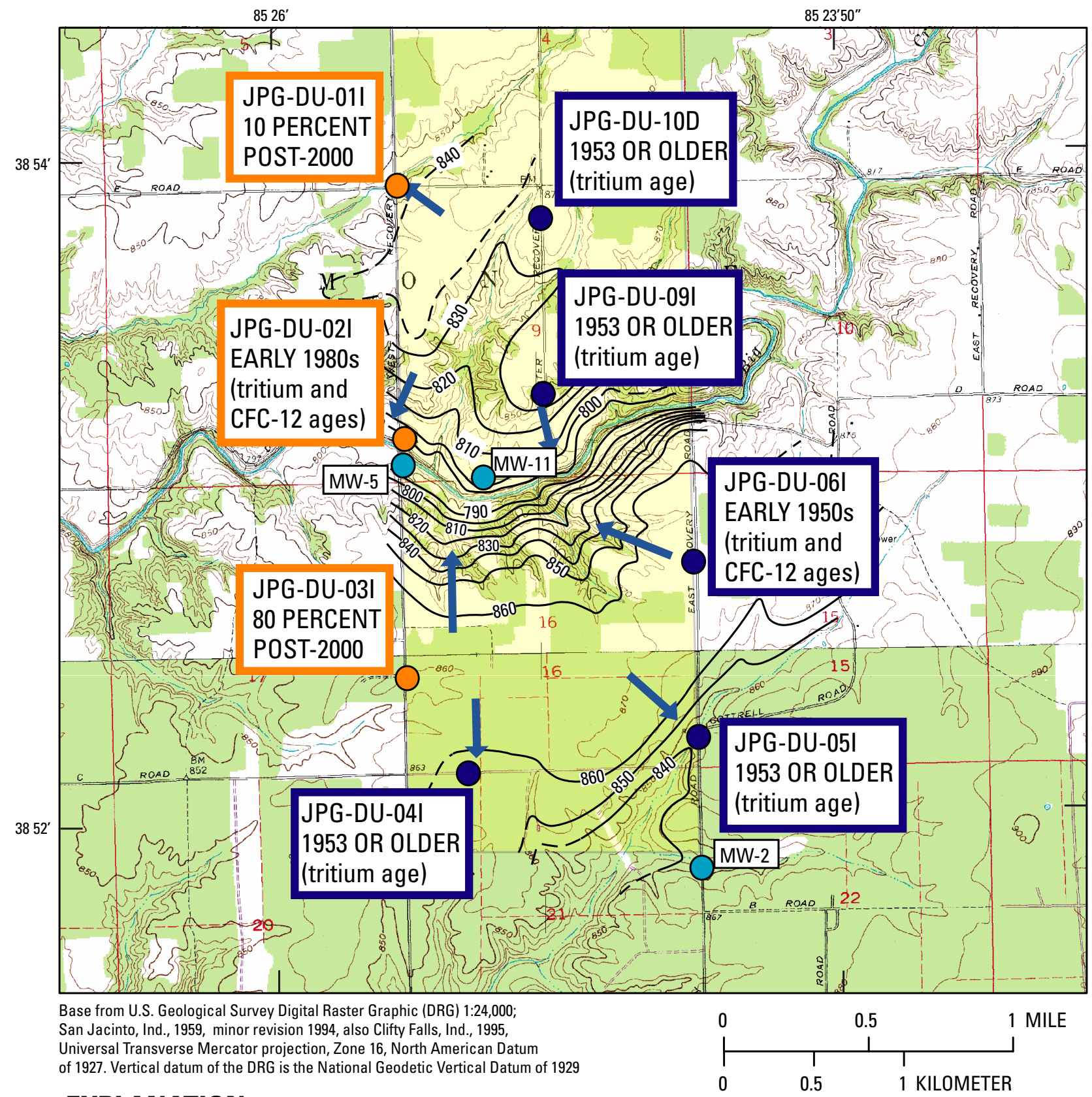

\section{EXPLANATION}

DEPLETED URANIUM IMPACT AREA—Approximate extent

- 830- WATER-LEVEL CONTOUR-Approximate altitude of the water level in the shallow carbonate unit, April 7, 2008, in feet above National Geodetic Vertical Datum of 1929. Dashed where approximately located. Contour interval 10 feet.

INFERRED DIRECTION OF WATER-LEVEL GRADIENT--Direction of groundwater flow may differ because of irregular distribution of interconnected porosity in the shallow carbonate unit

WELL WITH PARTIALLY OR ALL POST-1980 GROUNDWATER AGE FROM CHLOROFLUOROCARBON COMPOUND ANALYSIS — with estimated percentage and age of young groundwater in sample

WELL WITH PRE-1980 GROUNDWATER AGE FROM CHLOROFLUOROCARBON COMPOUND OR TRITIUM ANALYSIS - with estimated percentage and age of young groundwater in sample POST-1953 AND POSSIBLY POST-1972 GROUNDWATER AGE; TRITIUM ANALYSIS

Figure 17. Groundwater-age classifications of water sampled from wells screened in the shallow carbonate unit in and near the Depleted Uranium Impact Area, Jefferson Proving Ground, southeastern Indiana, April 2008. 
Table 14. Sensitivity of CFC-based age dates to changes in recharge temperature and altitude computed for a sample from well JPG-DU-030, Jefferson Proving Ground, southeastern Indiana, April 2008.

[The most reliable groundwater-age dates are in bold type; mm/dd/yy, month/day/year; ${ }^{\circ} \mathrm{C}$, degrees Celsius; ft-VD, altitude in feet above North American Vertical Datum of 1988; CFC-11, trichlorofluoromethane; CFC-12, dichlorodifluoromethane; CFC-113, trichlorotrifluoromethane; pptv, part per trillion by volume; --, not computed]

\begin{tabular}{|c|c|c|c|c|c|c|c|c|c|c|c|c|c|c|c|}
\hline \multirow[t]{2}{*}{ Well name } & \multirow{2}{*}{$\begin{array}{c}\text { Date } \\
\text { sampled } \\
(\mathrm{mm} / \mathrm{dd} / \mathrm{yy})\end{array}$} & \multirow{2}{*}{$\begin{array}{l}\text { Type of sensitivity } \\
\text { adjustment }\end{array}$} & \multirow{2}{*}{$\begin{array}{c}\text { Esti- } \\
\text { mated } \\
\text { recharge } \\
\text { temper- } \\
\text { ature } \\
\left({ }^{\circ} \mathrm{C}\right)\end{array}$} & \multirow{2}{*}{$\begin{array}{c}\text { Esti- } \\
\text { mated } \\
\text { recharge } \\
\text { altitude } \\
\text { (ft-VD) }\end{array}$} & \multirow{2}{*}{$\begin{array}{c}\text { Sam- } \\
\text { ple } \\
\text { bottle }\end{array}$} & \multicolumn{3}{|c|}{$\begin{array}{l}\text { Calculated atmo- } \\
\text { spheric mixing ratio }\end{array}$} & \multicolumn{3}{|c|}{$\begin{array}{l}\text { Groundwater-age } \\
\text { dates, no mixing } \\
\text { (piston flow) } \\
\text { assumed }\end{array}$} & \multirow{2}{*}{$\begin{array}{c}\text { Difference } \\
\text { in median } \\
\text { ground- } \\
\text { water } \\
\text { age since } \\
\text { recharge, } \\
\text { no mixing } \\
\text { assumed } \\
\text { (years) }\end{array}$} & \multirow{2}{*}{$\begin{array}{c}\text { CFC-12/ } \\
\text { CFC-113 } \\
\text { atmos- } \\
\text { pheric } \\
\text { mixing } \\
\text { ratio } \\
\text { (pptv/ } \\
\text { pptv) }\end{array}$} & \multirow{2}{*}{$\begin{array}{c}\text { Differ- } \\
\text { ence in } \\
\text { estimated } \\
\text { CFC-based } \\
\text { age of } \\
\text { young } \\
\text { recharge } \\
\text { in binary } \\
\text { mixture }\end{array}$} & \multirow{2}{*}{$\begin{array}{c}\text { CFC-based } \\
\text { estimated } \\
\text { fraction } \\
\text { of young } \\
\text { recharge } \\
\text { in mixture }\end{array}$} \\
\hline & & & & & & $\begin{array}{l}\text { CFC-11 } \\
\text { (pptv) }\end{array}$ & $\begin{array}{c}\text { CFC-12 } \\
\text { (pptv) }\end{array}$ & $\begin{array}{c}\text { CFC- } \\
113 \\
\text { (pptv) }\end{array}$ & $\begin{array}{c}\text { CFC- } \\
11\end{array}$ & $\begin{array}{c}\text { CFC- } \\
12\end{array}$ & $\begin{array}{c}\text { CFC- } \\
113\end{array}$ & & & & \\
\hline \multirow{3}{*}{ JPG-DU-03O } & & $\begin{array}{l}\text { Decrease tempera- } \\
\text { ture by } 5^{\circ} \mathrm{C}\end{array}$ & 2.2 & 860 & 1 & 28.4 & 183.9 & 16.9 & 1965 & 1973 & 1978 & -3 & .92 & $-1(1983)$ & .52 \\
\hline & & $\begin{array}{l}\text { Increase tempera- } \\
\text { ture by } 5^{\circ} \mathrm{C}\end{array}$ & 12.2 & 860 & 1 & 50.7 & 302.3 & 31.1 & 1969 & 1980 & 1983 & +4 & .103 & +1(1985) & .78 \\
\hline & & $\begin{array}{l}\text { Increase recharge } \\
\text { altitude by } \\
20 \text { feet }\end{array}$ & 7.2 & 880 & 1 & 38.5 & 239.1 & 23.3 & 1967 & 1976 & 1980 & 0 & .097 & 0 (1984) & .67 \\
\hline
\end{tabular}

model of recharge and groundwater flow in the shallow carbonate unit (table 13). A piston-flow based estimate indicated that recharge to well JPG-DU-02I dated from about 1981, or close to the period of DU-projectile testing (table 12). The validity of largely unmixed flow contributing recharge to well JPG-DU-02I also was corroborated by the similarity of the concentration of tritium in the April 2008 water sample, $5.1 \pm 0.6 \mathrm{TU}$, and the decay-corrected concentration of tritium in 1981 precipitation, $6.8 \mathrm{TU}$ (fig. 14; table 13). The CFC- and tritium-age dates indicate that well JPG-DU-02I produces groundwater of a suitable age to monitor water quality for effects related to DU-penetrator testing.

A karst (fractured-and-solution-enhanced) flow system in the shallow carbonate unit also may occur beneath areas mantled by Pre-Wisconsinan till. Piston- or unmixed-flow models of the CFC-12 atmospheric-mixing ratio and concentration of tritium in water sampled from well JPG-DU-06I both yield age dates from the early 1950s. These data indicate that the age of groundwater produced from well JPG-DU-06I was submodern and was not of a suitable age to monitor water quality for changes related to DU-penetrator testing. Piston flow through a network of heterogeneous and discontinuous fractures and solution openings would make for longer, more tortuous flow paths through the shallow carbonate unit and thereby increase the age of groundwater as compared with more direct flow paths.
Four wells, JPG-DU-04I, JPG-DU-05I, JPG-DU-09I, and JPG-DU-10D, that produce groundwater from the shallow carbonate unit had "discordant" age dates; their CFC-12based piston-flow age dates were substantially younger than their corresponding tritium-based age dates (table 13). The small concentrations of tritium in these samples ( 0.1 to 0.5 TU) indicate that nearly all or a substantial percentage of the samples originate as submodern (1953 or older) recharge. The modern CFC-12-based age dates from JPG-DU-04I, JPG-DU05I, JPG-DU-09I, and JPG-DU-10D, however, indicate an unknown source of CFC-12 in the sample.

Plausible explanations for the coincidence of submodern tritium-based age dates and modern CFC-based age dates of water from wells JPG-DU-04I, JPG-DU-05I, JPG-DU09I, and JPG-DU-10D all indicate that tritium is the reliable indicator of age dates of water sampled from these wells. For example, mixing of modern recharge with elevated concentrations of CFCs with submodern recharge has been ruled out as a cause; it also would increase concentrations of tritium above submodern concentrations in the resulting mixed groundwater. Explanations of coincident modern CFC-12 and submodern tritium-age dates in samples from these four wells involve addition of gaseous CFC to the sample, either during its flow in groundwater, by gas entrainment in groundwater during well development, or by leakage into the samples between collection and analysis. Contamination by CFC leakage into the sample vial between collection and analysis is unlikely 
because of the reproducibility of the CFC-12 and CFC-11 analytical results from groundwater samples and their sequential replicates from these four wells (table 15, at end of report).

It is more likely that the concentrations of CFCs and age dates of samples from wells JPG-DU-04I, JPG-DU-05I, JPGDU-09I, and JPG-DU-10D were reset by entrainment of modern CFC into groundwater during well development. In this hypothesis, atmospheric gases with modern concentrations of CFCs are introduced to groundwater during well development. If water levels were lowered below the top of the well screen during the withdrawal of groundwater, atmospheric gases, including modern concentrations of CFCs could enter the formation and dissolve into groundwater (Plummer and others, 2000). Atmospheric concentrations of vadose gases also can be introduced into unsaturated, fractured, or dissolutionmodified rock by barometric pressure changes and exposure to otherwise submodern-age groundwater (Plummer and others, 2000). Tritium results indicate that water samples from these four wells had submodern age dates that are too old to monitor groundwater quality for effects from DU-penetrator testing.

\section{Deep Carbonate Unit Groundwater-Age Dates}

The CFC-12 piston-flow-based estimate of recharge age for the April 2008 water sample from well JPG-DU-09D indicated a mid-1960s age of recharge (table 12). This recharge age, however, is considerably younger than the tritium-based age estimates for samples from the same well that indicates submodern (1953 or older) recharge. Although the CFC12 and tritium-recharge estimates are discordant, both age estimates predate the testing of DU penetrators by 20 or more years. The tritium-based groundwater-age date is the most reliable determination for this well, according to the explanations for discordant ages previously offered in this report. In addition, the slow recovery of water levels in most wells in the deep carbonate unit is consistent with slow rates of groundwater flow and very old groundwater ages in that unit.

The CFC-based and tritium-based age dates of water samples from well JPG-DU-06D are strongly suspect as to whether they represent conditions in the deep carbonate unit. The CFC-12 based recharge age estimate for the sequential replicate sample (sample vial 5) of groundwater from JPGDU-06D was modern (early 2000s) but an age estimate could not be computed for the water sample (sample vial 4) because of apparent contamination with respect to CFC-12 (table 12). The validity of the CFC-12 age estimate from the sequential replicate sample is indicated by the similarity of the concentration of tritium in the associated water sample to the decaycorrected average annual concentration of tritium in 2001 precipitation - the last year of the data record used by this study (table 13). These data indicate that water sampled from well JPG-DU-06D is younger than the water samples from adjacent well JPG-DU-06O in the Pre-Wisconsinan till and is considerably younger than the sample from adjacent well JPGDU-06I in the shallow carbonate unit. Given the greater depth of well JPG-DU-06D (98 ft below land surface datum; table 2) relative to neighboring shallow wells and the overall low permeability of the deep carbonate unit presumed from very low yield during well development (Joseph Skibinski, written commun., Science Applications International Corporation, 2010), it is unlikely for modern age water to have naturally reached the screened interval of this well. Incomplete development prior to sampling or leakage of modern water to the well screen along the well casing during development and sampling also could explain the sampling of modern recharge in water from well JPG-DU-06D; data collected during this study are not sufficient to resolve which explanation is correct.

\section{Vulnerability of Groundwater to Contamination Relative to the Hydrogeologic Framework}

Groundwater-age dates from wells in the PreWisconsinan till are consistent with a conceptual-flow model of vertical infiltration of younger recharge that "mixes" with older recharge from less permeable or less interconnected units within the till. Water sampled from the Pre-Wisconsinan till at five JPG-DU series wells represented a mixture of old, pre-1940s recharge that predates JPG operation and young recharge dating from just before DU-projectile testing (JPGDU-04O and JPG-DU-06O) or from after testing began (JPG-DU-03O, JPG-DU-09O, and JPG-DU-10O) (table 13). The concentrations of chemical constituents that are potential tracers of post-1984 recharge also would be diluted by this mixing; post-1984 recharge has not completely replaced pre-CFC (pre-1940s) groundwater where sampled from the till. In addition, tritium-based groundwater ages from $11 \mathrm{MW}$ and MW-RS series wells that produce water from the PreWisconsinan till ranged from mixtures of submodern (1953 and older) and modern (post-1953) groundwater to substantially modern (post-1953 and possibly post-1972) groundwater. These data also indicate that infiltration of younger recharge is an important process of groundwater flow in the Pre-Wisconsinan till in and near the DU Impact Area.

Wells MW-6, MW-RS4, MW-RS5, MW-RS6, and MW-RS7 are outside of and downgradient from the DU Impact Area (fig. 15). These wells had tritium-based groundwater ages that were substantially modern (post-1953 and possibly post-1972). These ages and flow directions indicate that these wells, and well JPG-DU-03O, may be well positioned to monitor for groundwater-quality effects of DU-projectile testing.

Groundwater-age dates indicate that the shallow carbonate unit adjacent to Big Creek is largely a fairly transmissive but heterogeneous fractured-and-solution-enhanced karst flow system that may be recharged in part from areas with smaller thicknesses of overlying till. Well JPG-DU-02I had CFC- and tritium-based age dates that were best explained by a pistonflow model (table 13). The likely recharge area for JPG-DU02I included an area of the shallow carbonate unit with the thinnest layer amount of overlying till or soil overburden, as indicated by the shallow depth to bedrock (table 2). Recharge to well JPG-DU-02I dated from the early to mid-1980s 
indicates that the source of flow to the well at the time of sampling was from upgradient and upwatershed parts of the shallow carbonate unit. Recent water from bank storage during higher flows in Big Creek, or from vertical recharge into the aquifer adjacent to the well where the till is thin or absent, was not identified in the age date from well JPG-DU-02I (table 13). Wells MW-5 and MW-11 are nearby to JPG-DU-02I and in similar settings along Big Creek, have similar concentrations of tritium and age dates (table 11), and likely have similar recharge sources. The contribution of unmixed recharge to wells JPG-DU-02I, MW-5, and MW-11 through a locally, more conduit-dominated karst flow system is indicated by cave development in the shallow carbonate unit immediately adjacent to Big Creek (Sheldon, 1997).

The thickness or permeability of Pre-Wisconsinan till is an important factor in how quickly modern recharge reaches the shallow carbonate unit. Two wells in the shallow carbonate unit that locally have thin soil or till cover (JPG-DU-01I; table 2) or that are closer to surface expressions of fracturing or linear karst features in the subsurface (JPG-DU-03I) had age dates that were best explained as mixtures of young recharge and some old, pre-1940 recharge. The large part of post-2000 age recharge contributing to water produced from well JPG-DU-03I indicates the likely proximity of this well to recharge features. Well JPG-DU-01I locally has a thin cover of till or soil overburden (20 ft; table 2 ) but also is downgradient from parts of the shallow carbonate unit that presumably receive less recent recharge because of thicker overlying till deposits (fig. 11). This combination of hydrogeologic framework near the well corroborates the interpretation of the groundwater age of water from well JPG-DU-01I as a mixture of a small part (about 10 percent) of post-2000 age local recharge with about 90 percent of old, pre-CFC, pre-1940 recharge from upwatershed areas with thicker till deposits over the shallow carbonate unit.

Groundwater flow directions, as inferred from water-level contours, in combination with groundwater-age dates also assist in identifying which wells in the shallow carbonate unit may be susceptible to water-quality effects from activities in the DU Impact Area. Wells JPG-DU-01I, JPG-DU-02I, and JPG-DU-03I are located within or downgradient from the DU Impact Area based on the inferred groundwater flow directions in the shallow carbonate unit (fig. 11). These wells also produced some part of their groundwater from recharge that dated from about 1980 or later. Two MW-series wells in this area have similar concentrations of tritium to that from well JPG-DU-02I; their age dates represent mixtures of submodern and modern water (MW-5) or substantially modern water (MW-11). MW-5 and MW-11 are downgradient with respect to groundwater levels from upland parts of the Big Creek watershed in the DU Impact Area (fig. 11). Regional gradients likely are overall expressions of groundwater-flow directions although flow directions within the shallow carbonate unit would reflect the complex interconnections of open fractures and dissolution-modified features within the unit. The complexity of local groundwater-flow directions within similar formations to the shallow carbonate unit was previously described for wells south of the firing line (Wilson and others, 2001). These data indicate that wells JPG-DU-01I, JPG-DU-02I, MW-5, MW-11, and possibly JPG-DU-03I potentially are the most useful sampling points at which to evaluate the presence of groundwater quality affected by DU-projectile testing.

Wells with older age dates that predate the penetrator testing can also be used to assess background water chemistry conditions in each water bearing unit. The submodern ages of groundwater from wells JPG-DU-04I, JPG-DU-05I, JPG-DU-06I, JPG-DU-09I, and JPG-DU-10D in the shallow carbonate unit indicate that their sources of recharge are from upgradient areas capped by thicker or less permeable deposits of Pre-Wisconsinan till; water from these wells was composed of recharge that predated DU-projectile testing. These five wells each produced adequate amounts of water for sampling; they were installed on or near surface indications of fractures and (or) subsurface indications of permeable features in the bedrock. The distribution of groundwater-age dates (fig. 17) indicates that the easternmost (upgradient) and southernmost parts of the shallow carbonate unit under the DU Impact Area may derive recharge from slower flow paths through karst features that are more isolated from land surface as compared with wells along the western DU Impact Area boundary and along Big Creek. Age dating indicates that the age of recharge sampled from these five wells predates the DU testing by about 30 or more years; therefore, water quality from these wells is not likely to reflect effects from DU-projectile testing or residual-corrosion products for years.

Data collected during this investigation are not sufficient to resolve whether the hydrogeologic framework or well-construction factors provide a better explanation for the modern water sampled from the deep carbonate unit at well JPG-DU-06D. Water sampled from the deep carbonate unit at well JPG-DU-06D had CFC- and tritium-based age dates that indicated modern groundwater; much younger than water produced from adjacent well JPG-DU-06I in the shallow carbonate unit (table 13). The young age of water sampled from well JPG-DU-06D could represent a very direct source of modern recharge to the well. Water produced by well JPG-DU-06D must recharge to a $40 \mathrm{ft}$ greater depth into the carbonate bedrock, and conceivably along a longer flow path, than water produced by well JPG-DU-06I (table 2). Plausible human-affected explanations for the detection of modern water from JPG-DU-06D include the possibility that water sampled from this well could be (a) from modern water used for well construction or (b) from vertical leakage of recharge along the well bore past the grout seal separating the screened interval from land surface.

\section{Implications and Limitations of the Age-Dating Technique}

The use of multiple constituents to classify groundwater age improved the ability of this analysis to identify 
groundwater samples that potentially contained some fraction of post-1953 recharge. Groundwater samples from several wells had concentrations of tritium that were less than $0.8 \mathrm{TU}$, the common threshold used to distinguish submodern-age, 1953 or older recharge from water that contains some volume of post-1953 recharge (Clark and Fritz, 1997). When CFC data also were used to interpret the age dates for samples from wells JPG-DU-04O, JPG-DU-09O, and JPG-DU-10O, the sample age indicated mixtures containing 20 to 30 percent modern recharge.

The proportions of young and old groundwater in samples that are best described as binary mixtures may vary owing to hydrologic condition; this sampling represents one event in time. The sensitivity analysis of the CFC-based age date for water from well JPG-DU-03O indicates that the relative percentage of modern water in a binary mixture was sensitive to recharge temperature; a difference of $5^{\circ} \mathrm{C}$ in recharge temperature produced about a 10 to 15 percent change in the fraction of modern groundwater contributing to the sample (table 14). The binary mixtures were therefore reported to the nearest 10 percent. Within these limits, however, the explanation of age dates as binary mixtures of modern and submodern water indicate that concentrations of constituents derived from modern activities at land surface also would be affected - either diluted or enriched in the resulting groundwater-by the mixing with older water.

Several limitations of the age dating methods were described in this report in connection with interpretations of groundwater age dates. The effect of the laboratory precision of tritium on groundwater age classifications was evaluated by including the 2-sigma precision of those analyses in the classification. Limitations with CFC-based age classifications reported by this study included possible issues with well construction (such as for JPG-DU-06D), subareal exposure of groundwater and incorporation of CFCs into otherwise submodern age groundwater (such as identified for the sample from JPG-DU-05I), and potential introduction of excess CFC from local atmospheric sources into groundwater. Each of the potential limitations on CFC-based age dates would bias the estimates toward younger ages. The effect of these limitations was identified and in most cases removed from the age-date interpretation by comparing the CFC-based age dates to the tritium-based age classification, tritium being less susceptible to several of the causes of interferences with CFC age dates.

The post-1995 decrease of atmospheric mixing ratios of CFC-11 and CFC-113 (fig. 6) can affect the classification of groundwater age dates involving a mixture with some part of modern, post-1995 recharge using piston flow and binary mixing models. CFC-based groundwater age dates from wells JPG-DU-10O, JPG-DU-01I, and JPG-DU-03I all involved mixtures with post-1990 groundwater (table 13). After 1995, the piston flow curve inverts to a downward slope for both CFC- 11 and CFC-113 relative to CFC- 12 concentrations. The inversion creates the possibility that CFC-based mixtures that involve some part of 1990 to 2005 age groundwater can have two possible initial concentrations of CFC-11 and CFC-113, one from the 1990-1995 rising part of the piston flow curve and one from the 1995-2005 falling part of the curve.

Several strategies were used to interpret which age estimate was appropriate for the young fraction of recharge in these mixtures. In the case of a sample from well JPG-DU-03I, the atmospheric mixing ratios of CFC-11 and CFC-12 plotted in an area of figure 16 whose position could only be explained by binary mixtures of groundwater recharge from about 1995 to 2000 with CFC-free groundwater. In the case of a sample from well JPG-DU-01I, the atmospheric mixing ratios of CFC-11 and CFC-12 in the groundwater sample could be explained by binary mixtures of groundwater recharge from about either 2005 or from about 1965 with CFC-free groundwater (fig. 16). However, the tritium concentration of a hypothetical mixture (14.4 TU) of a 50 percent 1965 -age recharge (28 TU, fig. 5) with 50 percent submodern recharge (0.8 TU) was substantially greater than the tritium concentration of the water sample from that well plus its 2-sigma uncertainty ( 0.6 TU). Therefore, the mixture of 2005 age recharge and CFCfree recharge was deemed the most plausible explanation for the CFC- 11 and CFC-12 concentrations in the samples from well JPG-DU-01I. The atmospheric mixing ratios of CFC-113 and CFC-12 in a sample from well JPG-DU-10O (fig. 14) could be explained by a mixture of groundwater recharge from about either 1992 or 1996 with CFC-free groundwater. The age of recharge contributing to the young part of this mixture could not be distinguished using the tritium technique.

Methods used by this study could not distinguish whether mixtures of submodern and modern groundwater identified with age dating constituents occurred in the formation or in the well itself. Several wells had concentrations of age dating constituents that were best explained as binary mixtures of submodern and modern age groundwater. In-formation mixing could occur along the convergence of flow paths to a well screen. In-well mixing could arise if the well screen intersected geologically separate flowpaths with different groundwater ages. The potential for in-well mixing is generally increased by use of progressively longer well screens.

\section{Summary and Conclusions}

During 1984-94, the U.S. Department of the Army test fired depleted uranium (DU) projectiles ("penetrators") under the authority of a Nuclear Regulatory Commission license into an area of approximately 2,080 acres north of the firing line, known as the DU Impact Area, at Jefferson Proving Ground (JPG) in southeastern Indiana. The Army and its contractor, Science Applications International Corporation (SAIC), began in 2006 an investigation of the hydrologic and hydrogeologic framework of a Pre-Wisconsinan till and underlying shallow and deep carbonate bedrock units in an around the DU Impact Area to understand processes that could affect the fate and transport of possible contaminants. The U.S. Geological Survey, in cooperation with the Army, evaluated the relative age of groundwater in Pre-Wisconsinan till and underlying 
shallow and deep carbonate bedrock units from in and near an area at the JPG that was used during 1984-94 to test fire DU penetrators. Wells with younger age dates from after the onset (1984) of DU penetrator testing and that have a plausible connection to a contaminant source can be used to indicate the presence or absence of contaminants from DU penetrator or DU-related corrosion products in groundwater. Wells with older age dates that predate the penetrator testing can also be used to assess background water chemistry conditions in each water bearing unit.

Samples collected during April 2008 from 15 wells were analyzed for field water-quality parameters, dissolved gases, and the age-dating constituents: tritium and chlorofluorocarbon (CFC) compounds; samples from 14 additional wells were analyzed for tritium only. The hydrogeologic framework was classified as a Pre-Wisconsinan till, an underlying shallow carbonate unit that represents a zone of fractures, paleokarst, and other dissolution-modified features within the upper 40 feet of carbonate bedrock, and a deeper carbonate unit that groups wells that produce from depths that are more than about 40 feet below the bedrock surface. Water-level gradients in the Pre-Wisconsinan till and the shallow carbonate unit were from topographically high parts of the study area toward major streams, Big Creek and Middle Fork Creek, and their tributaries. Regional flow directions in the deep carbonate unit could not be defined. Vertical gradients between the PreWisconsinan till and the shallow carbonate unit were downward at three sites (well pairs JPG-DU-04O and 04I, JPG-DU$06 \mathrm{O}$ and 06I, and JPG-DU-09O and 09I) and upward at two sites (well pairs JPG-DU-03O and 03I, and JPG-DU-10O and 10D). Vertical gradients were strongly downward from the shallow carbonate unit toward the deep carbonate unit at 3 of 4 paired wells where water levels recovered after development; indicating the general lack of flow between the two units. The lack of post development recovery of water levels at 4 other wells in the deep carbonate unit indicate that parts of that unit have no appreciable permeability.

Groundwater level measurements and land-surface altitudes were used to assign a recharge altitude to water from each well for recharge temperature and CFC-based age-dating computations. The recharge altitudes of water from wells screened in Pre-Wisconsinan till were assumed to be similar to the observed groundwater levels from those wells, rounded to the nearest 5 feet; these recharge altitudes ranged from 840 feet above the vertical datum for well JPG-DU-090 to 870 feet above the vertical datum for well JPG-DU-06O. Groundwater recharge to wells that were open to the shallow and deep carbonate units likely occurred upgradient from the well and at higher water-level altitudes than the sampled depth. Recharge altitudes used for dissolved gas and CFC-based groundwaterage computations for water from wells in the shallow carbonate unit ranged from 810 feet above the vertical datum for well JPG-DU-02I to 870 feet above the vertical datum for well JPG-DU-06I.

Analyses of dissolved gas in groundwater were interpreted to estimate the temperature of water at the time it infiltrated below the water table and into groundwater. Estimated average recharge temperatures of groundwater indicate that most recharge to groundwater in the study area occurs during the cooler months of fall, winter, and spring seasons when evapotranspiration typically is smallest. Estimated average recharge temperatures of groundwater ranged from 1.5 degrees Celsius $\left({ }^{\circ} \mathrm{C}\right.$ ) at well JPG-DU-04O to $11.7^{\circ} \mathrm{C}$ at well JPG-DU-3I; the median recharge temperature was $7.1^{\circ} \mathrm{C}$. Most wells had recharge temperatures that were $8.6^{\circ} \mathrm{C}$ or less; these corresponded to the range of monthly average air temperatures at Madison, Indiana, from November to March $\left(-0.7^{\circ} \mathrm{C}\right.$ to $7.4^{\circ} \mathrm{C}$ ), indicating that most recharge occurred during the cooler, non-growing months.

Groundwater-age dates from wells in the Pre-

Wisconsinan till are consistent with a conceptual-flow model of vertical infiltration of younger (typically post-1960 age) recharge that "mixes" with older recharge from less permeable or less interconnected strata within the till. The CFC- and tritium-based age dates of groundwater samples from five wells in the Pre-Wisconsinan till could be explained best as binary mixtures of young, post-CFC and 1953 or older recharge. Part of the mixture of recharge that contributed to water samples from three wells in the Pre-Wisconsinan till, JPG-DU-03O, JPG-DU-09O, and JPG-DU-10O, dated from the early to mid1980s. These age dates indicate the potential for water samples from wells in the Pre-Wisconsinan till to detect water quality modified by activities associated with DU-penetrator testing at JPG. The age-dating information also indicates that concentrations of chemical constituents, which are potential tracers of post-1984 recharge, will be diluted by this mixing; post-1984 recharge had not completely replaced pre-1940s groundwater, where sampled from the till. No wells in the Pre-Wisconsinan till produced entirely submodern recharge, although age dates of groundwater that contributed to mixtures produced from wells JPG-DU-04O and JPG-DU-06O predated 1980.

In addition, water from wells MW-6, MW-10, MW-RS3, MW-RS4, MW-RS5, MW-RS6, and MW-RS7 in the PreWisconsinan till also had tritium-based age dates that indicated the possible presence of post-1972 age recharge. Water from these seven MW and MW-RS series wells also may produce water samples that could indicate water quality modified by activities associated with DU-penetrator testing at JPG. The possibility that the MW and MW-RS series wells could produce groundwater containing recharge from the 1984 and later period affected by DU testing cannot be ruled out solely by use of tritium data; therefore, water quality from the post1984 testing period of DU penetrators could be monitored from these wells.

Groundwater-age dates indicate that the shallow carbonate unit adjacent to Big Creek largely is a fairly transmissive but heterogeneous karst (fractured-and-solution-enhanced) flow system that may be recharged in part from areas with smaller thicknesses of overlying till. The till is thin or absent near Big Creek at wells JPG-DU-02I, MW-5, and MW-11. A CFC- and tritium-based piston-flow based age date of the early 1980s for water produced from well JPG-DU-02I, 
similar concentrations of tritium and tritium-based ages of water produced from well JPG-DU-02I and from nearby wells MW-5 and MW-11, and evidence of cave development along Big Creek together indicate the importance of local, conduitbased, karst flow systems in the shallow carbonate unit near the creek.

Piston flow in the shallow carbonate unit also may occur beneath Pre-Wisconsinan till. CFC- and tritium-based pistonflow models of water sampled from well JPG-DU-06I both yielded age dates of recharge contributing to the well from the early 1950s. The data indicate that groundwater produced from well JPG-DU-06I had recharged more than 30 years before the initial testing of DU penetrators; water quality from the well would not exhibit effects related to DU-penetrator testing or later leaching of residual-corrosion products.

The thickness or permeability of Pre-Wisconsinan till affects the time that modern recharge takes to infiltrate to the shallow carbonate unit. Part or all of the groundwater from wells JPG-DU-01I, JPG-DU-02I, and JPG-DU-03I in the shallow carbonate unit included recharge dating from about 1980 or later. The CFC- and tritium-based age dates indicate that water sampled from wells JPG-DU-01I and JPG-DU-03I was best described as a mixture of post-1984 modern recharge and submodern (1953 or older) recharge.

Four wells in the shallow carbonate unit, JPG-DU-04I, JPG-DU-05I, JPG-DU-09I, and JPG-DU-10D, and well JPGDU-09D in the deep carbonate unit produced groundwater samples with old (submodern, 1953 or older) tritium-based age dates and young (modern, 1960s to 1980s) CFC-based age dates. The disagreement likely arises by the exposure of submodern groundwater, well after recharge and during groundwater flow, to atmospheric concentrations of CFCs. Concentrations of tritium were therefore used to compute age dates for water from these wells; their groundwater-age dates were submodern (1953 or older). Water quality sampled from these four wells should represent background conditions; this groundwater should not exhibit effects related to DU-penetrator testing or later leaching of residual-corrosion products for at least 30 years after this sampling.

The submodern ages of groundwater from wells JPG-DU04I, JPG-DU-05I, JPG-DU-06I, JPG-DU-09I, and JPG-DU$10 \mathrm{D}$ in the shallow carbonate unit indicate that their sources of recharge are from upgradient areas capped by thicker or less permeable deposits of Pre-Wisconsinan till; water from these wells was composed of recharge that predated DU-projectile testing. The distribution of groundwater-age dates (fig. 17) indicates that the easternmost (upgradient) and southernmost parts of the shallow carbonate unit under the DU Impact Area may derive recharge from slower flow paths through karst features that are more isolated from land surface as compared with wells along the western DU Impact Area boundary or along Big Creek. Age dating indicates that the age of recharge sampled from these five wells predates the DU testing by about 30 or more years; therefore, water quality from these wells is not likely to reflect effects from DU-projectile testing or residual-corrosion products for years.
Incomplete removal of water from drilling by development prior to sampling or leakage of modern water to the well screen along the well casing before or during development and sampling also could explain the sampling of recent, post-2000 recharge in water from well JPG-DU-06D. The age date of water sampled from this well could not be reliably determined.

Based on water-level contours and age dates, water quality from several wells in the shallow carbonate unit may partially represent recharge affected by activities in the DU Impact Area. Wells JPG-DU-01I, JPG-DU-02I, and JPGDU-03I are within or downgradient from the DU Impact Area, with respect to water levels, and produce some part of their groundwater from recharge that dated from about 1980 or later. Water from wells MW-5 and MW-11 have similar concentrations of tritium and presumably similar age dates to water from well JPG-DU-02I and are downgradient from parts of the DU Impact Area. Although flow paths to wells JPGDU-01I, JPG-DU-02I, JPG-DU-03I, MW-5, and MW-11 may be complex and not directly along the water-level gradient, their age dates and hydrogeologic information indicate that these five wells potentially are the most useful for sampling the shallow carbonate unit to identify possible water-quality effects from DU-related contaminants in groundwater.

\section{References Cited}

Anderson, C.W., 2005, National field manual for the collection of water-quality data-Turbidity: U.S. Geological Survey Techniques of Water-Resources Investigations, book 9, chap. A6, section 6.7, version 2.1, accessed February 24, 2010, at http://water.usgs.gov/owq/FieldManual/Chapter6/ Section6.7_v2.1.pdf.

Bartolino, J.R., 1997, Chlorofluorocarbon and tritium age determination of ground-water recharge in the Ryan Flat subbasin, Trans-Pecos Texas: U.S. Geological Survey Water-Resources Investigations Report 96-4245, 29 p.

Bradley, P.M., Chapelle, F.H., and Löeffler, F.E., 2008, Anoxic mineralization: Environmental Reality or Experimental Artifact?: Ground Water Monitoring and Remediation, v. 28 , p. $47-49$.

Busenberg, Eurybiades, and Plummer, L.N., 1992, Use of chlorofluorocarbons $\left(\mathrm{CCl}_{3} \mathrm{~F}\right.$ and $\left.\mathrm{CCl}_{2} \mathrm{~F}_{2}\right)$ as hydrologic tracers and age-dating tools-The alluvium and terrace system of central Oklahoma: Water Resources Research, v. 28, no. 9 , p. 2,257-2,283.

Busenberg, Eurybiades, Plummer, L.N., Bartholomay, R.C., and Wayland, J.E., 1998, Chlorofluorocarbons, sulfur hexafluoride, and dissolved permanent gases in ground water from selected sites in and near the Idaho National Engineering and Environmental Laboratory, Idaho, 199491: U.S. Geological Survey Open-File Report 98-274, (DOE/ID-22151), 72 p. 
Busenberg, Eurybiades, Plummer, L.N., Doughten, M.W., Widman, P.K., and Bartholomay, R.C., 2000, Chemical and isotopic composition and gas concentrations of ground water and surface water from selected sites at and near the Idaho National Engineering and Environmental Laboratory, Idaho, 1994-97: U.S. Geological Survey Open-File Report 00-81, 51 p.

Clark, I.D., and Fritz, Peter, 1997, Environmental isotopes in hydrogeology: Boca Raton, Fla., CRC Press/Lewis Publishers, 328 p.

DeBroka, K.M., and Cohen, D.A., 1999, Digital dataset of 14-digit hydrologic units in Indiana: U.S. Geological Survey Fact Sheet FS-143-99, 4 p.

Fleming, A.H., Bonneau, Phillip, Brown, S.E., Grove, Glen, Harper, Denver, Herring, William, Lewis, E.S., Moeller, A.J., Powell, Richard, Reehling, Peter, Rupp, R.F., and Steen, W.J., 1995, Atlas of hydrogeologic terrains and settings of Indiana: Indiana Geological Survey Open-File Report 95-7.

Gossett, J.M., 2010. Sustained aerobic oxidation of vinyl chloride at low oxygen concentrations: Environmental Science and Technology, v. 44, p. 1,405-1,411.

Gray, H.H., 1972, Geologic map of the $1^{\circ} \mathrm{x} 2^{\circ}$ Louisville quadrangle, Indiana, showing bedrock and unconsolidated deposits: Indiana Department of Natural Resources, Geological Survey, Regional Geologic Map No. 6.

Gray, H.H., 2000, Physiographic divisions of Indiana: Bloomington, Ind., Indiana Geological Survey Special Report 61, 15 p., 1 pl.

Greeman, T.K., 1981, Lineaments and fracture traces, Jennings County and Jefferson Proving Ground, Indiana: U.S. Geological Survey Open-File Report 81-1120, 20 p., 1 pl.

Grossblatt, Norman, ed., 2008, Committee on Gulf War and Health-Updated literature review of depleted uranium: Institute of Medicine, accessed July 30, 2009, at http://www. nap.edu/catalog/12183.html.

Grosse, A.V., Johnston, W.M., Wolfgang, R.L., and Libby, W.F., 1951, Tritium in nature: Science, v. 113, p. 1, 2.

Heaton, T.H.E., and Vogel, J.C., 1981, "Excess air" in groundwater: Journal of Hydrology, v. 50, p. 201-216.

Horiba Ltd., 2001, Multi-Parameter Water Quality Monitoring System, U-20XD series-U-22XD Operation manual: Horiba, Ltd., Irvine, Calif., accessed June 10, 2010, at http://www.geotechenv.com/Manuals/Horiba_Manuals/ U-22XD_manual.pdf.

International Atomic Energy Agency, 1981, Statistical treatment of environmental isotope data in precipitation: Vienna, Austria, Technical Report Series Number 206, 255 p.
International Atomic Energy Agency, 2006, Use of chlorofluorocarbons in hydrology-A guidebook: Vienna, Austria, 278 p.

Levine, I.N., 1978, Physical chemistry: New York, McGrawHill, 847 p.

Lindsey, B.D., Berndt, M.P., Katz, B.G., Ardis, A.F., and Skach, K.A., 2009, Factors affecting water quality in selected carbonate aquifers in the United States, 1993-2005: U.S. Geological Survey Scientific Investigations Report 2008-5240, 117 p.

Lindsey, B.D., Phillips, S.W., Donnelly, C.A., Speiran, G.K., Plummer, L.N., Böhlke, J.K., Focazio, M.J., Burton, W.C., and Busenberg, Eurybiades, 2003, Residence times and nitrate transport in ground water discharging to streams in the Chesapeake Bay Watershed: U.S. Geological Survey Water-Resources Investigations Report 03-4035, 201 p.

Lucas, L.L., and Unterweger, M.P., 2000, Comprehensive review and critical evaluation of the half-life of tritium: Journal of Research of the National Institute of Standards and Technology, v. 105, no. 4, p. 541-549.

Merck and Co., 1989, The Merck index-2140—Chlorofluorocarbons: Rahway, N.J., 1,606 p., plus appendixes.

Michel, R.L., 2004, Tritium hydrology of the Mississippi River basin: Hydrological Processes, v. 18, p. 1,255-1,269.

Midwestern Regional Climate Center, 2009a, Historical climate data-Temperature summary, station 125237 MADISON, IN, 1971-2000 NCDC normals: accessed January 28, 2009, at http://mcc.sws.uiuc.edu/climate_ midwest/historical/temp/in/125237_tsum.html.

Midwestern Regional Climate Center, 2009b, Historical climate data-Precipitation summary, station 125237 MADISON, IN, 1971-2000 NCDC normals: accessed January 28, 2009, at http://mcc.sws.uiuc.edu/climate_ midwest/historical/precip/in/125237_psum.html.

National Weather Service, 2008, Weather conditions for BIGI3 - Big Oaks - Real-time observation monitor and analysis network: accessed February 19, 2010, at http://raws.wrh.noaa.gov/cgi-bin/roman/meso_base. cgi?stn=BIGI3.

Olsen, L.D., and Spencer, T.A., 2000, Assessment of volatile organic compounds in surface water at West Branch Canal Creek, Aberdeen Proving Ground, Maryland, 1999: U.S. Geological Survey Open-File Report 00-203, 15 p.

Plummer, L.N., Böhlke, J.K., and Busenberg, Eurybiades, 2003, Approaches for ground-water dating, in Lindsey, B.D., Phillips, S.W., Donnelly, C.A., Speiran, G.K., Plummer, L.N., Böhlke, J.K., Focazio, M.J., Burton, W.C., and Busenberg, Eurybiades, 2003, Residence times and nitrate transport in ground water discharging to streams in 
the Chesapeake Bay watershed: U.S. Geological Survey Water-Resources Investigations Report 03-4035, p. 12-24.

Plummer, L.N., and Busenberg, Eurybiades, 2000, Chlorofluorocarbons, in Cook, P.G., and Herczeg, A.L., eds., Environmental tracers in subsurface hydrology: Norwell, Mass., Kluwer Academic Publishers, p. 441-478.

Plummer, L.N., Rupert, M.G., Busenberg, Eurybiades, and Schlosser, Peter, 2000, Age of irrigation water in ground water from the Eastern Snake River Plain aquifer, southcentral Idaho: Ground Water, v. 38, no. 2, p. 264-283.

Radtke, D.B., Davis, J.V., and Wilde, F.D., 2005, Specific electrical conductance (version 1.2): U.S. Geological Survey Techniques of Water-Resources Investigations, book 9, chap. A6, section 6.3, August, accessed December 28, 2009, at http://water.usgs.gov/owq/FieldManual/ Chapter6/Ch6_contents.html.

Rowe, G.L., Dunkle-Shapiro, Stephanie, and Schlosser, Peter, 1999, Use of environmental tracers to evaluate ground-water age and water-quality trends in a buried-valley aquifer, Dayton area, southwestern Ohio: U.S. Geological Survey Water-Resources Investigations Report 99-4113, 81 p.

Scheeringa, Ken, 2002, Climate of Indiana-IClimate.org: Indiana State Climate Office at Purdue University, accessed March 16, 2010, at http://climate.agry.purdue.edu/climate/ narrative.asp.

Schneider, A.F., 1966, Physiography, in Lindsay, A.A., ed., Natural features of Indiana: Indiana Academy of Science and Indiana State Library, p. 40-56.

Schwarzenbach, R.P., Gschwend, P.M., and Imboden, D.M., 1993, Environmental organic chemistry: New York, Wiley, $681 \mathrm{p}$.

Science Applications International Corporation, 2007a, Well location selection report-Depleted Uranium Impact Area site characterization-Soil verification, surface water gauge installation, fracture trace analysis, and electrical imaging, Jefferson Proving Ground, Madison, Indiana: Submitted to the U.S. Department of Army Installation Support Management Activity, Aberdeen Proving Ground, Md., and U.S. Army Corps of Engineers, Louisville District, 245 p.

Science Applications International Corporation, 2007b, Draft Field Sampling Plan addendum 4-Depleted Uranium Impact Area site characterization-Site characterization-Monitoring well drilling and installation, Jefferson Proving Ground, Madison, Indiana: Submitted to the U.S. Department of Army Installation Support Management Activity, Aberdeen Proving Ground, Md., and U.S. Army Corps of Engineers, Louisville District, 99 p.

Science Applications International Corporation, 2008, Draft Field Sampling Plan addendum 5-Depleted Uranium
Impact Area site characterization-Data quality objectives for groundwater, surface water, and sediment sampling and analysis, Jefferson Proving Ground, Madison, Indiana: Submitted to the U.S. Department of Army Installation Support Management Activity, Aberdeen Proving Ground, Md., and U.S. Army Corps of Engineers, Louisville District, $82 \mathrm{p}$.

Shaver, R.H., Ault, C.H., Burger, A.M., Carr, D.D., Droste, J.B., Eggert, D.L., Gray, H.H., Harper, Denver, Hasenmueller, N.R., Hasenmueller, W.A., Horowitz, A.S., Hutchison, H.C., Keith, B.D., Keller, S.J., Patton, J.B., Rexroad, C.B., and Wier, C.E., 1986, Compendium of Paleozoic rock-unit stratigraphy in Indiana-A revision: Indiana Geological Survey Bulletin 59, 203 p., 2 pl., accessed July 1, 2009, at http://igs.indiana.edu/Geology/ structure/compendium/html/.

Sheldon, Ray, 1997, Jefferson Proving Ground karst study: Indiana Cave Survey, 405 p.

Smart, P.L., and Hobbs, S.L., 1986, Characterization of carbonate aquifers-A conceptual base, in Conference on Environmental Problems in Karst Terranes and Their Solutions, Bowling Green, Ky., October 28-30, 1986, Proceedings: Dublin, Ohio, National Water Well Association, p. 1-14.

Smith, Barry, 2001, Depleted uranium-Sources, exposure and Health Effects: Geneva, Switzerland, Department of Protection of the Human Environment, World Health Organization, accessed November 10, 2008, at http:// whqlibdoc.who.int/hq/2001/WHO_SDE_PHE_01.1.pdf.

Thatcher, L.L., 1962, The distribution of tritium fallout in precipitation over North America: Lovain, International Association of Hydrological Sciences Publication No. 7, p. $48-58$.

Thatcher, L.L., Janzer, V.J., and Edwards, K.W., 1977, Tritium-Electrolytic enrichment-Liquid scintillation method, Reston lab (R-1174-76), in Methods for determination of radioactive substances in water and fluvial sediments: U.S. Geological Survey Techniques of WaterResources Investigations, book 5, chap. A5, 1977, p. 79-81.

U.S. Army Corps of Engineers, 2008, Environmental quality: Environmental Statistics Manual No. 1110-1-4014, 544 p., accessed August 19, 2009, at http://140.194.76.129/ publications/eng-manuals/em1110-1-4014/entire.pdf.

U.S. Department of the Army, 2005, Jefferson Proving Ground Installation Support Management Agency-History and Depleted uranium pages, accessed July 7, 2009, at http://www.jpgbrac.com/history/history.htm and http://www. jpgbrac.com/uranium/du.htm.

U.S. Geological Survey, 1959, San Jacinto, Ind., quadrangle: 1:24,000 scale topographic map, minor revision 1994, 1 sheet. 
U.S. Geological Survey, 1992, Clifty Falls, Ind., quadrangle: 1:24,000 scale topographic map, 1 sheet.

U.S. Geological Survey, 2009a, Dissolved gas analysis: Reston, Va., The Reston Chlorofluorocarbon Laboratory, accessed May 21, 2009, at URL http://water.usgs.gov/lab/ dissolved-gas/.

U.S. Geological Survey, 2009b, Chlorofluorocarbon analysis: Reston, Va., The Reston Chlorofluorocarbon Laboratory, accessed January 12, 2009, at http://water.usgs.gov/lab/ chlorofluorocarbons/.

U.S. Geological Survey, 2009c, Dissolved gas sampling instructions-Collection and analysis of ground-water samples for helium by gas chromatography: Reston, Va.,
The Reston Chlorofluorocarbon Laboratory, accessed May 21, 2009, at http://water.usgs.gov/lab/dissolved-gas/ sampling/\#hel.

Weiss, R.F., 1970, The solubility of nitrogen, oxygen, and argon in water and seawater: Deep Sea Research, v. 17, no. 4 , p. 721-735.

Wilson, J.T., Mandell, W.A., Paillet, F.L., Bayless, E.R., Hanson, R.T., Kearl, P.M., Kerfoot, W.B., Newhouse, M.W., and Pedler, W.H., 2001, An evaluation of borehole flowmeters used to measure horizontal ground-water flow in limestones of Indiana, Kentucky, and Tennessee, 1999: U.S. Geological Survey Water-Resources Investigations Report 01-4139, 129 p. 


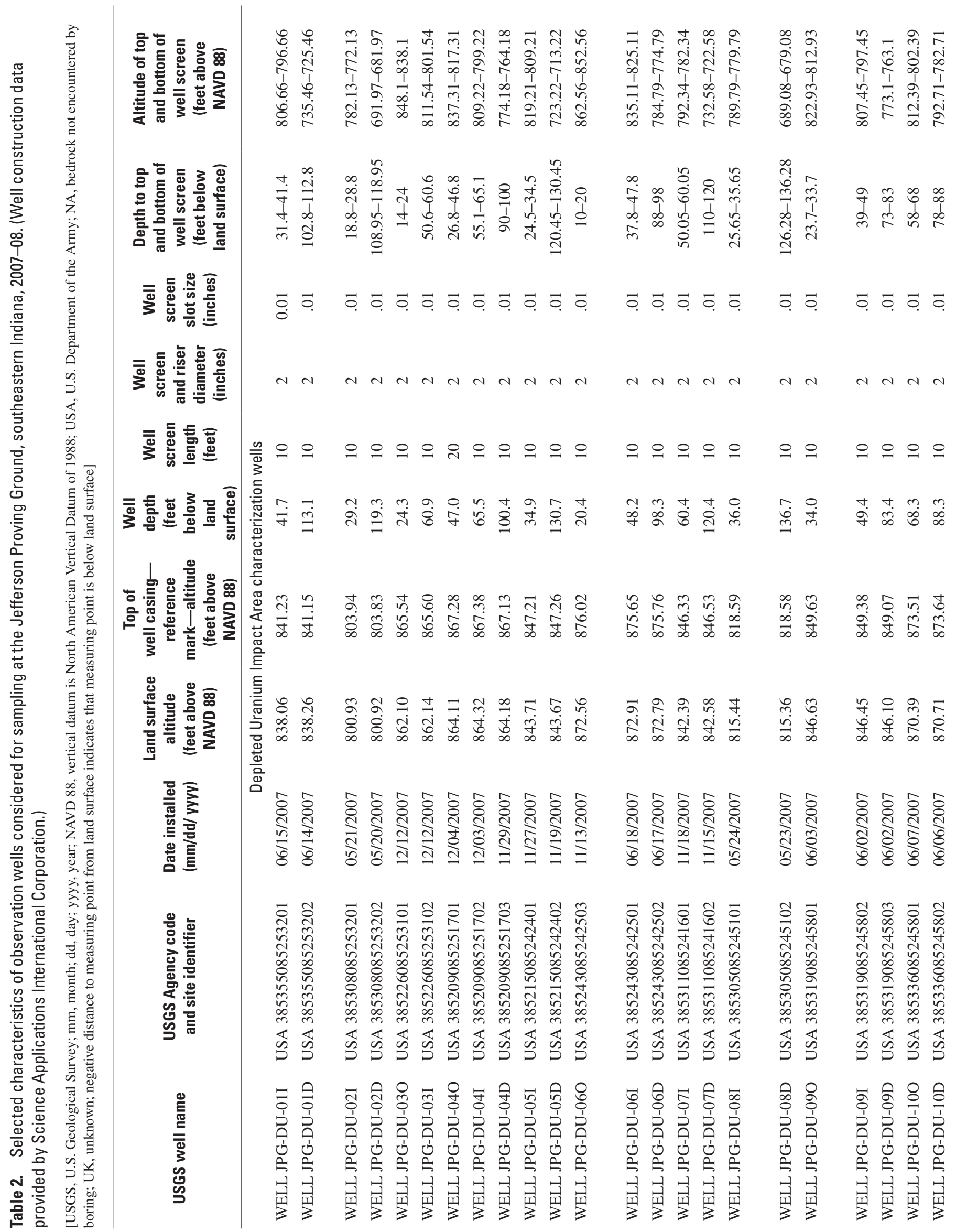




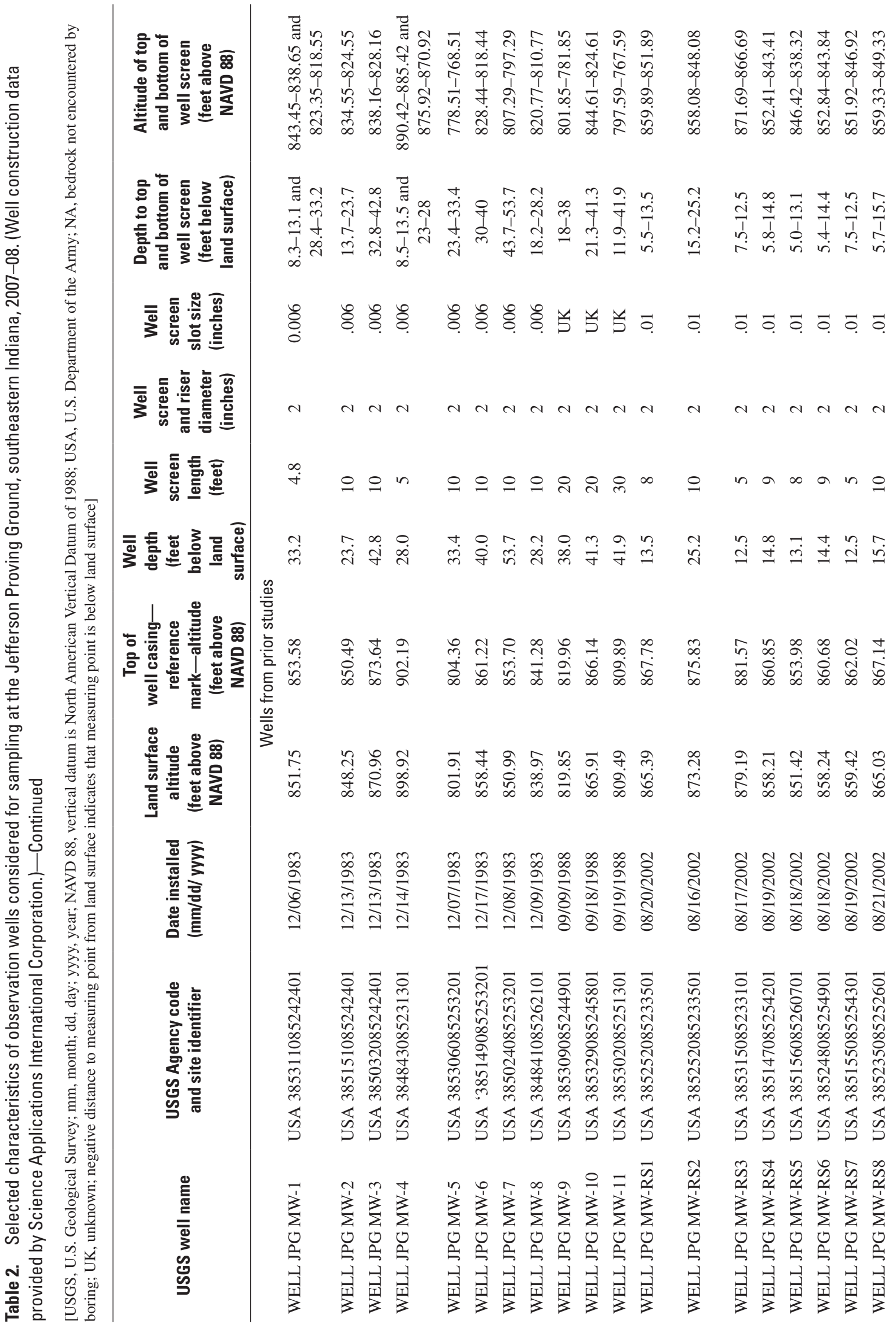




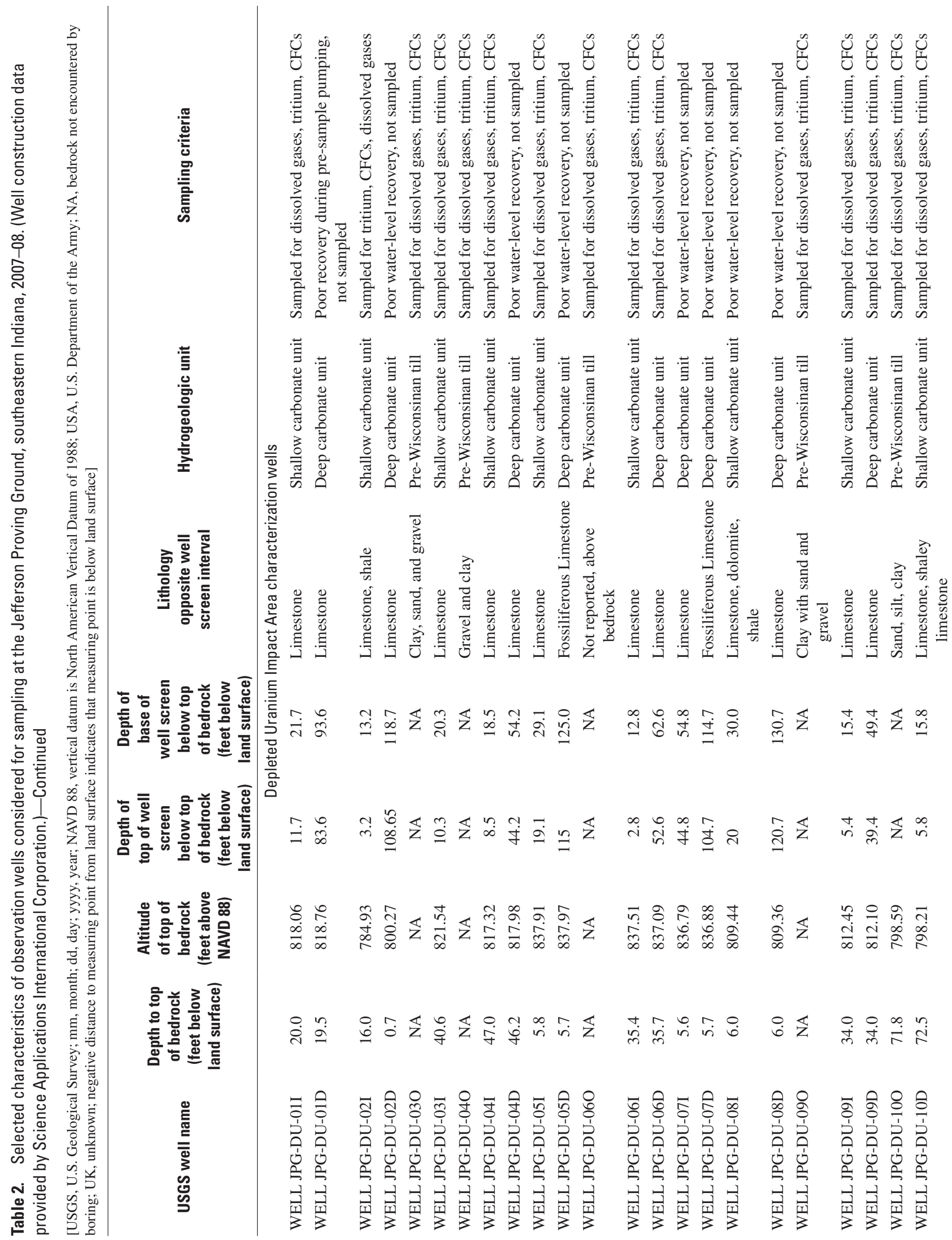




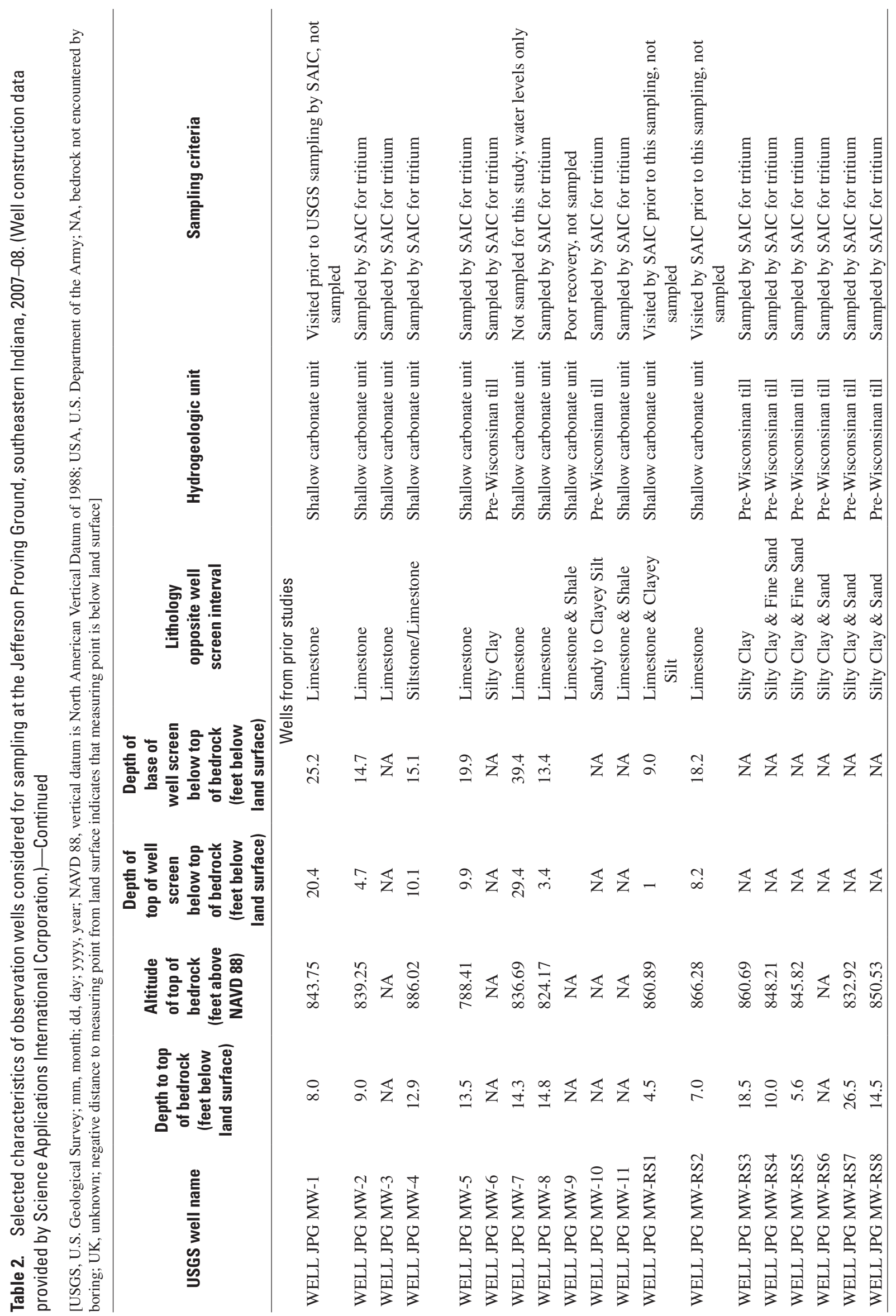


Table 5. Groundwater levels measured by the U.S. Geological Survey and Science Applications International Corporation (selected dates) in wells in the Pre-Wisconsinan till and in the shallow and deep carbonate units at the Jefferson Proving Ground, southeastern Indiana, 2007-08.

[USGS, U.S. Geological Survey; NAVD 88, North American Vertical Datum of 1988; mm/dd/yyyy, month/day/year; hh, hours; mm, minutes; -, negative depths to water indicate water levels above land surface; NR, not reported; SAIC, Science Applications International Corporation; NA, no recharge altitude estimated because no age-dating samples were collected from well; Dry, no water in well at time of measurement; --, no value]

\begin{tabular}{|c|c|c|c|c|c|c|c|c|}
\hline $\begin{array}{l}\text { USGS agency code and } \\
\text { site identifier }\end{array}$ & USGS well name & $\begin{array}{c}\text { Land } \\
\text { surface } \\
\text { altitude } \\
\text { (feet } \\
\text { above } \\
\text { NAVD 88) }\end{array}$ & $\begin{array}{l}\text { Water } \\
\text { level } \\
\text { (feet } \\
\text { below } \\
\text { land } \\
\text { surface) }\end{array}$ & $\begin{array}{c}\text { Water- } \\
\text { level } \\
\text { altitude } \\
\text { (feet } \\
\text { above } \\
\text { NAVD 88) }\end{array}$ & $\begin{array}{c}\text { Measure- } \\
\text { ment date } \\
\text { (mm/dd/yyyy) }\end{array}$ & $\begin{array}{c}\text { Measure- } \\
\text { ment time } \\
\text { (hhmm) }\end{array}$ & $\begin{array}{l}\text { Measure- } \\
\text { ment } \\
\text { source }\end{array}$ & $\begin{array}{l}\text { Estimated } \\
\text { recharge } \\
\text { altitude } \\
\text { (feet above } \\
\text { NAVD 88) }\end{array}$ \\
\hline \multirow[t]{10}{*}{ USA 385355085253201} & \multirow[t]{10}{*}{ WELL JPG-DU-01I } & \multirow[t]{10}{*}{838.06} & -0.48 & 838.54 & $06 / 20 / 2007$ & $16: 24$ & USGS & \multirow[t]{10}{*}{850} \\
\hline & & & -.96 & 839.02 & 09/12/2007 & 09:57 & USGS & \\
\hline & & & -1.05 & 839.11 & $01 / 07 / 2008$ & NR & USGS & \\
\hline & & & -1.06 & 839.12 & 01/09/2008 & $12: 46$ & USGS & \\
\hline & & & -.67 & 838.73 & 04/07/2008 & $11: 20$ & SAIC & \\
\hline & & & -1.40 & 839.46 & 05/05/2008 & $12: 57$ & USGS & \\
\hline & & & -1.53 & 839.59 & 05/09/2008 & $08: 17$ & USGS & \\
\hline & & & -1.58 & 839.64 & $05 / 13 / 2008$ & $15: 50$ & USGS & \\
\hline & & & -1.06 & 839.12 & 08/18/2008 & $10: 22$ & USGS & \\
\hline & & & -.87 & 838.93 & $08 / 22 / 2008$ & $12: 15$ & USGS & \\
\hline \multirow[t]{8}{*}{ USA 385355085253202} & \multirow[t]{8}{*}{ WELL JPG-DU-01D } & \multirow[t]{8}{*}{838.26} & 109.94 & 727.77 & $06 / 21 / 2007$ & NR & USGS & \multirow[t]{8}{*}{ NA } \\
\hline & & & 77.28 & 760.43 & 09/12/2007 & 09:57 & USGS & \\
\hline & & & 77.18 & 760.53 & 09/12/2007 & $14: 04$ & USGS & \\
\hline & & & 35.23 & 802.48 & 01/07/2008 & NR & USGS & \\
\hline & & & 34.66 & 803.05 & 01/09/2008 & $12: 46$ & USGS & \\
\hline & & & 9.25 & 829.01 & 04/07/2008 & $11: 18$ & SAIC & \\
\hline & & & 6.86 & 830.85 & 05/05/2008 & $12: 59$ & USGS & \\
\hline & & & 5.19 & 832.52 & 05/09/2008 & $08: 22$ & USGS & \\
\hline \multirow[t]{14}{*}{ USA 385308085253201} & \multirow[t]{14}{*}{ WELL JPG-DU-02I } & \multirow[t]{14}{*}{800.93} & 16.33 & 783.85 & $06 / 21 / 2007$ & $09: 35$ & USGS & \multirow[t]{14}{*}{810} \\
\hline & & & 16.96 & 783.22 & 09/12/2007 & $09: 27$ & USGS & \\
\hline & & & 16.97 & 783.21 & 09/12/2007 & $14: 17$ & USGS & \\
\hline & & & Dry & -- & 01/07/2008 & $11: 26$ & USGS & \\
\hline & & & Dry & -- & 01/09/2008 & $12: 18$ & USGS & \\
\hline & & & 15.07 & 785.86 & 04/07/2008 & $12: 23$ & SAIC & \\
\hline & & & 15.66 & 784.52 & 05/05/2008 & $12: 51$ & USGS & \\
\hline & & & 14.20 & 785.98 & 05/09/2008 & $09: 13$ & USGS & \\
\hline & & & 14.72 & 785.46 & 05/13/2008 & $14: 46$ & USGS & \\
\hline & & & 9.61 & 790.57 & 05/16/2008 & 08:00 & USGS & \\
\hline & & & 13.25 & 786.93 & 05/17/2008 & $12: 35$ & USGS & \\
\hline & & & 16.20 & 784.73 & 07/14/2008 & $13: 30$ & SAIC & \\
\hline & & & 16.42 & 783.76 & 08/18/2008 & $10: 14$ & USGS & \\
\hline & & & 16.48 & 783.70 & 08/22/2008 & $11: 45$ & USGS & \\
\hline
\end{tabular}


Table 5. Groundwater levels measured by the U.S. Geological Survey and Science Applications International Corporation (selected dates) in wells in the Pre-Wisconsinan till and in the shallow and deep carbonate units at the Jefferson Proving Ground, southeastern Indiana, 2007-08.-Continued

[USGS, U.S. Geological Survey; NAVD 88, North American Vertical Datum of 1988; mm/dd/yyyy, month/day/year; hh, hours; mm, minutes; -, negative depths to water indicate water levels above land surface; NR, not reported; SAIC, Science Applications International Corporation; NA, no recharge altitude estimated because no age-dating samples were collected from well; Dry, no water in well at time of measurement; --, no value]

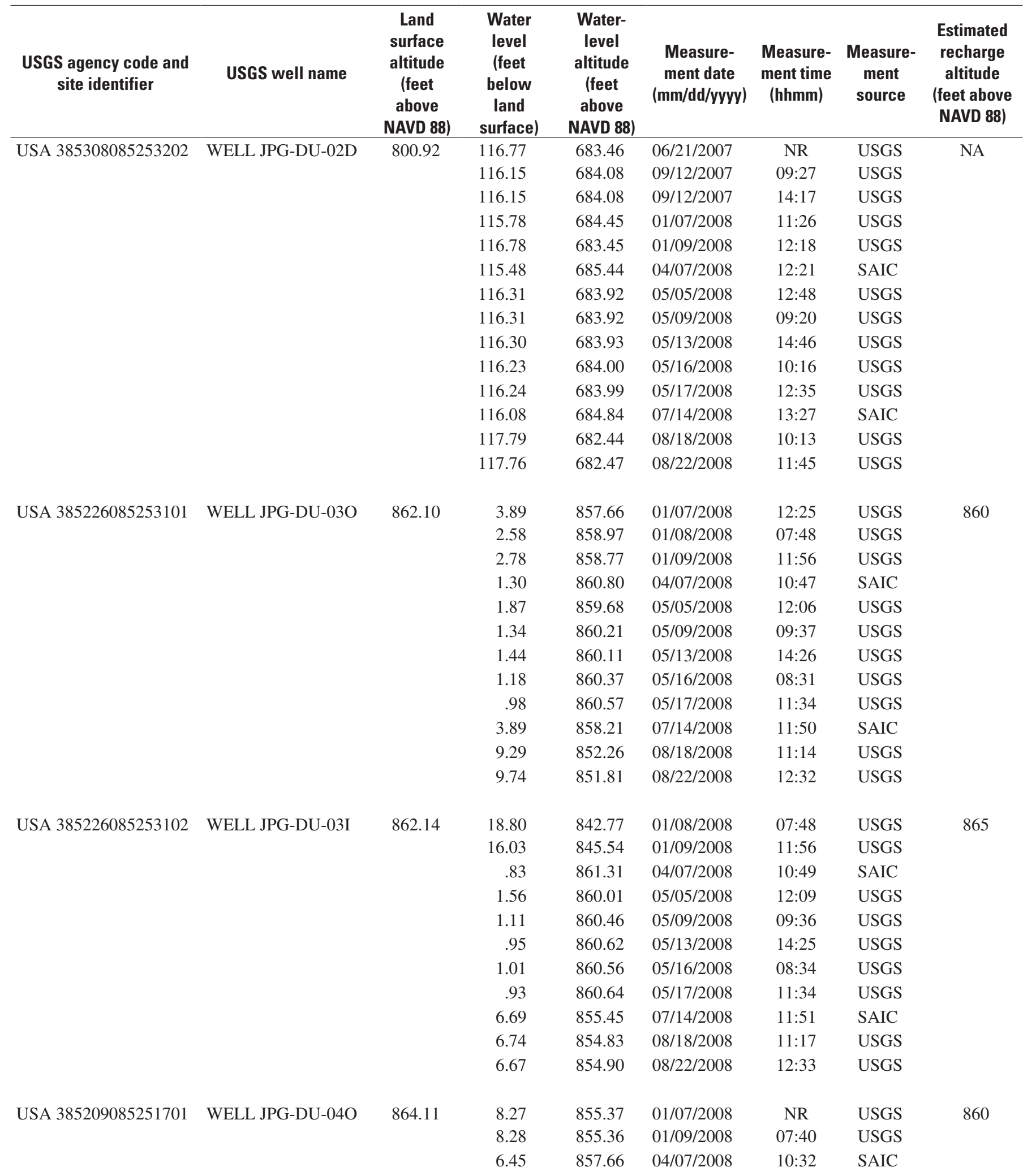


Table 5. Groundwater levels measured by the U.S. Geological Survey and Science Applications International Corporation (selected dates) in wells in the Pre-Wisconsinan till and in the shallow and deep carbonate units at the Jefferson Proving Ground, southeastern Indiana, 2007-08.-Continued

[USGS, U.S. Geological Survey; NAVD 88, North American Vertical Datum of 1988; mm/dd/yyyy, month/day/year; hh, hours; mm, minutes; -, negative depths to water indicate water levels above land surface; NR, not reported; SAIC, Science Applications International Corporation; NA, no recharge altitude estimated because no age-dating samples were collected from well; Dry, no water in well at time of measurement; --, no value]

\begin{tabular}{|c|c|c|c|c|c|c|c|c|}
\hline $\begin{array}{l}\text { USGS agency code and } \\
\text { site identifier }\end{array}$ & USGS well name & $\begin{array}{c}\text { Land } \\
\text { surface } \\
\text { altitude } \\
\text { (feet } \\
\text { above } \\
\text { NAVD 88) }\end{array}$ & $\begin{array}{c}\text { Water } \\
\text { level } \\
\text { (feet } \\
\text { below } \\
\text { land } \\
\text { surface) }\end{array}$ & $\begin{array}{c}\text { Water- } \\
\text { level } \\
\text { altitude } \\
\text { (feet } \\
\text { above } \\
\text { NAVD 88) }\end{array}$ & $\begin{array}{c}\text { Measure- } \\
\text { ment date } \\
\text { (mm/dd/yyyy) }\end{array}$ & $\begin{array}{c}\text { Measure- } \\
\text { ment time } \\
\text { (hhmm) }\end{array}$ & $\begin{array}{l}\text { Measure- } \\
\text { ment } \\
\text { source }\end{array}$ & $\begin{array}{l}\text { Estimated } \\
\text { recharge } \\
\text { altitude } \\
\text { (feet above } \\
\text { NAVD 88) }\end{array}$ \\
\hline \multirow{6}{*}{\multicolumn{2}{|c|}{ USA 385209085251701 - Continued }} & & 7.06 & 856.58 & $05 / 05 / 2008$ & $12: 20$ & USGS & \\
\hline & & & 6.74 & 856.90 & 05/09/2008 & $07: 53$ & USGS & \\
\hline & & & 6.68 & 856.96 & 05/17/2008 & $11: 43$ & USGS & \\
\hline & & & 8.69 & 855.42 & $07 / 14 / 2008$ & $11: 41$ & SAIC & \\
\hline & & & 1.18 & 853.46 & 08/18/2008 & $11: 28$ & USGS & \\
\hline & & & 1.37 & 853.27 & $08 / 22 / 2008$ & $10: 51$ & USGS & \\
\hline \multirow{7}{*}{ USA 385209085251702} & & & 7.51 & 856.40 & 05/09/2008 & $07: 48$ & USGS & \\
\hline & & & 7.57 & 856.34 & 05/13/2008 & $13: 17$ & USGS & \\
\hline & & & 8.55 & 855.36 & 05/16/2008 & $08: 44$ & USGS & \\
\hline & & & 7.46 & 856.45 & 05/17/2008 & $11: 43$ & USGS & \\
\hline & & & 9.63 & 854.69 & 07/14/2008 & $11: 40$ & SAIC & \\
\hline & & & 11.10 & 852.81 & 08/18/2008 & $11: 27$ & USGS & \\
\hline & & & 11.24 & 852.67 & $08 / 22 / 2008$ & $10: 51$ & USGS & \\
\hline \multirow[t]{4}{*}{ USA 385209085251703} & WELL JPG-DU-04D & 864.18 & 8.80 & 782.81 & 01/07/2008 & NR & USGS & NA \\
\hline & & & 8.27 & 783.34 & 01/09/2008 & $07: 35$ & USGS & \\
\hline & & & 52.01 & 811.60 & 08/18/2008 & $11: 25$ & USGS & \\
\hline & & & 51.43 & 812.18 & 08/22/2008 & $10: 52$ & USGS & \\
\hline \multirow[t]{11}{*}{ USA 385215085242401} & WELL JPG-DU-05I & 843.71 & 2.47 & 840.68 & 01/07/2008 & NR & USGS & 860 \\
\hline & & & 1.41 & 841.74 & 01/09/2008 & $09: 27$ & USGS & \\
\hline & & & 2.33 & 841.38 & 04/07/2008 & 11:03 & SAIC & \\
\hline & & & 2.87 & 840.28 & 05/05/2008 & $13: 59$ & USGS & \\
\hline & & & 1.62 & 841.53 & 05/09/2008 & $06: 35$ & USGS & \\
\hline & & & 1.94 & 841.21 & 05/13/2008 & $13: 42$ & USGS & \\
\hline & & & .54 & 842.61 & 05/16/2008 & $08: 54$ & USGS & \\
\hline & & & 1.44 & 841.71 & 05/17/2008 & $11: 52$ & USGS & \\
\hline & & & 3.35 & 840.36 & 07/14/2008 & $11: 24$ & SAIC & \\
\hline & & & 3.94 & 839.21 & 08/18/2008 & $11: 37$ & USGS & \\
\hline & & & 4.04 & 839.11 & 08/22/2008 & $11: 21$ & USGS & \\
\hline
\end{tabular}


Table 5. Groundwater levels measured by the U.S. Geological Survey and Science Applications International Corporation (selected dates) in wells in the Pre-Wisconsinan till and in the shallow and deep carbonate units at the Jefferson Proving Ground, southeastern Indiana, 2007-08.-Continued

[USGS, U.S. Geological Survey; NAVD 88, North American Vertical Datum of 1988; mm/dd/yyyy, month/day/year; hh, hours; mm, minutes; -, negative depths to water indicate water levels above land surface; NR, not reported; SAIC, Science Applications International Corporation; NA, no recharge altitude estimated because no age-dating samples were collected from well; Dry, no water in well at time of measurement; --, no value]

\begin{tabular}{|c|c|c|c|c|c|c|c|c|}
\hline $\begin{array}{l}\text { USGS agency code and } \\
\text { site identifier }\end{array}$ & USGS well name & $\begin{array}{c}\text { Land } \\
\text { surface } \\
\text { altitude } \\
\text { (feet } \\
\text { above } \\
\text { NAVD 88) }\end{array}$ & $\begin{array}{l}\text { Water } \\
\text { level } \\
\text { (feet } \\
\text { below } \\
\text { land } \\
\text { surface) }\end{array}$ & $\begin{array}{l}\text { Water- } \\
\text { level } \\
\text { altitude } \\
\text { (feet } \\
\text { above } \\
\text { NAVD 88) }\end{array}$ & $\begin{array}{c}\text { Measure- } \\
\text { ment date } \\
\text { (mm/dd/yyyy) }\end{array}$ & $\begin{array}{l}\text { Measure- } \\
\text { ment time } \\
\text { (hhmm) }\end{array}$ & $\begin{array}{l}\text { Measure- } \\
\text { ment } \\
\text { source }\end{array}$ & $\begin{array}{l}\text { Estimated } \\
\text { recharge } \\
\text { altitude } \\
\text { (feet above } \\
\text { NAVD 88) }\end{array}$ \\
\hline \multirow[t]{7}{*}{ USA 385215085242402} & \multirow[t]{7}{*}{ WELL JPG-DU-05D } & \multirow[t]{7}{*}{843.67} & 118.11 & 725.02 & $01 / 07 / 2008$ & NR & USGS & \multirow[t]{7}{*}{ NA } \\
\hline & & & 118.18 & 724.95 & 01/09/2008 & $09: 30$ & USGS & \\
\hline & & & 121.12 & 722.01 & 05/05/2008 & $14: 00$ & USGS & \\
\hline & & & 121.11 & 722.02 & 05/09/2008 & 06:41 & USGS & \\
\hline & & & 121.12 & 722.01 & 05/13/2008 & $13: 43$ & USGS & \\
\hline & & & 121.13 & 722.00 & 05/16/2008 & $08: 58$ & USGS & \\
\hline & & & 12.99 & 722.14 & 05/17/2008 & $11: 52$ & USGS & \\
\hline \multirow[t]{10}{*}{ USA 385243085242503} & \multirow[t]{10}{*}{ WELL JPG-DU-06O } & \multirow[t]{10}{*}{872.56} & 2.11 & 869.83 & 01/07/2008 & NR & USGS & \multirow[t]{10}{*}{870} \\
\hline & & & 2.10 & 869.84 & 01/09/2008 & $11: 30$ & USGS & \\
\hline & & & .64 & 871.92 & 04/07/2008 & $10: 52$ & SAIC & \\
\hline & & & 1.14 & 870.80 & 05/05/2008 & $14: 10$ & USGS & \\
\hline & & & .67 & 871.27 & 05/09/2008 & $10: 10$ & USGS & \\
\hline & & & .84 & 871.10 & 05/13/2008 & $13: 53$ & USGS & \\
\hline & & & .57 & 871.37 & 05/16/2008 & 09:08 & USGS & \\
\hline & & & .37 & 871.57 & 05/17/2008 & $11: 58$ & USGS & \\
\hline & & & 5.08 & 867.48 & 07/14/2008 & $11: 31$ & SAIC & \\
\hline & & & 7.12 & 864.82 & 08/18/2008 & $11: 44$ & USGS & \\
\hline \multirow{11}{*}{ USA 385243085242501} & \multirow{11}{*}{ WELL JPG-DU-06I } & \multirow{11}{*}{872.91} & 7.98 & 864.56 & 01/07/2008 & NR & USGS & \multirow{11}{*}{870} \\
\hline & & & 7.91 & 864.63 & 01/09/2008 & $11: 30$ & USGS & \\
\hline & & & 4.42 & 868.49 & 04/07/2008 & $10: 50$ & SAIC & \\
\hline & & & 4.35 & 868.19 & 05/05/2008 & $14: 10$ & USGS & \\
\hline & & & 4.06 & 868.48 & 05/09/2008 & $10: 16$ & USGS & \\
\hline & & & 4.09 & 868.45 & 05/13/2008 & $13: 52$ & USGS & \\
\hline & & & 3.99 & 868.55 & 05/16/2008 & 09:02 & USGS & \\
\hline & & & 3.87 & 868.67 & 05/17/2008 & $11: 59$ & USGS & \\
\hline & & & 8.59 & 864.32 & 07/14/2008 & $11: 35$ & SAIC & \\
\hline & & & 1.90 & 861.64 & 08/18/2008 & $11: 49$ & USGS & \\
\hline & & & 11.16 & 861.38 & $08 / 22 / 2008$ & $11: 13$ & USGS & \\
\hline
\end{tabular}


Table 5. Groundwater levels measured by the U.S. Geological Survey and Science Applications International Corporation (selected dates) in wells in the Pre-Wisconsinan till and in the shallow and deep carbonate units at the Jefferson Proving Ground, southeastern Indiana, 2007-08.-Continued

[USGS, U.S. Geological Survey; NAVD 88, North American Vertical Datum of 1988; mm/dd/yyyy, month/day/year; hh, hours; mm, minutes; -, negative depths to water indicate water levels above land surface; NR, not reported; SAIC, Science Applications International Corporation; NA, no recharge altitude estimated because no age-dating samples were collected from well; Dry, no water in well at time of measurement; --, no value]

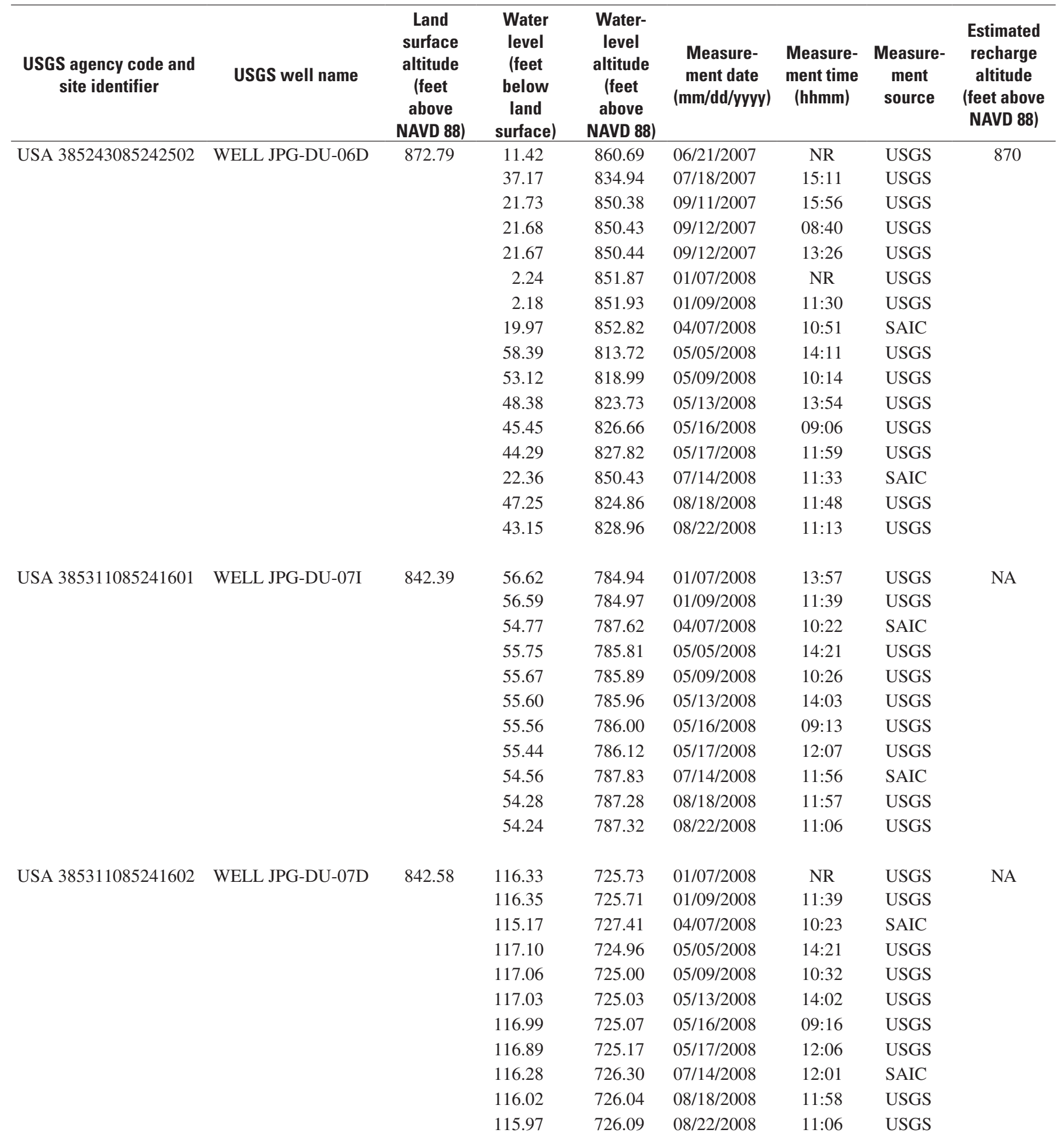


Table 5. Groundwater levels measured by the U.S. Geological Survey and Science Applications International Corporation (selected dates) in wells in the Pre-Wisconsinan till and in the shallow and deep carbonate units at the Jefferson Proving Ground, southeastern Indiana, 2007-08.-Continued

[USGS, U.S. Geological Survey; NAVD 88, North American Vertical Datum of 1988; mm/dd/yyyy, month/day/year; hh, hours; mm, minutes; -, negative depths to water indicate water levels above land surface; NR, not reported; SAIC, Science Applications International Corporation; NA, no recharge altitude estimated because no age-dating samples were collected from well; Dry, no water in well at time of measurement; --, no value]

\begin{tabular}{|c|c|c|c|c|c|c|c|c|}
\hline $\begin{array}{l}\text { USGS agency code and } \\
\text { site identifier }\end{array}$ & USGS well name & $\begin{array}{c}\text { Land } \\
\text { surface } \\
\text { altitude } \\
\text { (feet } \\
\text { above } \\
\text { NAVD 88) }\end{array}$ & $\begin{array}{c}\text { Water } \\
\text { level } \\
\text { (feet } \\
\text { below } \\
\text { land } \\
\text { surface) }\end{array}$ & $\begin{array}{l}\text { Water- } \\
\text { level } \\
\text { altitude } \\
\text { (feet } \\
\text { above } \\
\text { NAVD 88) }\end{array}$ & $\begin{array}{c}\text { Measure- } \\
\text { ment date } \\
\text { (mm/dd/yyyy) }\end{array}$ & $\begin{array}{l}\text { Measure- } \\
\text { ment time } \\
\text { (hhmm) }\end{array}$ & $\begin{array}{l}\text { Measure- } \\
\text { ment } \\
\text { source }\end{array}$ & $\begin{array}{l}\text { Estimated } \\
\text { recharge } \\
\text { altitude } \\
\text { (feet above } \\
\text { NAVD 88) }\end{array}$ \\
\hline \multirow[t]{7}{*}{ USA 385305085245101} & \multirow[t]{7}{*}{ WELL JPG-DU-08I } & \multirow{7}{*}{815.44} & Dry & -- & 06/20/2007 & NR & USGS & \multirow[t]{7}{*}{ NA } \\
\hline & & & 21.57 & 793.16 & 01/07/2008 & NR & USGS & \\
\hline & & & 18.28 & 797.16 & 04/07/2008 & $12: 31$ & SAIC & \\
\hline & & & 35.74 & 778.99 & 05/05/2008 & $13: 25$ & USGS & \\
\hline & & & 35.28 & 779.45 & 05/09/2008 & 08:59 & USGS & \\
\hline & & & 35.41 & 779.32 & 05/13/2008 & $15: 17$ & USGS & \\
\hline & & & 35.22 & 779.51 & 05/16/2008 & 09:55 & USGS & \\
\hline \multirow[t]{9}{*}{ USA 385305085245102} & \multirow[t]{9}{*}{ WELL JPG-DU-08D } & \multirow[t]{9}{*}{815.36} & 134.53 & 679.97 & 06/20/2007 & NR & USGS & \multirow[t]{9}{*}{ NA } \\
\hline & & & 133.13 & 681.37 & 01/07/2008 & NR & USGS & \\
\hline & & & 133.12 & 681.38 & 01/09/2008 & $12: 23$ & USGS & \\
\hline & & & 132.67 & 682.69 & 04/07/2008 & $12: 36$ & SAIC & \\
\hline & & & 134.45 & 680.05 & 05/05/2008 & $13: 26$ & USGS & \\
\hline & & & 134.42 & 680.08 & 05/09/2008 & 09:04 & USGS & \\
\hline & & & 134.41 & 680.09 & 05/13/2008 & $15: 39$ & USGS & \\
\hline & & & 134.35 & 680.15 & 05/16/2008 & $10: 00$ & USGS & \\
\hline & & & 134.34 & 680.16 & 05/17/2008 & $12: 42$ & USGS & \\
\hline \multirow{9}{*}{ USA 385319085245801} & \multirow{9}{*}{ WELL JPG-DU-09O } & \multirow{9}{*}{846.63} & 8.97 & 837.66 & 04/07/2008 & $11: 35$ & SAIC & \multirow{9}{*}{840} \\
\hline & & & 9.16 & 836.84 & 05/05/2008 & $13: 12$ & USGS & \\
\hline & & & 8.96 & 837.04 & 05/09/2008 & $08: 42$ & USGS & \\
\hline & & & 17.91 & 828.09 & 05/13/2008 & $15: 11$ & USGS & \\
\hline & & & 8.72 & 837.28 & 05/16/2008 & 09:49 & USGS & \\
\hline & & & 8.72 & 837.28 & 05/17/2008 & $12: 51$ & USGS & \\
\hline & & & 8.84 & 837.79 & 07/14/2008 & $12: 32$ & SAIC & \\
\hline & & & 9.37 & 836.63 & 08/18/2008 & $10: 46$ & USGS & \\
\hline & & & 9.45 & 836.55 & 08/22/2008 & $12: 00$ & USGS & \\
\hline \multirow[t]{4}{*}{ USA 385319085245802} & \multirow[t]{4}{*}{ WELL JPG-DU-09I } & \multirow[t]{4}{*}{846.45} & 2.27 & 825.55 & 06/20/2007 & $15: 57$ & USGS & \multirow[t]{4}{*}{845} \\
\hline & & & 14.24 & 831.58 & 07/18/2007 & $08: 13$ & USGS & \\
\hline & & & 13.61 & 832.21 & 01/09/2008 & $12: 32$ & USGS & \\
\hline & & & 13.58 & 832.87 & 04/07/2008 & $11: 36$ & SAIC & \\
\hline
\end{tabular}


Table 5. Groundwater levels measured by the U.S. Geological Survey and Science Applications International Corporation (selected dates) in wells in the Pre-Wisconsinan till and in the shallow and deep carbonate units at the Jefferson Proving Ground, southeastern Indiana, 2007-08.-Continued

[USGS, U.S. Geological Survey; NAVD 88, North American Vertical Datum of 1988; mm/dd/yyyy, month/day/year; hh, hours; mm, minutes; -, negative depths to water indicate water levels above land surface; NR, not reported; SAIC, Science Applications International Corporation; NA, no recharge altitude estimated because no age-dating samples were collected from well; Dry, no water in well at time of measurement; --, no value]

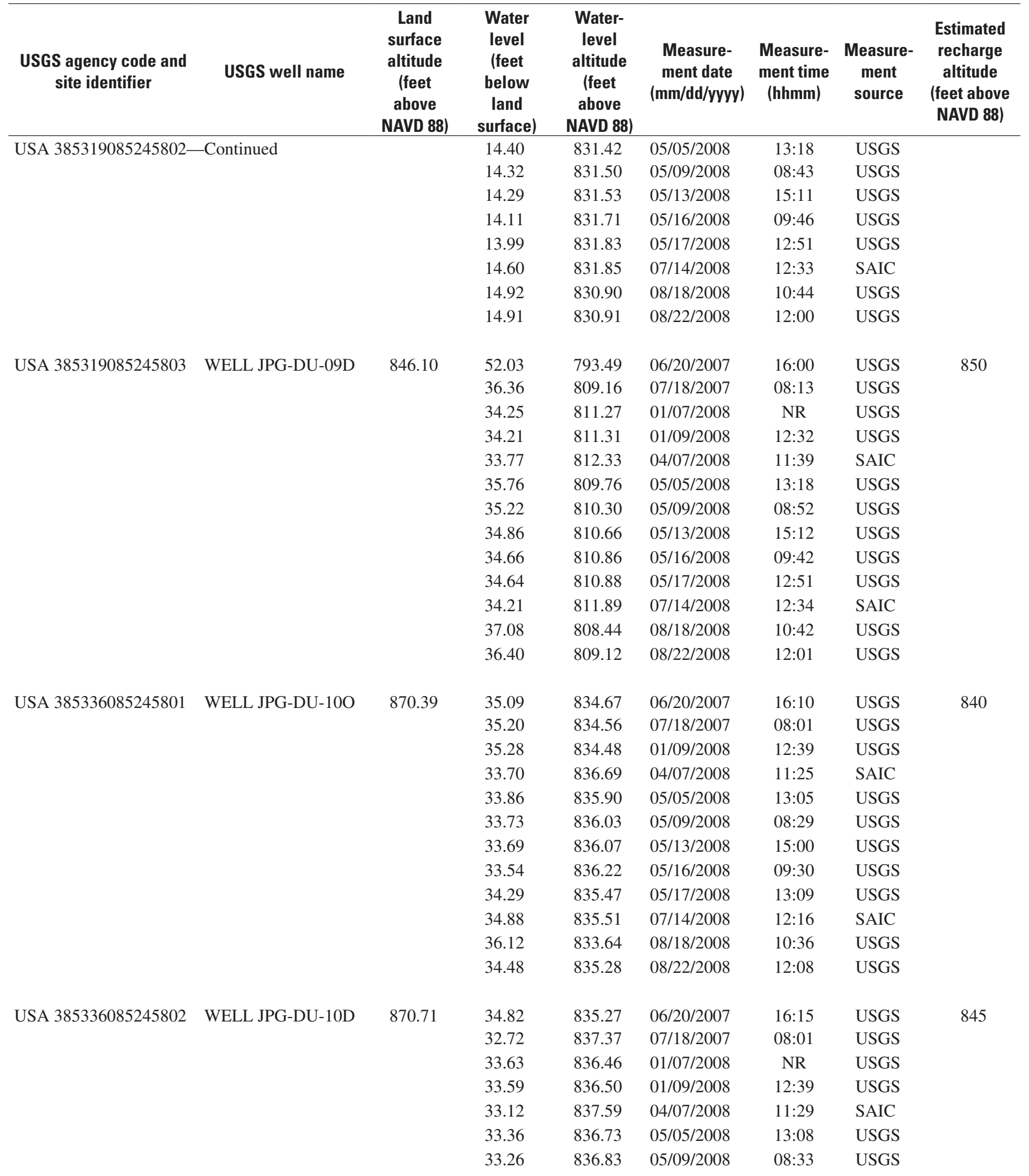


Table 5. Groundwater levels measured by the U.S. Geological Survey and Science Applications International Corporation (selected dates) in wells in the Pre-Wisconsinan till and in the shallow and deep carbonate units at the Jefferson Proving Ground, southeastern Indiana, 2007-08.-Continued

[USGS, U.S. Geological Survey; NAVD 88, North American Vertical Datum of 1988; mm/dd/yyyy, month/day/year; hh, hours; mm, minutes; -, negative depths to water indicate water levels above land surface; NR, not reported; SAIC, Science Applications International Corporation; NA, no recharge altitude estimated because no age-dating samples were collected from well; Dry, no water in well at time of measurement; --, no value]

\begin{tabular}{|c|c|c|c|c|c|c|c|c|}
\hline $\begin{array}{l}\text { USGS agency code and } \\
\text { site identifier }\end{array}$ & USGS well name & $\begin{array}{c}\text { Land } \\
\text { surface } \\
\text { altitude } \\
\text { (feet } \\
\text { above } \\
\text { NAVD 88) }\end{array}$ & $\begin{array}{l}\text { Water } \\
\text { level } \\
\text { (feet } \\
\text { below } \\
\text { land } \\
\text { surface) }\end{array}$ & $\begin{array}{l}\text { Water- } \\
\text { level } \\
\text { altitude } \\
\text { (feet } \\
\text { above } \\
\text { NAVD 88) }\end{array}$ & $\begin{array}{c}\text { Measure- } \\
\text { ment date } \\
\text { (mm/dd/yyyy) }\end{array}$ & $\begin{array}{l}\text { Measure- } \\
\text { ment time } \\
\text { (hhmm) }\end{array}$ & $\begin{array}{l}\text { Measure- } \\
\text { ment } \\
\text { source }\end{array}$ & $\begin{array}{l}\text { Estimated } \\
\text { recharge } \\
\text { altitude } \\
\text { (feet above } \\
\text { NAVD 88) }\end{array}$ \\
\hline \multirow{5}{*}{\multicolumn{2}{|c|}{ USA 385336085245802 -Continued }} & & 33.30 & 836.79 & $05 / 13 / 2008$ & $14: 59$ & USGS & \\
\hline & & & 33.21 & 836.88 & 05/16/2008 & 09:32 & USGS & \\
\hline & & & 33.51 & 837.20 & $07 / 14 / 2008$ & $12: 17$ & SAIC & \\
\hline & & & 34.53 & 835.56 & 08/18/2008 & $10: 33$ & USGS & \\
\hline & & & 36.44 & 833.65 & $08 / 22 / 2008$ & $12: 08$ & USGS & \\
\hline USA 385311085242401 & WELL JPG MW-1 & 851.75 & 7.87 & 843.88 & 04/07/2008 & $10: 26$ & SAIC & NA \\
\hline \multirow[t]{2}{*}{ USA 385032085242401} & WELL JPG MW-3 & 870.96 & 6.32 & 864.64 & 04/07/2008 & $10: 08$ & SAIC & NA \\
\hline & & & 9.27 & 861.69 & 07/14/2008 & $11: 22$ & SAIC & \\
\hline \multirow[t]{2}{*}{ USA 384843085231301} & WELL JPG MW-4 & 898.92 & .44 & 898.48 & 04/07/2008 & 09:46 & SAIC & NA \\
\hline & & & 5.10 & 893.82 & $07 / 14 / 2008$ & $10: 42$ & SAIC & \\
\hline \multirow[t]{2}{*}{ USA 385306085253201} & WELL JPG MW-5 & 801.91 & 15.95 & 785.96 & 04/07/2008 & 11:09 & SAIC & NA \\
\hline & & & 17.00 & 784.91 & $07 / 14 / 2008$ & $13: 34$ & SAIC & \\
\hline USA 384841085262101 & & & 21.33 & 817.64 & 07/14/2008 & $10: 55$ & SAIC & \\
\hline \multirow[t]{2}{*}{ USA 385309085244901} & WELL JPG MW-9 & 819.85 & 36.42 & 783.43 & 04/07/2008 & $12: 44$ & SAIC & NA \\
\hline & & & 36.58 & 783.27 & 07/14/2008 & $13: 54$ & SAIC & \\
\hline \multirow[t]{2}{*}{ USA 385329085245801} & WELL JPG MW-10 & 865.91 & 1.48 & 864.43 & 04/07/2008 & $11: 32$ & SAIC & NA \\
\hline & & & 6.93 & 858.98 & $07 / 14 / 2008$ & $12: 29$ & SAIC & \\
\hline \multirow[t]{2}{*}{ USA 385302085251301} & WELL JPG MW-11 & 809.94 & 5.37 & 804.57 & 04/07/2008 & $12: 27$ & SAIC & NA \\
\hline & & & 1.37 & 799.57 & 07/14/2008 & $13: 45$ & SAIC & \\
\hline \multirow[t]{2}{*}{ USA 385252085233501} & WELL JPG MW-RS1 & 865.39 & .03 & 865.36 & 04/07/2008 & $10: 04$ & SAIC & NA \\
\hline & & & .88 & 864.51 & $07 / 14 / 2008$ & $12: 23$ & SAIC & \\
\hline
\end{tabular}


Table 5. Groundwater levels measured by the U.S. Geological Survey and Science Applications International Corporation (selected dates) in wells in the Pre-Wisconsinan till and in the shallow and deep carbonate units at the Jefferson Proving Ground, southeastern Indiana, 2007-08.-Continued

[USGS, U.S. Geological Survey; NAVD 88, North American Vertical Datum of 1988; mm/dd/yyyy, month/day/year; hh, hours; mm, minutes; -, negative depths to water indicate water levels above land surface; NR, not reported; SAIC, Science Applications International Corporation; NA, no recharge altitude estimated because no age-dating samples were collected from well; Dry, no water in well at time of measurement; --, no value]

\begin{tabular}{|c|c|c|c|c|c|c|c|c|}
\hline $\begin{array}{l}\text { USGS agency code and } \\
\text { site identifier }\end{array}$ & USGS well name & $\begin{array}{c}\text { Land } \\
\text { surface } \\
\text { altitude } \\
\text { (feet } \\
\text { above } \\
\text { NAVD 88) }\end{array}$ & $\begin{array}{c}\text { Water } \\
\text { level } \\
\text { (feet } \\
\text { below } \\
\text { land } \\
\text { surface) }\end{array}$ & $\begin{array}{c}\text { Water- } \\
\text { level } \\
\text { altitude } \\
\text { (feet } \\
\text { above } \\
\text { NAVD 88) }\end{array}$ & $\begin{array}{c}\text { Measure- } \\
\text { ment date } \\
\text { (mm/dd/yyyy) }\end{array}$ & $\begin{array}{c}\text { Measure- } \\
\text { ment time } \\
\text { (hhmm) }\end{array}$ & $\begin{array}{l}\text { Measure- } \\
\text { ment } \\
\text { source }\end{array}$ & $\begin{array}{l}\text { Estimated } \\
\text { recharge } \\
\text { altitude } \\
\text { (feet above } \\
\text { NAVD 88) }\end{array}$ \\
\hline USA 385252085233501 & WELL JPG MW-RS2 & 873.28 & $\begin{array}{l}1.22 \\
5.42\end{array}$ & $\begin{array}{l}872.06 \\
867.86\end{array}$ & $\begin{array}{l}04 / 07 / 2008 \\
07 / 14 / 2008\end{array}$ & $\begin{array}{l}10: 12 \\
12: 13\end{array}$ & $\begin{array}{l}\text { SAIC } \\
\text { SAIC }\end{array}$ & NA \\
\hline USA 385315085233101 & WELL JPG MW-RS3 & 879.19 & $\begin{array}{l}3.36 \\
5.83\end{array}$ & $\begin{array}{l}875.83 \\
873.36\end{array}$ & $\begin{array}{l}04 / 07 / 2008 \\
07 / 14 / 2008\end{array}$ & $\begin{array}{l}10: 16 \\
12: 06\end{array}$ & $\begin{array}{l}\text { SAIC } \\
\text { SAIC }\end{array}$ & NA \\
\hline USA 385147085254201 & WELL JPG MW-RS4 & 858.21 & $\begin{array}{l}4.06 \\
5.82\end{array}$ & $\begin{array}{l}854.15 \\
852.39\end{array}$ & $\begin{array}{l}04 / 07 / 2008 \\
07 / 14 / 2008\end{array}$ & $\begin{array}{l}11: 54 \\
12: 58\end{array}$ & $\begin{array}{l}\text { SAIC } \\
\text { SAIC }\end{array}$ & NA \\
\hline USA 385248085254901 & WELL JPG MW-RS6 & 858.24 & $\begin{array}{l}2.67 \\
6.08\end{array}$ & $\begin{array}{l}855.57 \\
852.16\end{array}$ & $\begin{array}{l}04 / 07 / 2008 \\
07 / 14 / 2008\end{array}$ & $\begin{array}{l}12: 13 \\
13: 04\end{array}$ & $\begin{array}{l}\text { SAIC } \\
\text { SAIC }\end{array}$ & NA \\
\hline USA 385155085254301 & WELL JPG MW-RS7 & 859.42 & $\begin{array}{l}2.06 \\
4.27\end{array}$ & $\begin{array}{l}857.36 \\
855.15\end{array}$ & $\begin{array}{l}04 / 07 / 2008 \\
07 / 14 / 2008\end{array}$ & $\begin{array}{l}12: 00 \\
12: 50\end{array}$ & $\begin{array}{l}\text { SAIC } \\
\text { SAIC }\end{array}$ & NA \\
\hline USA 385235085252601 & WELL JPG MW-RS8 & 865.03 & $\begin{array}{l}1.12 \\
7.52\end{array}$ & $\begin{array}{l}863.91 \\
857.51\end{array}$ & $\begin{array}{l}04 / 07 / 2008 \\
07 / 14 / 2008\end{array}$ & $\begin{array}{l}10: 52 \\
11: 49\end{array}$ & $\begin{array}{l}\text { SAIC } \\
\text { SAIC }\end{array}$ & NA \\
\hline
\end{tabular}


Table 6. Vertical water-level gradients between paired shallow and deep observation wells in the Pre-Wisconsinan till and in the shallow and deep carbonate units at the Jefferson Proving Ground, southeastern Indiana, 2007-08.

$[\mathrm{mm} / \mathrm{dd} / \mathrm{yyyy}$, month/day/year; -, negative water-level-gradient values indicate downward gradients; positive water-level-gradient values indicate upward gradients]

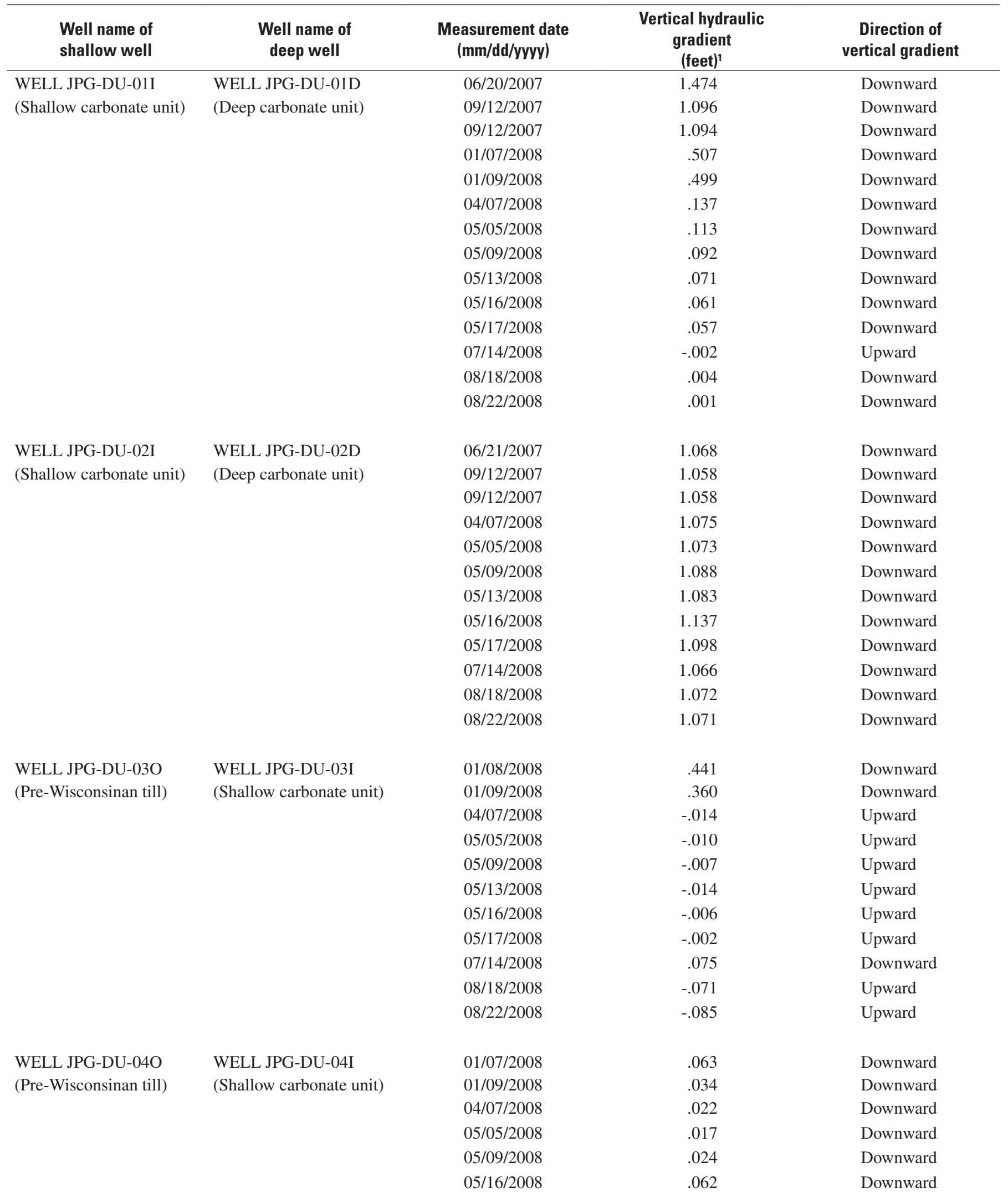


Table 6. Vertical water-level gradients between paired shallow and deep observation wells in the Pre-Wisconsinan till and in the shallow and deep carbonate units at the Jefferson Proving Ground, southeastern Indiana, 2007-08.-Continued

$[\mathrm{mm} / \mathrm{dd} / \mathrm{yyyy}$, month/day/year; -, negative water-level-gradient values indicate downward gradients; positive water-level-gradient values indicate upward gradients]

\begin{tabular}{|c|c|c|c|c|}
\hline $\begin{array}{l}\text { Well name of } \\
\text { shallow well }\end{array}$ & $\begin{array}{l}\text { Well name of } \\
\text { deep well }\end{array}$ & $\begin{array}{c}\text { Measurement date } \\
\text { (mm/dd/yyyy) }\end{array}$ & $\begin{array}{c}\text { Vertical hydraulic } \\
\text { gradient } \\
\text { (feet) }^{1} \\
\end{array}$ & $\begin{array}{c}\text { Direction of } \\
\text { vertical gradient }\end{array}$ \\
\hline \multirow{3}{*}{\multicolumn{2}{|c|}{ WELL JPG-DU-04O_-Continued }} & $05 / 17 / 2008$ & 0.025 & Downward \\
\hline & & 08/18/2008 & .031 & Downward \\
\hline & & $08 / 22 / 2008$ & .029 & Downward \\
\hline \multirow{7}{*}{$\begin{array}{l}\text { WELL JPG-DU-04I } \\
\text { (Shallow carbonate unit) }\end{array}$} & (Deep carbonate unit) & $01 / 09 / 2008$ & 2.030 & Downward \\
\hline & & $04 / 07 / 2008$ & 1.402 & Downward \\
\hline & & 05/05/2008 & 1.463 & Downward \\
\hline & & 05/09/2008 & 1.443 & Downward \\
\hline & & 05/13/2008 & 1.418 & Downward \\
\hline & & 08/18/2008 & 1.172 & Downward \\
\hline & & $08 / 22 / 2008$ & 1.151 & Downward \\
\hline \multirow{7}{*}{$\begin{array}{l}\text { WELL JPG-DU-05I } \\
\text { (Shallow carbonate unit) }\end{array}$} & WELL JPG-DU-05D & $01 / 07 / 2008$ & 1.205 & Downward \\
\hline & (Deep carbonate unit) & $01 / 09 / 2008$ & 1.217 & Downward \\
\hline & & 04/07/2008 & 1.208 & Downward \\
\hline & & $05 / 05 / 2008$ & 1.228 & Downward \\
\hline & & 05/09/2008 & 1.241 & Downward \\
\hline & & $05 / 13 / 2008$ & 1.238 & Downward \\
\hline & & $05 / 16 / 2008$ & 1.252 & Downward \\
\hline \multirow{10}{*}{$\begin{array}{l}\text { WELL JPG-DU-06O } \\
\text { (Pre-Wisconsinan till) }\end{array}$} & (Shallow carbonate unit) & $01 / 09 / 2008$ & .199 & Downward \\
\hline & & $04 / 07 / 2008$ & .125 & Downward \\
\hline & & $05 / 05 / 2008$ & .104 & Downward \\
\hline & & 05/09/2008 & .111 & Downward \\
\hline & & 05/13/2008 & .106 & Downward \\
\hline & & $05 / 16 / 2008$ & .112 & Downward \\
\hline & & $05 / 17 / 2008$ & .115 & Downward \\
\hline & & $07 / 14 / 2008$ & .115 & Downward \\
\hline & & 08/18/2008 & .125 & Downward \\
\hline & & $08 / 22 / 2008$ & .124 & Downward \\
\hline \multirow{5}{*}{$\begin{array}{l}\text { WELL JPG-DU-06I } \\
\text { (Shallow carbonate unit) }\end{array}$} & WELL JPG-DU-06D & $06 / 21 / 2007$ & .064 & Downward \\
\hline & (Deep carbonate unit) & $07 / 18 / 2007$ & .535 & Downward \\
\hline & & 09/11/2007 & .186 & Downward \\
\hline & & $09 / 12 / 2007$ & .187 & Downward \\
\hline & & $09 / 12 / 2007$ & .183 & Downward \\
\hline
\end{tabular}


Table 6. Vertical water-level gradients between paired shallow and deep observation wells in the Pre-Wisconsinan till and in the shallow and deep carbonate units at the Jefferson Proving Ground, southeastern Indiana, 2007-08._Continued

$[\mathrm{mm} / \mathrm{dd} / \mathrm{yyyy}$, month/day/year; -, negative water-level-gradient values indicate downward gradients; positive water-level-gradient values indicate upward gradients]

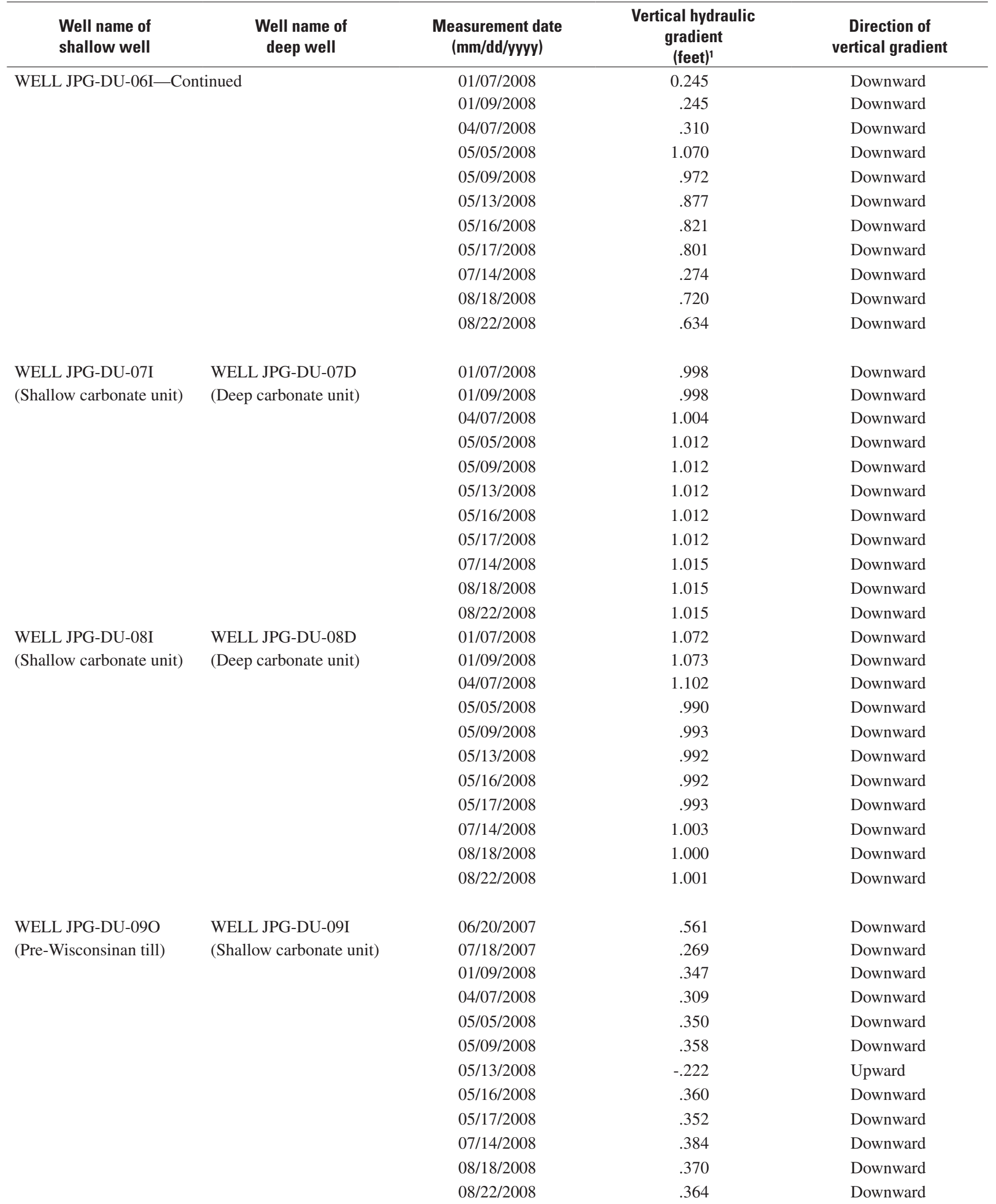


Table 6. Vertical water-level gradients between paired shallow and deep observation wells in the Pre-Wisconsinan till and in the shallow and deep carbonate units at the Jefferson Proving Ground, southeastern Indiana, 2007-08._Continued

$[\mathrm{mm} / \mathrm{dd} / \mathrm{yyyy}$, month/day/year; -, negative water-level-gradient values indicate downward gradients; positive water-level-gradient values indicate upward gradients]

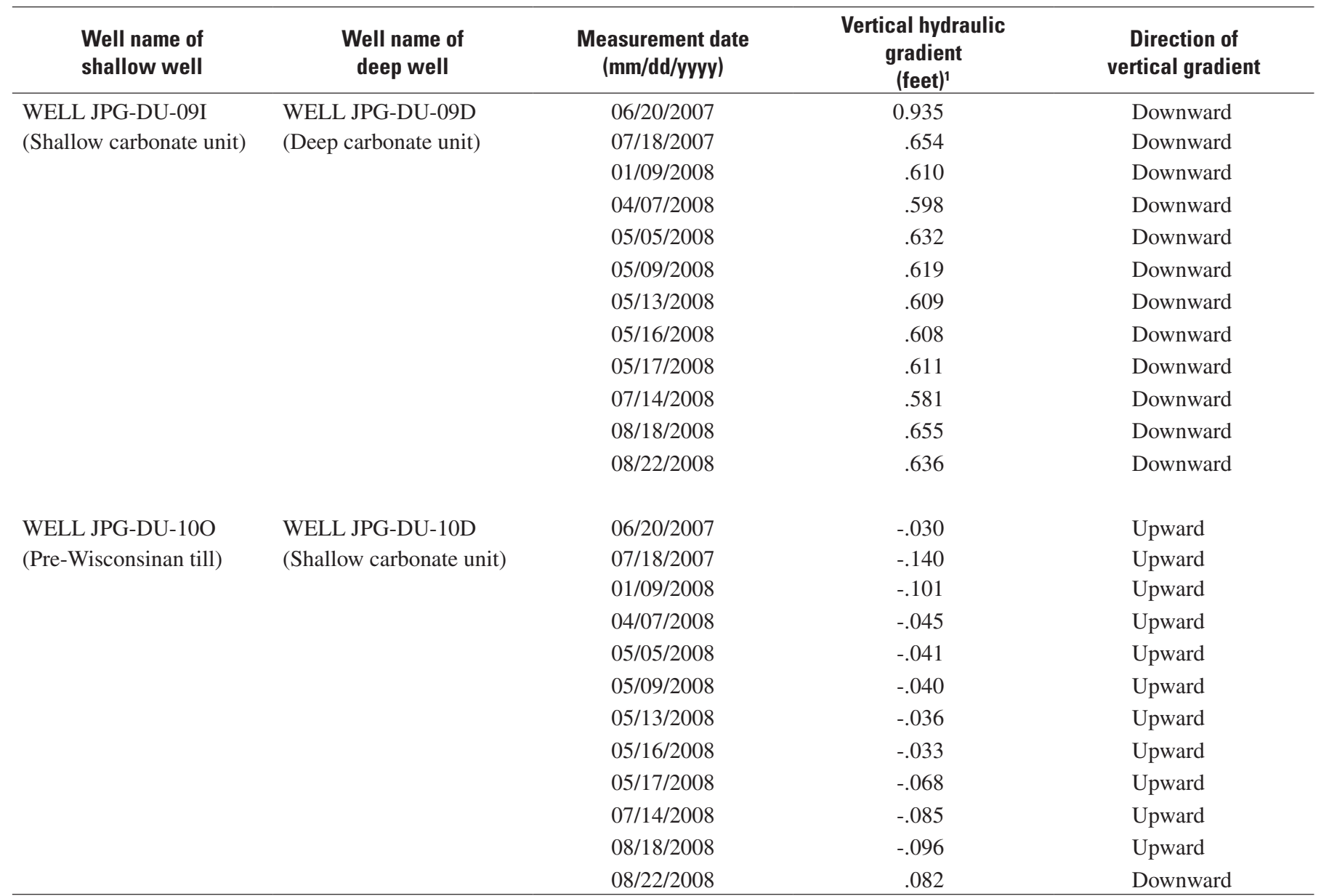

\footnotetext{
${ }^{1}$ Vertical gradients were computed between water levels in wells, using the formula vertical gradient $=(\mathrm{WLs}-\mathrm{WLd}) /(\mathrm{ALTs}-\mathrm{ALTd})$

WLs is the water-level altitude in the shallow well or the surface-water stage;

WLd is the water-level altitude in the deep well;

ALTs is one of the following values. When the water table was in the screened interval in the shallow well, ALTs was the altitude of the midpoint between the water-table altitude and the altitude of the base of the shallow well screen. When the water table was above the screened interval of the shallow well, ALTs was the altitude of the midpoint between the top and base of the shallow well screen; and

ALTd is one of the following values. When the water table was in the screened interval in the deep well, ALTd was the altitude of the midpoint between the water-table altitude and the altitude of the base of the deep well screen. When the water table was above the screened interval of the deep well, ALTd was the altitude of the midpoint between the top and base of the deep well screen.
} 


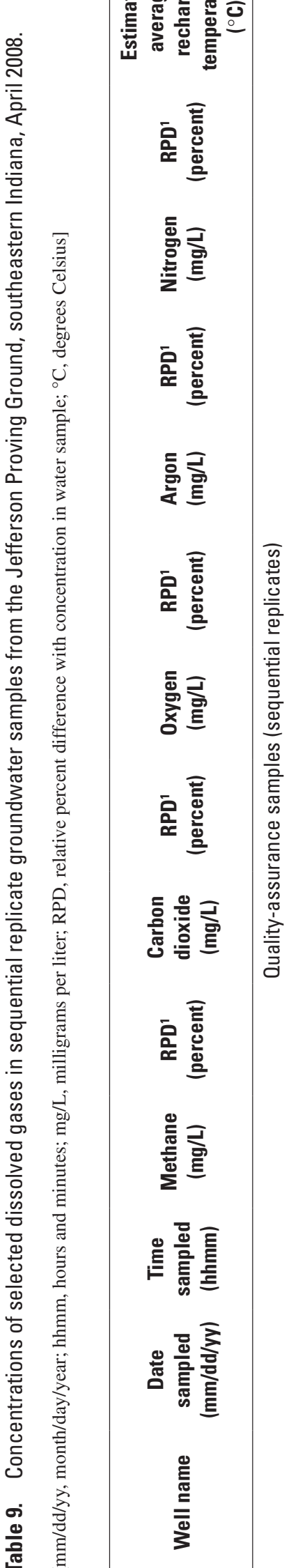

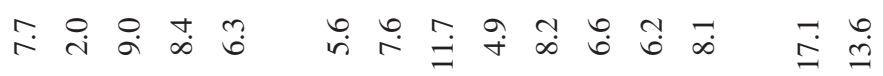

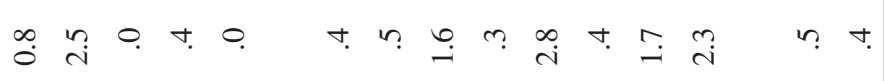

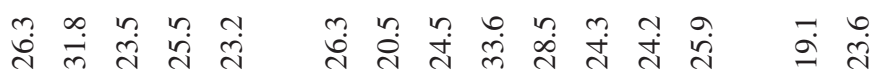

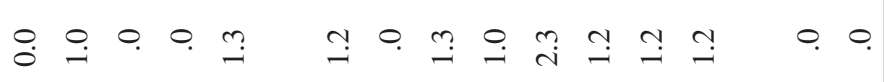

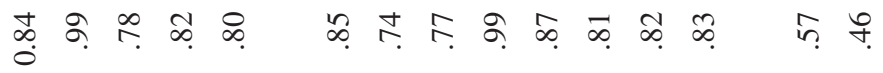

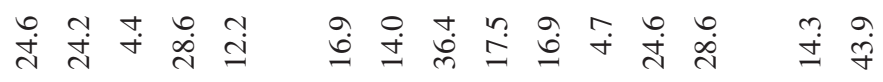

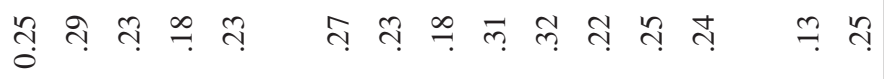

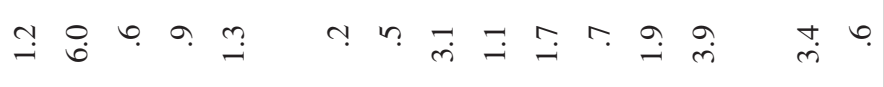

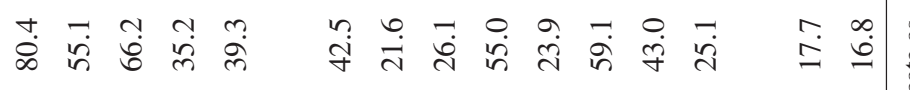

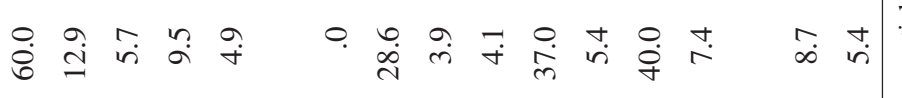

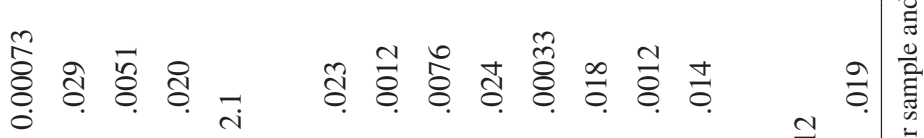

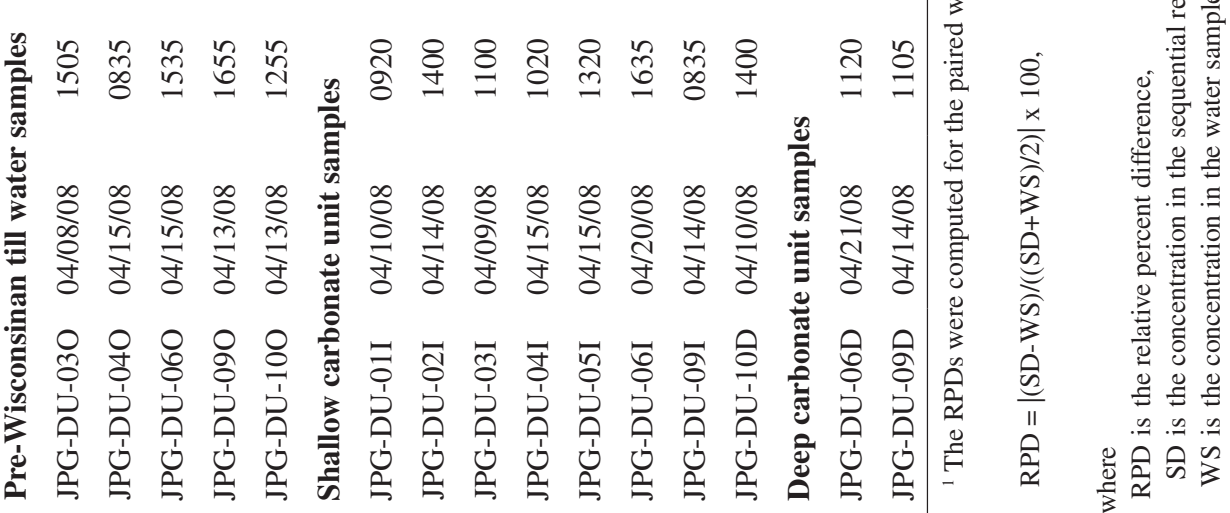




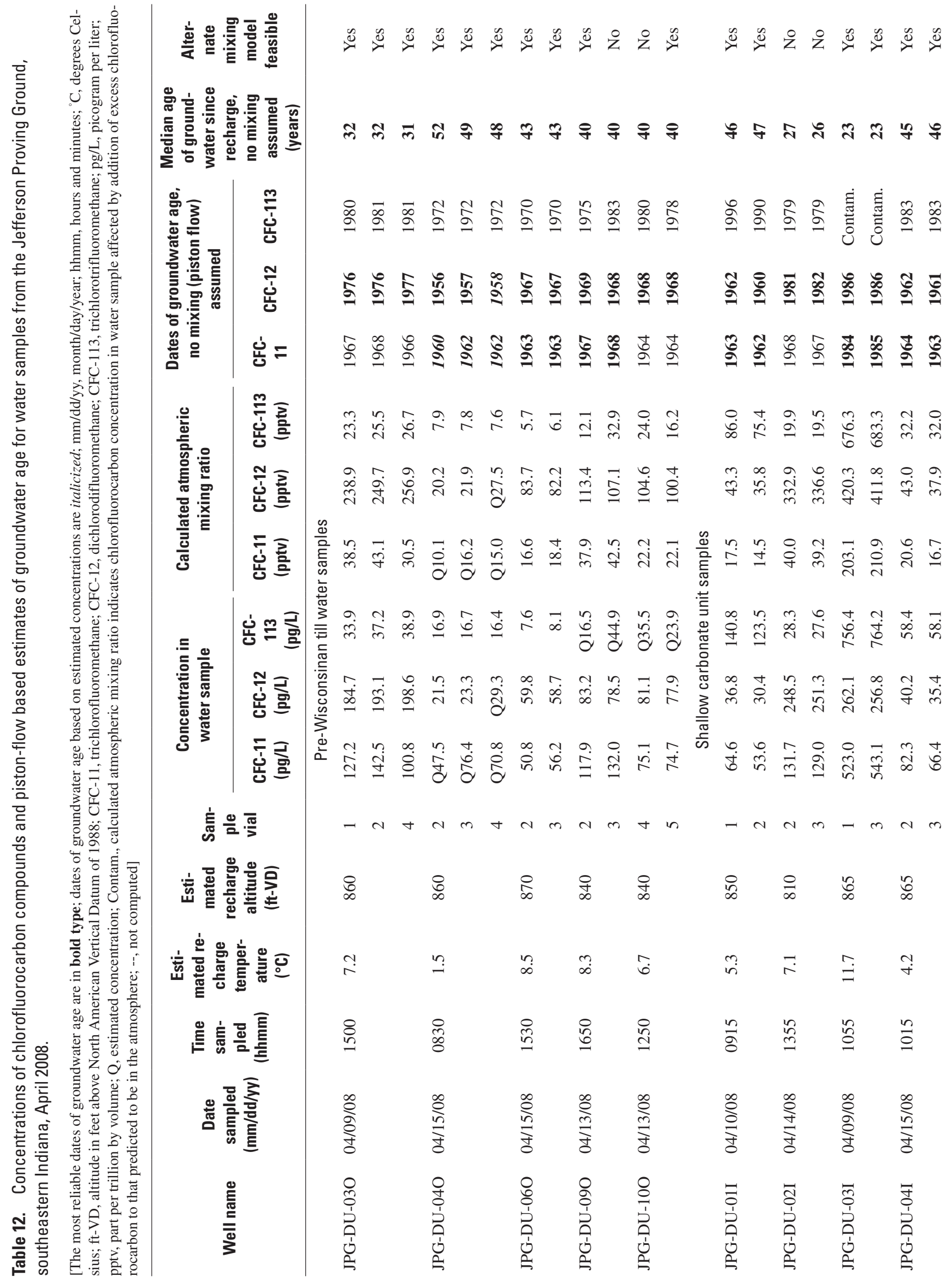




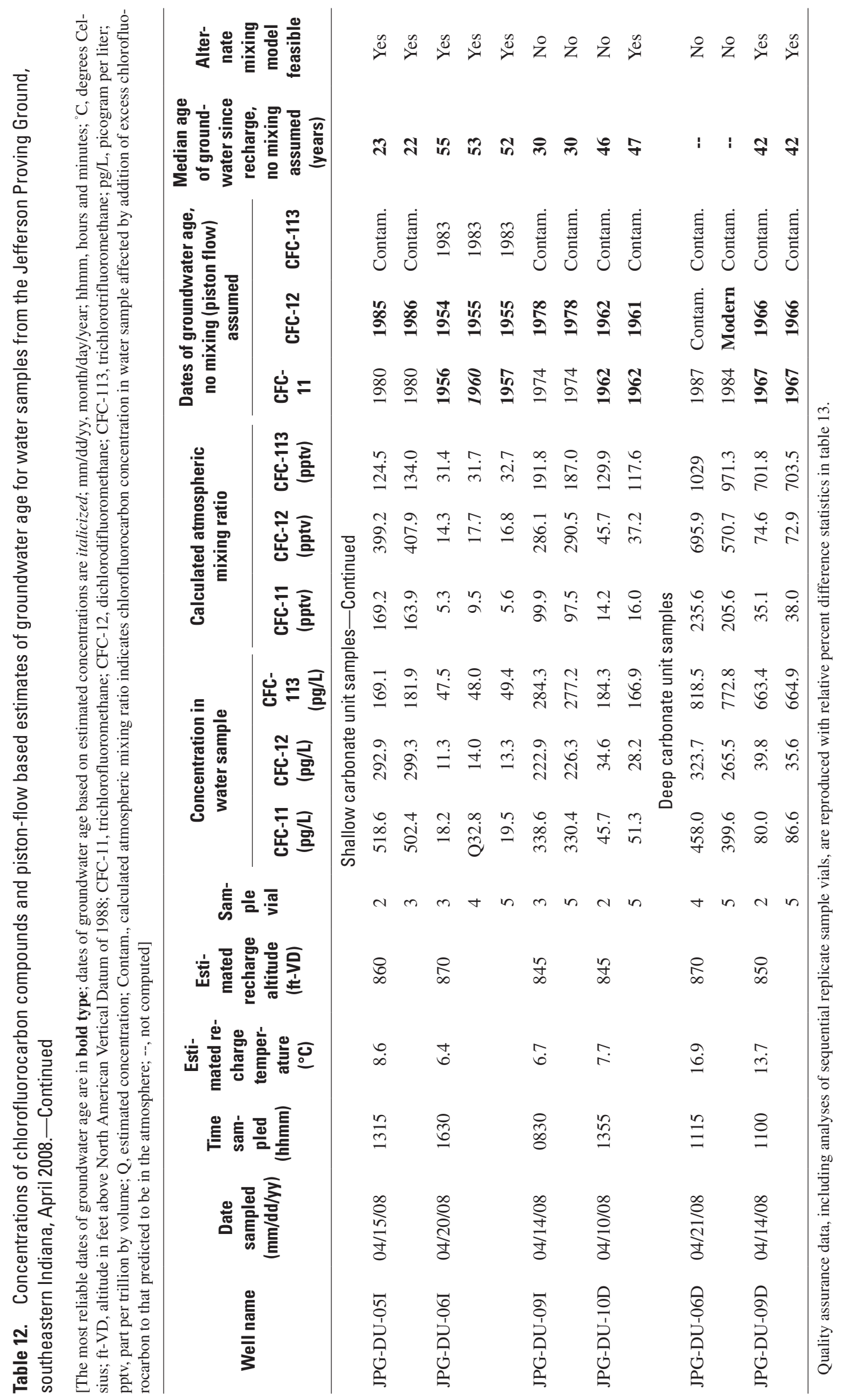




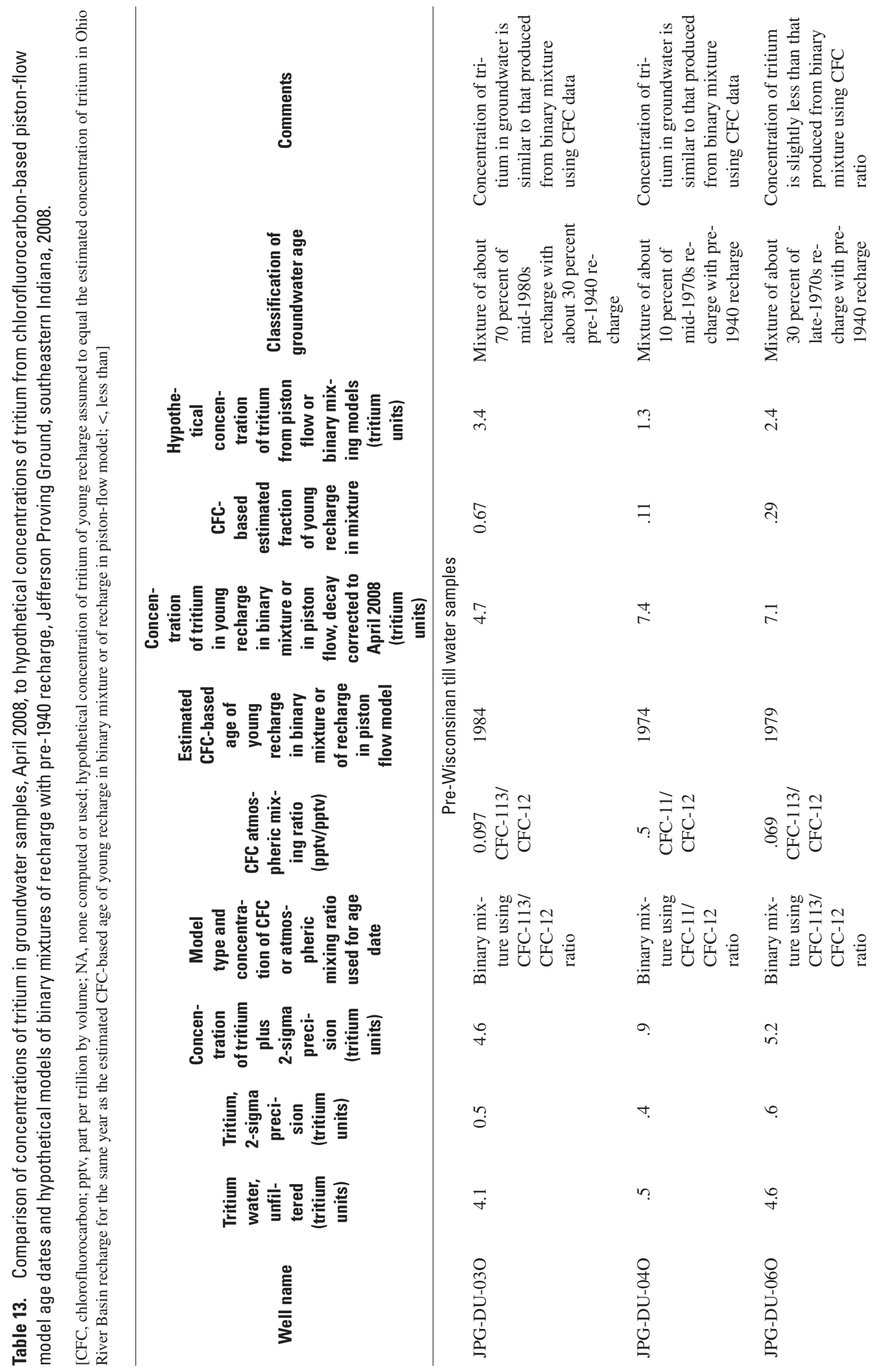




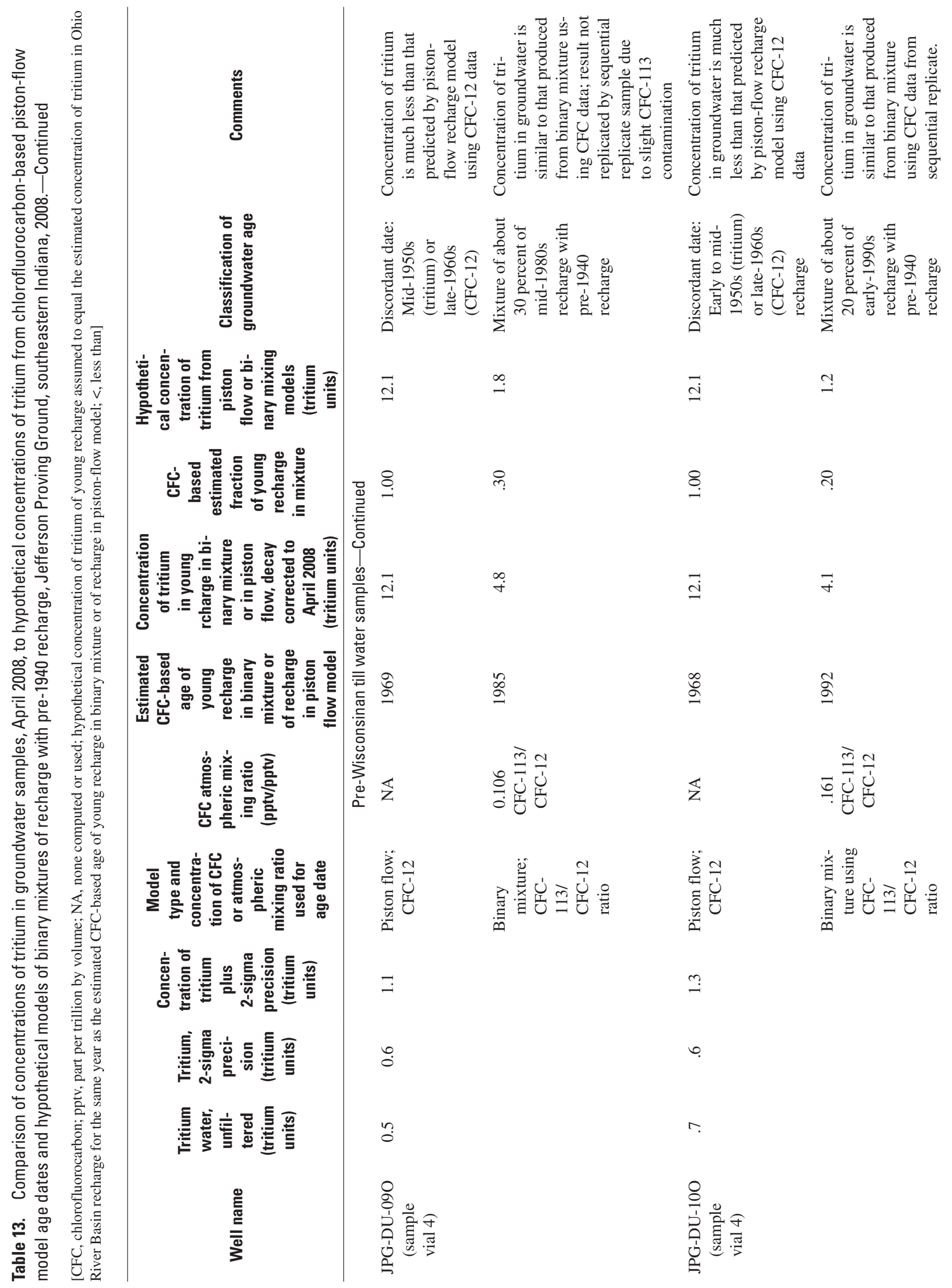




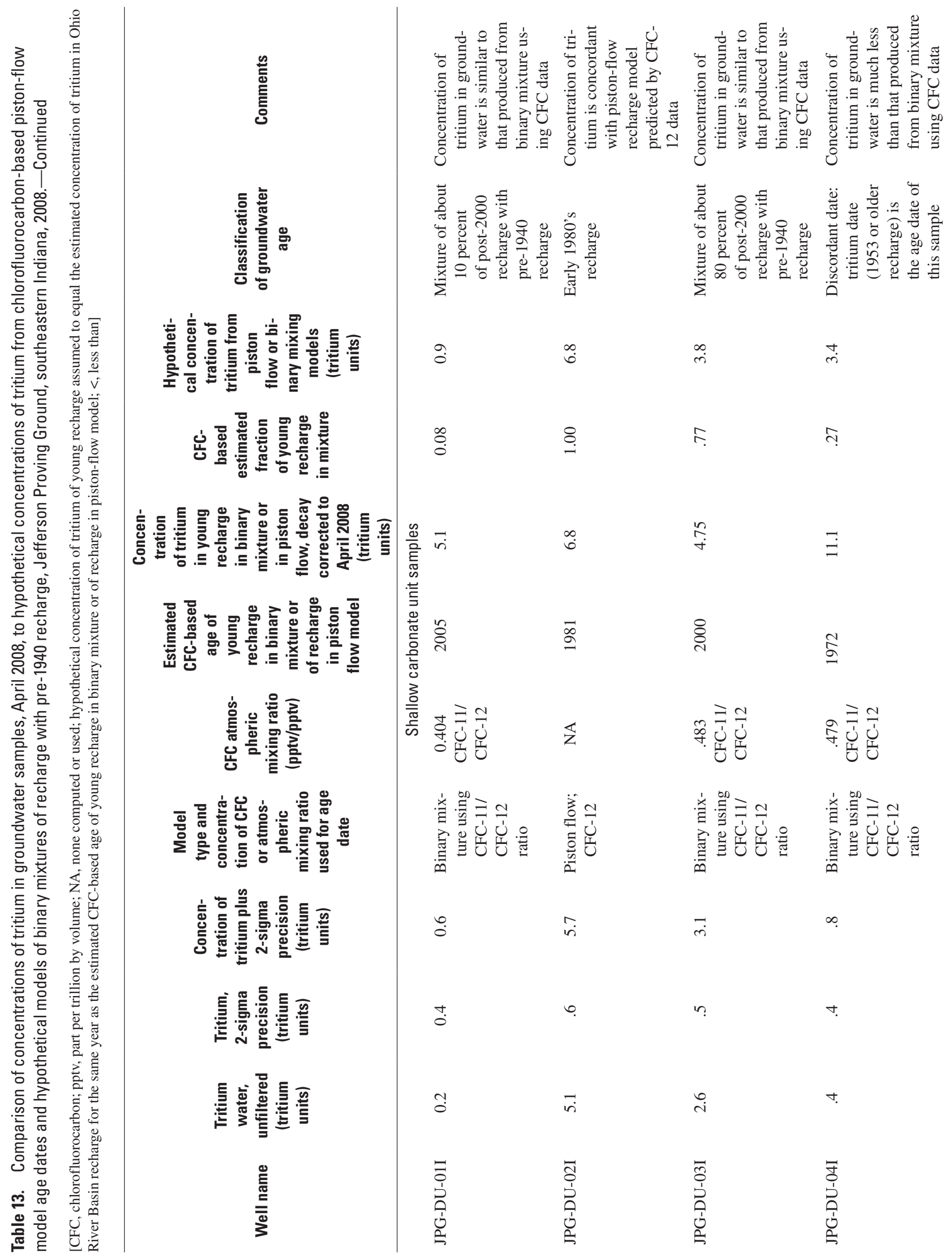




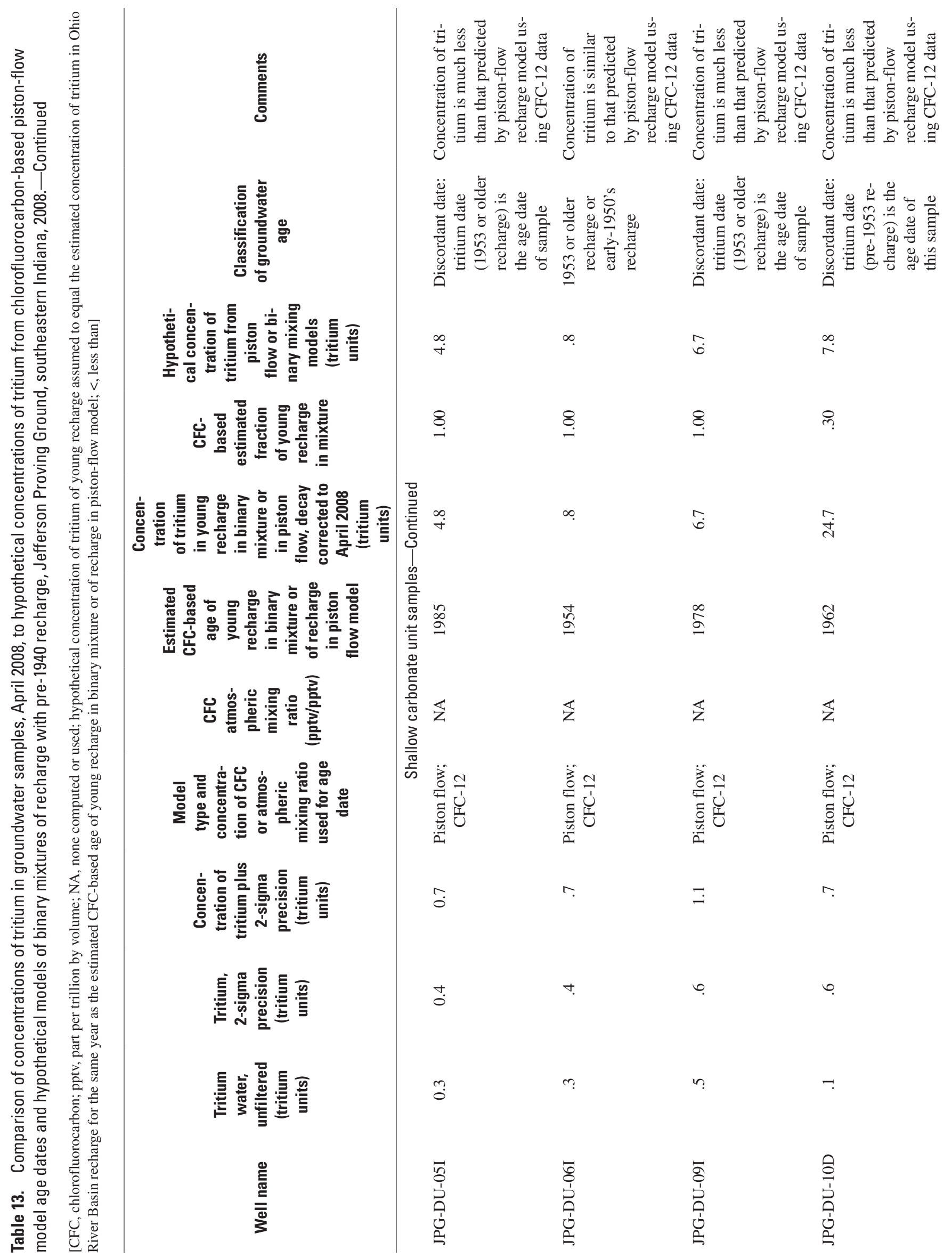




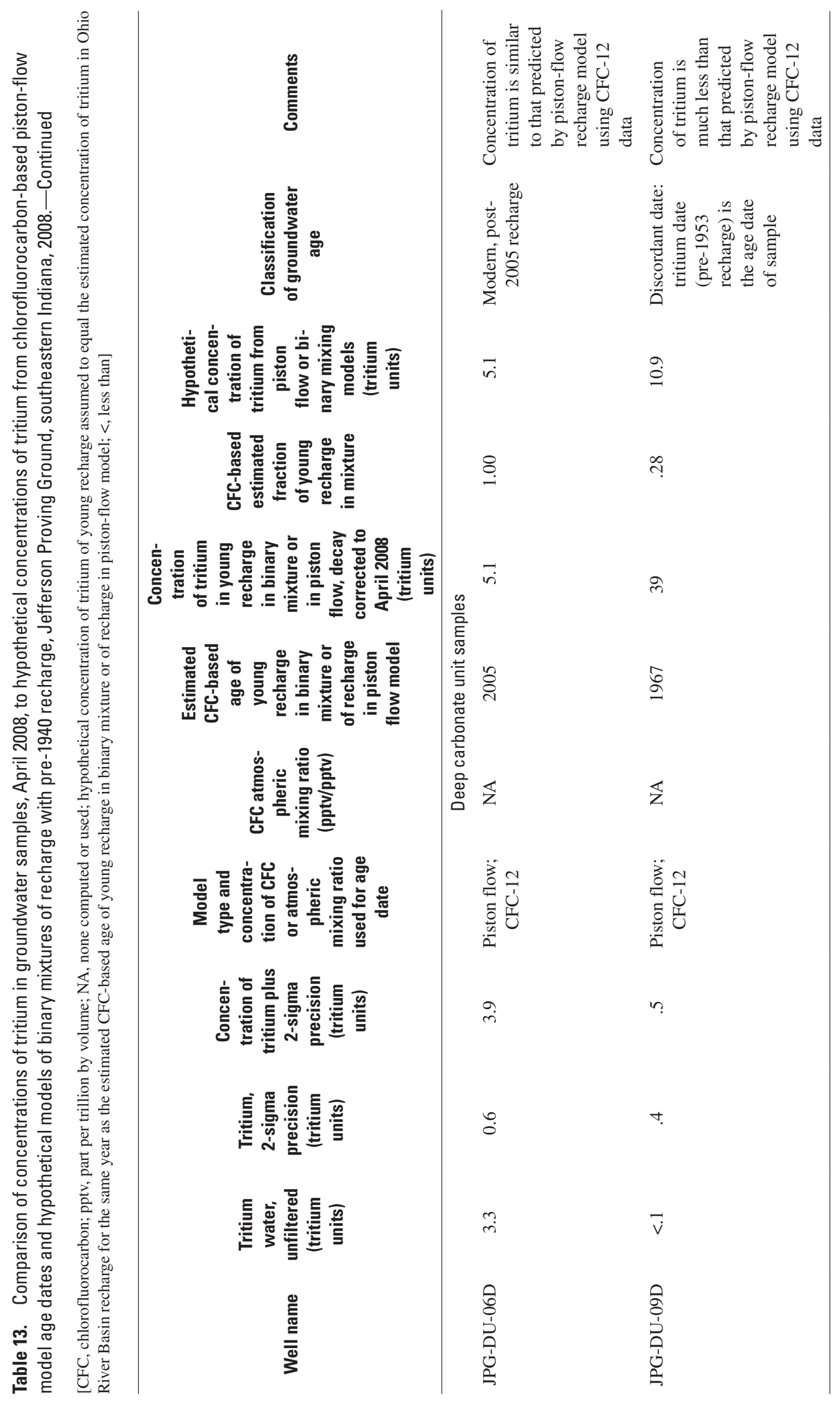


Table 15. Concentrations of chlorofluorocarbon compounds in sequential replicate groundwater samples from the Jefferson Proving Ground, southeastern Indiana, April 2008.

[The most reliable dates of groundwater age are in bold; mm/dd/yy, month/day/year; hhmm, hours and minutes; CFC-11, trichlorofluoromethane; pg/L, picogram per liter; RPD, relative percent difference; CFC-12, dichlorodifluoromethane; CFC-113, trichlorotrifluoromethane]

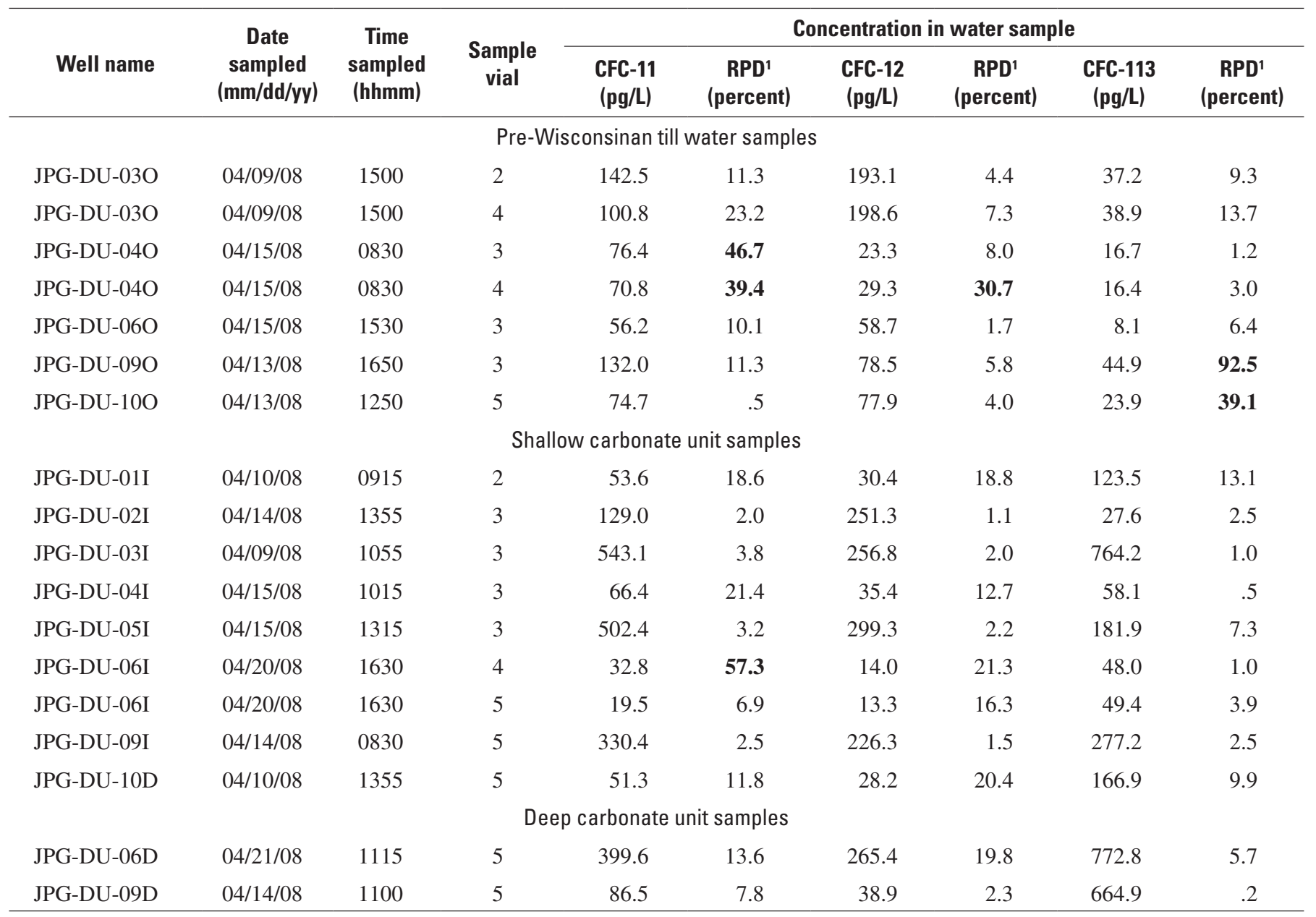

${ }^{1}$ The RPDs were computed for the paired water sample (table 10) and sequential replicate as $\mathrm{RPD}=|(\mathrm{SD}-\mathrm{WS}) /((\mathrm{SD}+\mathrm{WS}) / 2)| \times 100$,

where

RPD is the relative percent difference,

$\mathrm{SD}$ is the concentration in the sequential replicate, and

WS is the concentration in the water sample. 
